\title{
EFEITOS DE DIFERENTES SUBSTRATOS NA PRODUÇÃO DA ESPÉCIE Aechmea fasciata (LINDLEY) BAKER EM VASOS
}

\section{SHOEY KANASHIRO \\ Engenheiro Agrônomo}

Orientador: Prof. Dr. KEIGO MINAMI

Dissertação apresentada à Escola Superior de Agricultura "Luiz de Queiroz", Universidade de São Paulo, para obtenção do título de Mestre em Agronomia, Área de Concentração: Fitotecnia

\section{PIRACICABA}

Estado de São Paulo - Brasil

Dezembro - 1999 
Dados Internacionais de Catalogação na Publicação (CIP) DIVISĀO DE BIBLIOTECA E DOCUMENTAÇĀO - Campus "Luiz de Queiroz"/USP

Kanashiro, Shoey

Efeitos de diferentes substratos na produçāo da espécie Aechmea fasciaca

(Lindley) Baker em vasos / Shoey Kanashiro. - - Piracicaba, 1999.

79 p.

Dissertação (mestrado) - - Escola Superior de Agricultura Luiz de Queiroz, 1999. Bibliografia.

1. Bromélia 2. Bromelíaceae 3. Cultivo em vaso 4. Planta ornamental 5. Substrato I. Título

CDD 635.93422 


\section{ERRATA}

Pág. xiv, $1^{\text {o. }}$ parágrafo, $1 \mathrm{a}$. linha, onde se lê objective, leia-se aim.

Pág. xiv: acrescentar (fern tree fibre) após todas as palavras xaxim.

Pág. 75, após o $5^{\circ}$ parágrafo, acrescentar:

FONTENO, W.C. Types and physical/chemical properties. In: Reed, D.W. A grower's guide to water, media, and nutrition for greenhouse crops. Batavia: Ball Publishing, 1996. cap. 5, p. 93-122. 
Aos meus pais,

Seiichi e Masa,

dedico.

À Teresa, minha esposa,

à Marta e Renato, meus filhos, e à Dona Ana

ofereço. 


\section{AGRADECIMENTOS}

\section{A Deus;}

Ao Professor Dr. Keigo Minami pela orientação, amizade e apoio no decorrer do curso e da fase experimental do trabalho;

À Escola Superior de Agricultura "Luiz de Queiroz" pela oportunidade de aperfeiçoamento;

Ao Instituto de Botânica por permitir o afastamento para freqüentar o curso de pós graduação;

À Teresa Jocys, minha esposa, pela colaboração na implantação, condução e coleta de dados do experimento, compreensão e apoio nos momentos mais críticos;

Aos colegas Walter Geremias Rodriguez Robles, Antonio Carlos Carvalho Antonini, Valéria Aparecida Modolo, Regma Simone Xavier Caetano, Ernesto J.R. Rodrigues e Luis Enrique Robledo Ortigoza pela amizade e colaboração durante o curso;

Aos funcionários e estagiários do Departamento de Produção Vegetal da ESALQ pela ajuda na condução do experimento e coleta de dados;

Aos pesquisadores científicos da Seção de Ornamentais pelo apoio e sugestões no decorrer do curso;

Aos funcionários da Seção de Omamentais do Instituto de Botânica da Secretaria do Meio Ambiente pela colaboração, especialmente às Senhoras Maria da Conceição Maciel Oliveira, Luzia Rodrigues Scarpeta e Eunice Neves pela ajuda na coleta de dados;

Ao pesquisador científico Dr. Cláudio José Barbedo do Instituto de Botânica da Secretaria do Meio Ambiente pelas valiosas sugestões;

Às pesquisadoras científicas Dra. Marisa Domingos e Dra. Márcia Inês Martin Silveira Lopes da Seção de Ecologia do Instituto de Botânica da Secretaria do Meio Ambiente pelo empréstimo de equipamentos;

À ilustradora botânica Srta. Maria Cecília Tomasi do Instituto de Botânica da Secretaria do Meio Ambiente e à Prof ${ }^{-}$. Ana Maria Villela Alvarez Martinez pelos desenhos; 
Ao Prof. Dr. Carlos Tadeu dos Santos Dias do Departamento de Ciência Exatas pelo auxilio no planejamento e análise dos dados e ao Prof. Ricardo Ferraz de Oliveira do Departamento de Ciências Biológicas pelo empréstimo de equipamento;

Ao Dr. Rolf E. Zornig, proprietário do Rolf Bromélias, pelas sugestões nos tratos culturais indispensáveis à condução da cultura da bromélia Aechmea fasciata;

À Eucatex Química e Mineradora Ltda pelo fornecimento da turfa e perlita utilizados no experimento;

Ao Artesanato Coxim Ltda pela doação do coxim, especialmente na pessoa do Prof. Augusto Burle, proprietário da empresa e

Ao CNPq (Conselho Nacional de Desenvolvimento Científico e Tecnológico) pela concessão da bolsa de estudo. 


\section{SUMÁRIO}

Página

LISTA DE FIGURAS............................................................................................................ vii

LISTA DE TABELAS................................................................................................... ix

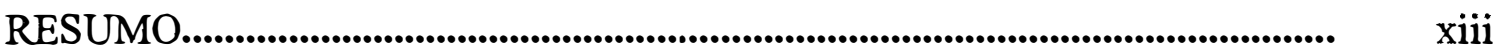

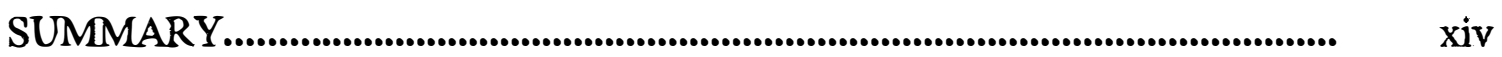

1. INTRODUÇÃO........................................................................................................... 01

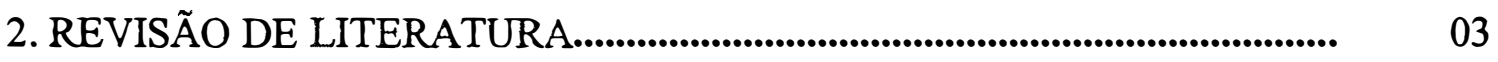

2.1. Aechmea fasciata..................................................................................................... 03

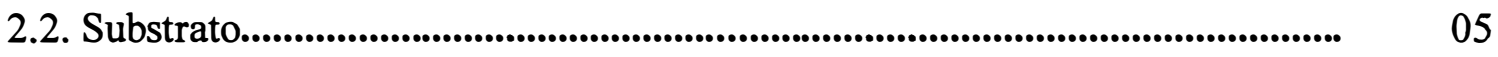

2.2.1. Considerações gerais....................................................................................... 05

2.2.2. Características físicas......................................................................................... 06

2.2.3. Características químicas................................................................................... 07

2.2.4. Substratos para bromeliáceas.............................................................................. 08

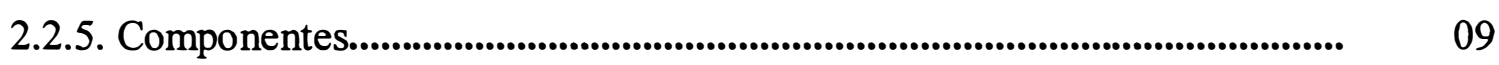

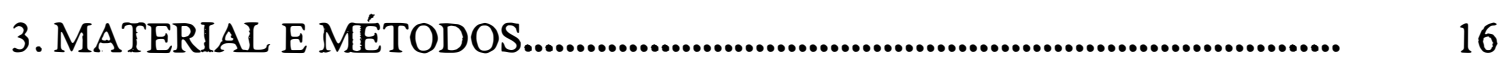

3.1. Instalação do experimento................................................................................. 16

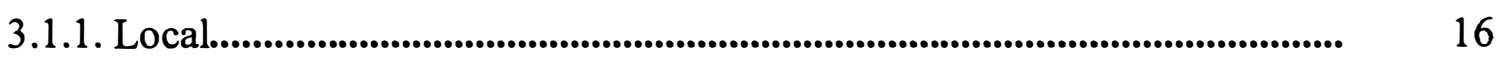

3.1.2. Mudas............................................................................................................ 17

3.1.3. Recipientes para cultivo................................................................................... 17

3.1.4. Componentes dos substratos........................................................................ 18

3.1.5. Dados meteorológicos............................................................................................ 18

3.2. Condução do experimento.......................................................................................... 19

3.2.1. Espaçamento................................................................................................... 19

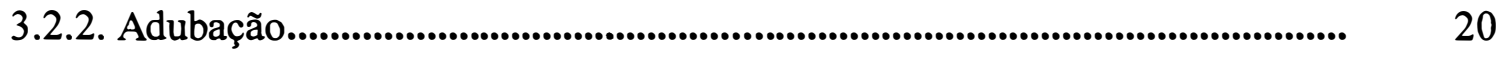

3.2.3. Irrigação................................................................................................................ 20

3.2.4. Controle de pragas e doenças............................................................................ 21

*3.2.5. Indução floral........................................................................................................... 21 
Página

3.3. Avaliaçõ̃es.............................................................................................................. 22

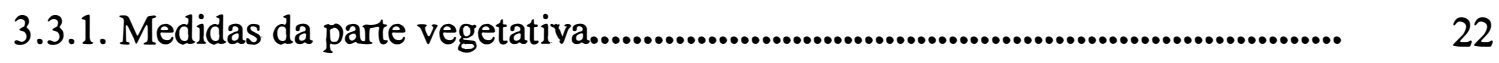

3.3.2. Medidas da inflorescência.................................................................................. 24

3.3.3. Área foliar e massa seca...................................................................................... 26

3.3.4. Fixação da planta no substrato em vaso............................................................. 29

3.3.5. Qualidade comercial.................................................................................... 29

3.4. Constituição dos tratamentos, delineamento experimental e análise

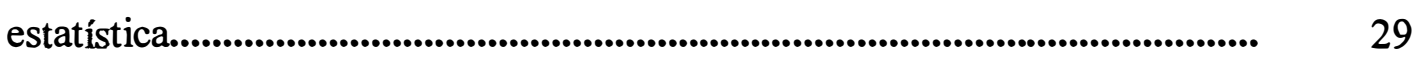

4. RESULTADOS E DISCUSSÃO.................................................................... 33

4.1. Análise física e química dos substratos................................................................. 33

4.1.1. Análise fisica.................................................................................................... 33

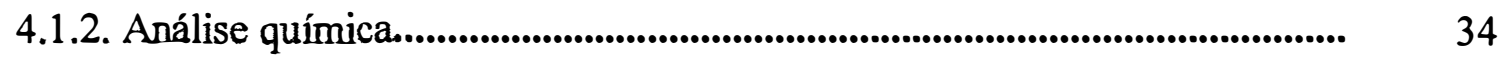

4.2. Variáveis analisadas durante o crescimento...................................................... 34

4.2.1. Altura e maior diâmetro da planta e largura da terceira folha........................ 34

4.2.2. Número de folhas e diâmetro do colo................................................................. 47

4.3. Variáveis analisadas no florescimento................................................................... 53

4.3.1. Parte aérea vegetativa..................................................................................... 53

4.3.2. Medidas da inflorescência..................................................................................... 56

4.3.3. Massa seca.................................................................................................. 59

4.3.4. Qualidade comercial e fixação da planta no substrato em vaso.................... $\quad 65$

5. CONCLUSÕES........................................................................................................ 73

REFERÊNCIAS BIBLIOGRÁFICAS.......................................................................... $\quad 74$ 


\section{LISTA DE FIGURAS}

Página

01 Desenho esquemático mostrando o critério adotado para a medida do maior diâmetro (MD) e folha com maior largura (L) da espécie $A$. fasciata Lindley (Baker), ESALQ-USP, Piracicaba, SP...........................

02 Desenho esquemático mostrando o critério adotado para a medida do maior diâmetro $(M)$ e comprimento da inflorescência $(C)$ e destaque de um ramo da inflorescência (R) da espécie $A$. fasciata Lindley (Baker), ESALQ-USP, Piracicaba, SP.................................................................................

03 Desenho esquemático com a identificação do caule (C), escapo floral (EF) e inflorescência (I) da espécie $A$. fasciata Lindley (Baker), ESALQ-USP, Piracicaba, SP.................................................................................

04 Médias observadas e funções ajustadas para a variável altura da planta, em função dos tempos dentro dos tratamentos, na espécie $A$. fasciata Lindley (Baker), ESALQ-USP, Piracicaba, SP

05 Médias observadas e funções ajustadas para a variável maior diâmetro da planta, em função dos tempos dentro dos tratamentos, na espécie $A$. fasciata Lindley (Baker), ESALQ-USP, Piracicaba, SP

06 Médias observadas e funções ajustadas para a variável largura da terceira folha, em função dos tempos dentro dos tratamentos, na espécie A. fasciata Lindley (Baker), ESALQ-USP, Piracicaba, SP 


\section{Página}

07 Médias observadas e funções ajustadas para a variável número de folhas, em função dos tempos para cada tratamento, na espécie $A$. fasciata Lindley (Baker), ESALQ-USP, Piracicaba, SP..............................

08 Médias observadas e funções ajustadas para a variável diâmetro do colo, em função dos tempos para cada tratamento, na espécie $A$. fasciata Lindley (Baker), ESALQ-USP, Piracicaba, SP.

09 Espécimes de $A$. fasciata testadas nos substratos formulados com xaxim, nas proporções 2:7:1 (13), 5:4:1 (14) e 8:1:1 (15), ESALQ-USP, Piracicaba, SP

10 Espécimes de $A$. fasciata testadas nos substratos formulados com casca de Pinus, nas proporções 2:7:1 (1), 5:4:1 (2) e 8:1:1 (3). ESALQ-USP,

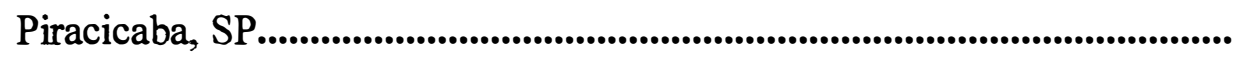

11 Espécimes de $A$. fasciata testadas nos substratos formulados com casca de Pinus (1), casca de Eucalyptus (4), coxim (7), fibra de coco (10) e xaxim (13), na proporção 2:7:1, ESALQ-USP, Piracicaba, SP.................. 


\section{LISTA DE TABELAS}

Página

1 Médias mensais de temperatura e umidade relativa do ar observadas entre julho de 1997 a outubro de 1998, medidas pelo posto agrometeorológico do Departamento de Ciências Exatas da ESALQ-

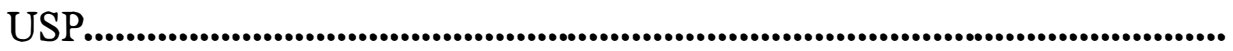

2 Composição e proporção dos diferentes substratos utilizados no cultivo de $A$. fasciata em vaso, ESALQ-USP, Piracicaba, SP...............................

3 Características físicas dos substratos utilizados no experimento com a espécie $A$. fasciata Lindley (Baker), ESALQ-USP, Piracicaba, SP...........

4 Análise química dos substratos contendo casca de Pinus, casca de Eucalyptus e coxim, misturados com turfa e perlita, nas proporções 2:7:1, 5:4:1 e 8:1:1, utilizados no experimento com a espécie $A$. fasciata Lindley (Baker), ESALQ-USP, Piracicaba, SP.

5 Análise química dos substratos contendo fibra de coco ou xaxim, misturados com turfa e perlita, nas proporções 2:7:1, 5:4:1 e 8:1:1, utilizados no experimento com a espécie $A$. fasciata Lindley (Baker), ESALQ-USP, Piracicaba, SP

6 Análise de variância e teste $\mathrm{F}$ para as variáveis altura, maior diâmetro e largura da terceira folha da espécie A. fasciata Lindley (Baker), ESALQ-USP, Piracicaba, SP. 
7 Médias observadas para a variável altura da planta, em função dos tratamentos dentro de cada tempo, da espécie $A$. fasciata Lindley (Baker), ESALQ-USP, Piracicaba, SP.

8 Médias observadas para a variável maior diâmetro da planta, em função dos tratamentos dentro de cada tempo, da espécie $A$. fasciata Lindley (Baker), ESALQ-USP, Piracicaba, SP.

9 Médias observadas para a variável largura da terceira folha, em função dos tratamentos dentro de cada tempo, da espécie $A$. fasciata Lindley (Baker), ESALQ-USP, Piracicaba, SP

10 Análise de variância e teste $\mathrm{F}$ para as variáveis número de folhas $\mathrm{e}$ diâmetro do colo da espécie $A$. fasciata Lindley (Baker), ESALQ-USP, Piracicaba, SP

11 Médias observadas para a variável número de folhas, em função dos tratamentos dentro de cada tempo, da espécie $A$. fasciata Lindley (Baker), ESALQ-USP, Piracicaba, SP......................................................

12 Médias observadas para a variável diâmetro do colo, em função dos tratamentos dentro de cada tempo, da espécie $A$. fasciata Lindley (Baker), ESALQ-USP, Piracicaba, SP

13 Análise de variância e teste $F$ para as variáveis aérea da planta, considerando-se folha com maior largura, diâmetro da planta e área foliar da espécie $A$. fasciata Lindley (Baker), ESALQ-USP, Piracicaba, SP. 
14 Médias da folha com maior largura, diâmetro da planta e área foliar da espécie $A$. fasciata Lindley (Baker), ESALQ-USP, Piracicaba, SP...........

15 Análise de variância e teste $\mathrm{F}$ para as variáveis da inflorescência, considerando-se o maior diâmetro, altura e número de ramos da inflorescência da espécie $A$. fasciata Lindley (Baker), ESALQ-USP, Piracicaba, SP...................................................................................................

16 Médias do maior diâmetro, comprimento e número de ramos da inflorescência da espécie $A$. fasciata Lindley (Baker), ESALQ-USP, Piracicaba, SP...............................................................................................................

17 Análise de variância e teste $F$ para as variáveis de massa seca, considerando-se a folha, raiz, inflorescência, escapo floral, caule, total da massa e área foliar da espécie $A$. fasciata Lindley (Baker), ESALQUSP, Piracicaba, SP.................................................................................

18 Médias da massa seca da folha, massa seca da raiz, massa seca da inflorescência, massa seca da haste, massa seca do caule e massa seca total da espécie A. fasciata Lindley (Baker), ESALQ-USP, Piracicaba, SP

19 Freqüências observadas de notas 1, 2 e 3, e suas respectivas porcentagens na variável qualidade comercial da espécie $A$. fasciata Lindley (Baker), ESALQ-USP, Piracicaba, SP........................................ 
20 Resultados do teste de $\chi^{2}$ para variável qualidade comercial, comparando os tratamentos dois a dois, da espécie $A$. fasciata Lindley (Baker), ESALQ-USP, Piracicaba, SP..............................................................

21 Freqüências observadas de notas 1,2 e 3 , e suas respectivas porcentagens na variável fixação da planta no substrato em vaso da espécie $A$. fasciata Lindley (Baker), ESALQ-USP, Piracicaba, SP...........

22 Resultados do teste de $\chi^{2}$ para variável notas de fixação da planta no vaso, comparando os ratamentos dois a dois, da espécie $A$. fasciata Lindley (Baker), ESALQ-USP, Piracicaba, SP.................................................. 


\title{
EFEITOS DE DIFERENTES SUBSTRATOS NA PRODUÇÃO DA ESPÉCIE Aechmea fasciata (LINDLEY) BAKER EM VASOS
}

\author{
Autor: SHOEY KANASHIRO \\ Orientador: Prof. Dr. KEIGO MINAMI
}

\section{RESUMO}

O presente trabalho teve como objetivo encontrar substratos alternativos adequados para o cultivo da bromélia Aechmea fasciata (Lindley) Baker que poderiam substituir com eficiência as misturas formulados com xaxim, Dicksonia sellowiana (Presl.) Hook. Para tanto, foram testados os substratos contendo casca de Pinus, casca de Eucalyptus, coxim, fibra de coco ou xaxim, misturados com turfa e perlita nas proporções $2: 7: 1,5: 4: 1$ e $8: 1: 1$.

O experimento foi realizado em condições de estufa com cobertura de polietileno e sombreadas com sombrite $70 \%$, em Piracicaba, SP. As bromélias foram cultivadas durante 435 dias, até o início do florescimento, estágio em que estão aptas para a comercialização.

Nas condições em que foi conduzido o experimento, concluiu-se que os substratos formulados com xaxim ou casca de Pinus, nas proporções 2:7:1, 5:4:1 e 8:1:1, e casca de Eucalyptus, fibra de coco ou coxim, na proporção 2:7:1, foram as misturas que apresentaram os melhores resultados.

Os substratos formulados com casca de Eucalyptus, fibra de coco ou coxim, na proporção 8:1:1, apresentaram os piores resultados.

Casca de Pinus, nas proporções 2:7:1, 5:4:1 e 8:1:1, casca de Eucalyptus, fibra de coco ou coxim, na proporção $2: 7: 1$, são os substratos alternativos que poderiam substituir com eficácia as misturas que contém xaxim, nas proporções 2:7:1, 5:4:1 e $8: 1: 1$. 


\title{
EFFECTS OF DIFFERENT SUBSTRATES ON THE PRODUCTION OF Aechmea fasciata (LINDLEY) BAKER IN CONTAINERS
}

\author{
Author: SHOEY KANASHIRO \\ Adviser: Prof. Dr. KEIGO MINAMI
}

\section{SUMMARY}

The objective of this study was to find out appropriate alternative substrates for the cultivation of the bromeliad Aechmea fasciata (Lindley) Baker in order to substitute with efficiency the formulated mixtures with "xaxim", Dicksonia sellowiana (Presl.) Hook. The substrates containing Pinus bark, Eucalyptus bark, "coxim", coir or "xaxim", mixed with peat and perlite, in the proportions 2:7:1, 5:4:1 and 8:1:1, were tested.

The experiment was conducted in a greenhouse covered with polyethylene and shaded with shadecloth $70 \%$, in Piracicaba, State of São Paulo, Brazil. The bromeliads were cultivated during 435 days, until the beginning of the flowering, when they are suitable for the commercialization.

Under the experimental conditions used, it was concluded that the substrates formulated with "xaxim" or Pinus bark, in the proportions 2:7:1, 5:4:1 and 8:1:1, and Eucalyptus bark, coir or coxim, in the proportion 2:7:1, showed the best results.

However, the substrates formulated with Eucalyptus bark, coir or "coxim", in the proportion 8:1:1, showed the worst results.

Thus, Pinus bark, in the proportions 2:7:1, 5:4:1 and 8:1:1, Eucalyptus bark, coir or coxim, in the proportion 2:7:1, are the alternative substrates that could effectively the mixtures that contains "xaxim", in the proportions 2:7:1, 5:4:1 and 8:1:1. 


\section{INTRODUÇÃO}

No Brasil, as bromélias crescem em profusão, especialmente na Mata Atlântica. Seu cultivo ganhou impulso nos últimos tempos entre os produtores rurais, sendo hoje uma atividade economicamente rentável e uma boa opção no campo da floricultura.

O mercado brasileiro de flores e plantas ornamentais movimenta anualmente cerca de um bilhão de reais. O Estado de São Paulo é responsável por $70 \%$ deste mercado, tendo expectativa de crescimento anual de 20\% (ARRUDA et al., 1996).

Os produtores de bromeliáceas ornamentais tem possibilidade de conquistar uma parcela expressiva deste mercado, pois muitas espécies, que compõem esta família botânica, apresentam características desejáveis de uma planta omamental, como o colorido intenso e a durabilidade das brácteas de suas inflorescências, além da exuberância de suas folhas em roseta, que muitas vezes trazem a lâmina foliar variegada ou com interessantes desenhos.

Com relação ao mercado internacional, MATSUNAGA (1995) ressaltou que o Brasil tem potencial para ampliar as exportações com a produção de plantas tropicais como helicônia, antúrio, orquídea e bromélia.

Devemos considerar ainda que o cultivo em grande escala pelos horticultores pode trazer benefícios, como a redução do extrativismo predatório de nossas bromélias nativas, permitindo a conservação destas no seu ambiente natural.

A cultura de bromélias para fins comerciais é recente em nosso meio agrícola, carecendo de informações técnicas que possam promover o incremento da produtividade e da qualidade. Dentre as dificuldades que os produtores tem se defrontado com freqüência, a utilização de substrato adequado tem sido um das preocupações constantes 
no seu cultivo. Deve-se ainda ressaltar, que o xaxim, Dicksonia sellowiana, um dos componentes utilizados com frequência na formulação de substratos para o cultivo de muitas plantas ornamentais envasadas, é considerado, atualmente, como uma espécie em perigo de extinção.

Considerando-se os fatores acima mencionados, o presente trabalho teve como objetivo encontrar substratos alternativos para o cultivo de Aechmea fasciata que poderiam substituir com eficiência os substratos formulados com xaxim. Para tanto, foram testados substratos contendo nas suas formulações resíduos da indústria madeireira, subprodutos da industrialização do coco, turfa, perlita e xaxim, misturados em diferentes proporções. 


\section{REVISÃO DE LITERATURA}

\subsection{Aechmea fasciata}

Aechmea fasciata (Lindley) Baker é uma espécie da família Bromeliaceae de origem brasileira (SMITH, 1955). Conforme LEME (1994), a espécie é integrante do subgênero Platyaechmea, classificada pela primeira vez em 1828 como Bilbergia fasciata Lindley e seu nome atual, com inclusão no gênero correto, foi publicado em 1870 por J.G. Baker.

Pertencente à subfamília Bromelioideae, a $A$. fasciata apresenta quatro variedades naturais (REITZ, 1983):

a) A. fasciata var. fasciata, com folhas verdes igualmente coloridas (concolores) com faixas brancas transversais;

b) A. fasciata var. pruinosa com folhas branco-farinosas;

c) A. fasciata var. purpurea com folhas vermelho-purpúreas e

d) A. fasciata var. flavi-vittata cujas folhas têm listas longitudinais alternantes verdes e amarelas.

A. fasciata foi a primeira bromélia a ser introduzida para cultivo nos países europeus, no ano de 1836, e continua sendo uma das bromeliáceas mais cultivadas, de acordo com as observações de SAMYN \& THOMAS (1994). LEME (1994) ressaltou que a espécie, assim que foi introduzida, espalhou-se por todos os continentes, tornandose popular devido ao seu porte elegante, à folhagem atraente e à sua belíssima inflorescência e REITZ (1983) reforçando o valor omamental, salientou o fato desta 
espécie ser uma das mais utilizadas em decorações de vitrines de lojas comerciais èürōpéiās̄.

A família Bromeliaceae apresenta aproximadamente 2.500 espécies, cuja ocorrência limita-se ao continente americano, estendendo-se desde o paralelo $38^{\circ} \mathrm{N}$, nos Estados de Virgina e Texas nos EUA, norte do México e Baixa California, até $44^{\circ} \mathrm{S}$, no

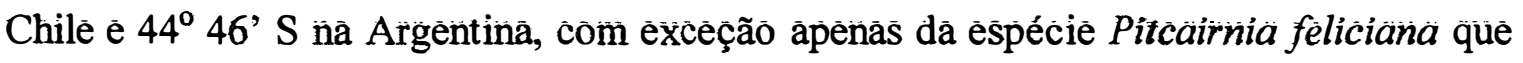
é originária da África (REITZ,1983). Embora apresente um grande número de espécies com potencial ornamental, são aproveitadas economicamente pelos horticultores apenas as espécies Guzmania minor, G. ligulata e seus híbridos, Neoregelia carolinae, Tillandsia lindenii, Vriesea splendens e algumas Vriesea hibridas, destacando-se a $A$. fasciata, conforme ZIMMER (1985). Atualmente, em São Paulo, A. fasciata é a bromélia mais comercializada, seguidas por Guzmania (var. compacta, empire, magenta, cherry e denise), $V$. sp. var. charlote, $V$. splendens e $N$. carolinae como plantas de vaso para ambientes de interiores, e Alcantarea imperialis como espécie própria para utilização em paisagismo. As bromélias mais utilizadas pelos paisagistas, segundo VITARI (1994), são $V$. regina, $A$. blanchetiana, $N$. compacta è $V$. imperialis.

A. fasciata é uma planta epífita e, como todas as bromeliáceas com o mesmo hábito, era considerada espécie em que as raízes serviam apenas como elemento de fixação, sendo que a nutrição era feita por pelos escamosos das folhas (REITZ, 1983). Porém, Sieber (1955) citado por KÄMPF (1994) avaliou os efeitos da adubação mineral feita nàs raizes e folhas, sugerindo a aplicação em ambas as partes. Em continuidade ao raciocínio de Sieber, KÄMPF (1994) conduziu um experimento no qual mostrou que, apesar de ser epífita, $A$. fasciata apresenta raízes capazes de funcionar como órgão de absorção de nutrientes, e que a adubação radicular deve ser somada à nutrição foliar, contribuindo de forma significativa para otimizar seu cultivo comercial.

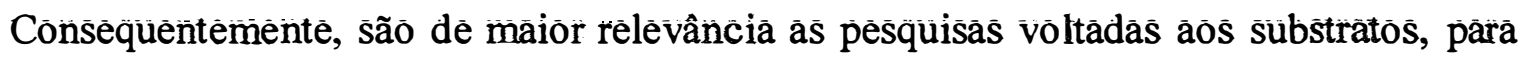
melhor aproveitamento do sistema radicular como órgão de nutrição, além da absorção foliar, principalmente através dos tricomas. Dando-se condições às raizes, através de um substrato adequado, o sistema radicular se desenvolverá a contento, ocupando todo o espaço disponível no vaso. 


\subsection{Substrato}

\subsubsection{Considerações gerais}

O substrato, na horticultura, é definido como um meio físico natural ou sintético, onde se desenvolvem as raizes das plantas que crescem em recipiente (vasos, sacos plásticos, entre outros), com um volume limitado (BALLESTER-OLMOS, 1992; PAGES-PALLARES \& MATALLANA-GONZALEZ, 1984).

O primeiro substrato para semeadura e cultivo em vaso foi desenvolvido por Lawrence e Newell em 1934, conhecido como composto "John Innes", baseado em argila, turfa e pedrisco (SHEARD, 1975; BUNT, 1976). Devido à dificuldade de se conseguir argila, Baker em 1957 conseguiu desenvolver o composto "U.C.(University of California)", sem conter argila, baseado em turfa e areia. Substratos semelhantes foram desenvolvidas por Frühstorfer e Penningsfeld na Alemanha, por Puustjarvi na Finlândia, por Bunt na Inglaterra, por Woods na Irlanda e por Sheldrake e Boodley no Estado de Nova York, EUA, segundo as observações de SHEARD (1975).

Com relação às matérias-primas empregadas, SHEARD (1975) considerou que a turfa é o componente mais usado em qualquer substrato, perfazendo de 50 a $100 \%$ do volume, sendo que a maioria tem de 75 a 100\%. O segundo maior componente é a areia, vermiculita ou perlita.

No cultivo de plantas em vasos, SHEARD (1975), preconizou que o substrato deve apresentar características como um meio saudável para o crescimento das raízes e deve, ao final do desenvolvimento destas, ser bem arejado e estar livre de pragas e doenças; fornecer todos os nutrientes, possuir alta capacidade de campo, boa disponibilidade de água e ter estabilidade física, enquanto que MINAMI (1995) ressaltou como as principais funções do substrato o fornecimento de água às plantas, suprimento de nutrientes, troca gasosa para e das raízes e suporte para as plantas.

BUNT (1976) cita que muitos materiais podem ser utilizados, separadamente ou em várias combinações, para fazer compostos sem solo. Conforme considerações de MINAMI (1986), um substrato para plantas superiores, principalmente para enchimento 
de vasilhames, deve apresentar diversas características que se obtém reunindo dois ou mais materiais para se fazer um meio único, denominado mistura. BALLESTEROLMOS (1992), discorrendo sobre o mesmo tema, considerou que a matéria orgânica, em função de sua própria natureza e espécie a ser cultivada, não era sempre adequada como único componente dos substratos. É conveniente a sua mistura com matériasprimas minerais de origem natural ou artificial como areia, perlita, vermiculita, poliestireno expandido, entre outros.

\subsubsection{Características físicas}

BOERTJE (1983), pesquisando sobre as qualidades físicas dos substratos, afirmou que estes devem apresentar, no mínimo, 20\% de volume de ar, a uma sucção mátrica de $31,6 \mathrm{~cm}$ de coluna de água $(\mathrm{pF}=1,5)$, e uma taxa de contração menor que $30 \%$ em volume, após a secagem. O autor considerou que, para as bromeliáceas, o substrato ideal deve apresentar características físicas com volume de ar maior que $25 \%$ e volume de contração após a secagem menor que $20 \%$. Ao analisar diversos substratos, concluiu que as misturas formuladas a partir de turfa com textura grosseira e de boa qualidade tinham boas possibilidades de uso no cultivo das bromeliáceas, pois determinou que o volume do ar foi alto $(33,2 \%)$ e a porcentagem de contração muito baixa $(5,6 \%)$.

BALLESTER-OLMOS (1992) considerou o valor da porosidade livre ideal entre 10 e $30 \%$, para as espécies de hábito terrestre, e de 20 a 30\%, para as espécies epifitas (bromélia) na confecção dos substratos. Observou, também, que o crescimento do sistema radicular das plantas cultivadas em vaso dava lugar a uma compactação do substrato e, consequentemente, diminuição da porosidade, prejudicando o normal desenvolvimento das plantas.

BELLÉ (1995) observou que os substratos com baixa densidade prejudicam a estabilidade das plantas, podendo tombar os vasos, enquanto que os de alta densidade reduzem o crescimento do sistema radicular, pois ocorre uma diminuição da porosidade. 
Para a redução da densidade e aumento da aeração dos substratos para as bromeliáceas, recomendou a utilização de flocos de poliuretano (isopor).

\subsubsection{Características químicas}

As plantas epífitas caracterizam por se desenvolverem em $\mathrm{pH}$ baixo e para as bromeliáceas, BALLESTER-OLMOS (1992) recomendou como $\mathrm{pH}$ adequado os valores entre 4,0 a 5,5 .

Com relação à adubação, BALLESTER-OLMOS (1992) ressaltou que a maioria dos substratos para cultivo em vasos, como a turfa e a serrapilheira, possue pequena quantidade de nutrientes disponíveis, necessitando de uma adubação básica no preparo do substrato, além da adubação de manutenção. Elaborou uma tabela de exigência nutritiva e sensibilidade à salinidade de plantas omamentais, na qual considerava $A$. fasciata como de média exigência nutritiva e sensibilidade salina, necessitando $1,5 \mathrm{~kg}$ de adubação básica por $\mathrm{m}^{3}$ de turfa e de 1 a $4 \mathrm{~g}$ de adubação de manutenção por litro de água, enquanto que a espécie Vriesea splendens (Bromeliaceae) apresentava baixa exigência nutricional e elevada sensibilidade salina, necessitando $0,5 \mathrm{~kg}$ de adubação básica por $\mathrm{m}^{3}$ de turfa e de 0,5 a $2 \mathrm{~g}$ de adubação de manutenção por litro de água.

BUNT (1976) citou Penningsfeld do Instituto de Ciência do Solo e Nutrição de Plantas que recomendava para todos os compostos adição de 2 a $5 \mathrm{~kg} / \mathrm{m}^{3}$ de turfa, cuja quantidade dependia da textura da turfa e do $\mathrm{pH}$ desejado. Fertilizante com formulação 12-12-16 e $2 \%$ de $\mathrm{Mg}$ foi adicionada na quantidade de 1 a $5 \mathrm{~kg}$ de fertilizante $/ \mathrm{m}^{3}$, proporcionando $180 \mathrm{mg} / \mathrm{l}$ de $\mathrm{N}, 80 \mathrm{mg} / \mathrm{l}$ de $\mathrm{P}$ e $200 \mathrm{mg} / \mathrm{l}$ de $\mathrm{K}$.

GALLANGHER (1975), também, citou Penningsfeld, que apresentou a classificação de muitas plantas ornamentais de acordo com a absorção de nutrientes e suscetibilidade à salinidade causada por fertilizantes em substratos, classificando-os em grupo I: plantas sensíveis à salinidade; grupo $\Pi$ : plantas moderadamente sensíveis à salinidade e grupo III: plantas tolerantes à salinidade. Entre as plantas do grupo II foram consideradas as bromélias $A$. fasciata cultivadas em vaso e Vriesea splendens, para as 
quais recomendou $1,5 \mathrm{Kg}$ do fertilizante por $\mathrm{m}^{3}$ de turfa, contendo $360 \mathrm{~g}$ de $\mathrm{N}, 80 \mathrm{~g}$ de $\mathrm{P}$ e $200 \mathrm{~g}$ de $\mathrm{K}$.

\subsubsection{Substratos para bromeliáceas}

FOSTER (1953) recomendou substratos formulados com 3 partes de areia grossa ou granito moído e 3 partes de turfa, fibra de osmunda ou serragem para as bromeliáceas dos gêneros Billbergia, Aechmea, Neoregelia, Nidularium e Cryptanthus.

BUNT (1976) tratou da formulação e preparo de compostos para vasos, citando a mistura denominada "Cornell Epiphyte Mix", usada para plantas que requerem boa drenagem e aeração, como as bromélias epífitas. A mistura era composta de 1/3 de turfa de esfagno (peneira de malha $0,8 \mathrm{~cm}$ ), de $1 / 3$ de "Douglas red" ou casca de abeto branco (0,3-0,6 cm) e de $1 / 3$ de perlita (tamanho médio).

WALL (1988) recomendou, para a maioria das bromélias, o substrato contendo areia grossa, turfa de esfagno e terra vegetal em volumes iguais. O substrato assim preparado proporcionou a drenagem necessária às espécies da família Bromeliaceae.

Para as bromélias epifitas, WILLIAMS \& HODGSON (1990) recomendaram a mistura com volumes iguais de turfa de esfagno, areia grossa e pedriscos horticulturais. Para melhorar a drenagem, misturaram uma porção de casca de pinheiro em forma de "chips". Os autores não especificaram a quantidade da casca de pinheiro. No caso das bromélias terrestres ou rupícolas, os autores recomendaram a mistura $n^{0} .1$ de John Innes ou composto para semeadura e estaquia, com uma porção de pedrisco horticultural ou perlita. A proporção desses componentes, também, não foram especificados.

Um dos componentes utilizados para a confecção de substratos foi a serapilheira compostas por acículas de pinheiro que apresentou leveza e boa porosidade $(60 \%$ de porosidade livre). Misturada com turfa foi recomendada para as bromeliáceas e Anthurium, apresentando $\mathrm{pH}$ entre 5,8 a 6,3 e baixo teor de nutrientes, por BALLESTER-OLMOS (1992).

KAMPF (1992a) considerou que o cultivo das bromélias (epifitas) exigiam substratos de baixa densidade, alta permeabilidade e aeração. A presença de elevada 
fração de matéria orgânica no meio de cultivo pode melhorar tais características. Misturas com solo mineral poderiam ser usadas para o cultivo em recipientes, desde que sejam adicionados condicionadores para diminuir o peso e/ou aumentar a porosidade do meio.

DIMMITT (1995) ressaltou que os substratos, também para as bromélias, deveriam ser ácidos, com alta capacidade de campo, boa drenagem e aeração. Citou a utilização do substrato de Cymbidium que é composto de "casca" de Cymbidium, perlita grossa e húmus na proporção de 1:1:1. Outros componentes usuais citados pelo autor foram as pedra-pomes, rocha vulcânica, carvão, turfa fibrosa, esfagno e fibras de samambaia arborescente.

Em busca de substratos alternativos para substituir o xaxim no cultivo de $A$. fasciata, D'ANDRÉA (1997) comparou misturas compostas de xaxim, casca de coco e Pinus, bagaço de cana-de-açucar, cacos de cerâmica, vermiculita e húmus. Concluiu, após 540 dias de cultivo, que o substrato contendo $45 \%$ de xaxim, $45 \%$ de casca de Pinus e $10 \%$ de húmus e o substrato constituído de $45 \%$ de xaxim, $45 \%$ de casca de coco e $10 \%$ de húmus foram os mais eficientes. Entre os substratos que não continham xaxim em sua composição, destacou-se o substrato contendo $45 \%$ de casca de coco, $45 \%$ de casca de Pinus e $10 \%$ de húmus.

\subsubsection{Componentes}

\subsubsection{Xaxim}

LORENZI \& SOUZA (1995) descreveram Dicksonia sellowiana (Presl.) Hook como uma Pteridophyta da família Dicksoniaceae, conhecida popularmente como xaxim, samambaiaçu, samambaiaçu-imperial ou feto arborescente, crescendo como um arbusto semi-lenhoso de tronco ereto, fibroso, espesso, nativa do Brasil, com 2 a $4 \mathrm{~m}$ de altura, de folhagem omamental e de crescimento muito lento. Destacaram que o tronco dá origem aos vasos de xaxim e em pedaços ou fibra proporcionam o substrato para cultivo de orquídeas e de muitas outras plantas. GONÇALVES (1992) descreveu o 
xaxim como a fibra esponjosa que envolve o tronco da samambaia arbórea e afirmou que a fibra cresce nos exemplares que atingiram um certo tamanho e estes são colhidos e moídos em fragmentos que permitiriam ser manipulados para o enchimento de vasos. Segundo SANTOS (1992), o xaxim é uma planta incluída na categoria "em perigo de extinção" e sua sobrevivência será improvável se os fatores causais não forem sustados. Faz parte da lista oficial de espécies da flora brasileira ameaçada de extinção, regulamentada através da portaria no 06-N de 15 de janeiro de 1992 no Diário Oficial União de 06 abril de 1992 (BRASIL, 1992). SILVA (1997) ressaltou que, apesar da existência de instrumentos legais que restringiriam a comercialização do xaxim e estabeleceram mecanismos de proteção para a espécie, o comércio e a degradação nas áreas de ocorrência ainda constituem práticas comuns no país. KÄMPF (1992b), citando Backes, descreveu algumas propriedades do pó-de-xaxim, como a alta capacidade de troca catiônica, baixa densidade, alta capacidade de retenção de água, alta capacidade de aeração e média estabilidade do volume. DEMATTÊ (1992), examinando este material, observou $\mathrm{pH}$ de 3,20, quando novo, e de 4,85, após 3 anos de utilização. A densidade encontrada foi de $63,74 \mathrm{~g} /$ litro e na determinação de nutrientes, encontrou elementos químicos nas concentrações de $0,81 \%$ de $\mathrm{N}, 0,11 \%$ de $\mathrm{P}, 1,17 \%$ de $\mathrm{K}, 0,85 \%$ de $\mathrm{Ca}$, 0,20\% de Mg, 0,16\% de S, 10 ppm de B, 46 ppm de Cu, 4.750 ppm de Fe, 137 ppm de Mn, 40 ppm de Zn e 0,01 ppm de Mo.

\subsubsection{2."Coxim"}

DEMATTÊ (1992) com o intuito de buscar alternativas para substituir o xaxim verdadeiro Dicksonia sellowiana (Presl.) Hook., no cultivo de orquídeas epífitas, testou o "coxim", fabricado a partir do resíduo do fruto de Cocus nucifera L., encontrando vantagens na facilidade de manuseio, boa aeração e drenagem, grande capacidade de retenção de umidade depois de algum tempo de uso, longa durabilidade e composição adequada de nutrientes, após a lixiviação inicial. Determinou também o pH, que variou entre 4,06, quando novo, e 4,88, após três anos de cultivo. A densidade encontrada em "coxim" novo foi de $271,33 \mathrm{~g} /$ litro, enquanto que a concentração de nutrientes foi $0,41 \%$ 
de $\mathrm{N}, 0,24 \%$ de $\mathrm{P}, 6,00 \%$ de $\mathrm{K}, 1,30 \%$ de $\mathrm{Ca}, 0,65 \%$ de $\mathrm{Mg}, 0,08 \%$ de $\mathrm{S}, 18 \mathrm{ppm}$ de $\mathrm{B}$, 13 ppm de $\mathrm{Cu}, 3.100$ ppm de Fe, 36 ppm de $\mathrm{Mn}, 58$ ppm de $\mathrm{Zn}$ e 0,53 ppm de Mo.

Embora não sejam utilizadas em forma de cubos prensados, como no coxim, as fibras curtas e pó, que sobram do processamento da fibra de coco, também, mostraramse aceitáveis como substituto da turfa de esfagno na confecção de substratos (NOGUERA, et al., 1997).

\subsubsection{Fibra de coco}

O fruto do coqueiro (Cocos nucifera L.) é uma drupa ovóide, quase globosa, com até $0,30 \mathrm{~m}$ de comprimento e $0,25 \mathrm{~m}$ de diâmetro, apresentando o mesorcarpo espesso, fibroso de cor acastanhada, quando seco, e de grande aproveitamento industrial. De cada 200 cocos descascados consegue-se $1 \mathrm{~m}^{3}$ de cascas, pesando $50 \mathrm{~kg}$ (OLIVEIRA et al., 1975).

A fibra de coco na forma de pó apresentou espaço poroso de inicial de $13,7 \%$ e após 5 meses de $11,0 \%$ e capacidade inicial de retenção de água de $35,7 \%$ e após 5 meses de 39,2\%. (MEEROW, 1994)

As fibras podem ser compostadas, secas e comprimidas em blocos para facilitar o transporte. Os blocos são reidratados e utilizados como substratos. $\mathrm{O}$ fruto do coqueiro produz fibras menores que o da turfa e quando devidamente processadas e compostadas apresentam propriedades similares às das turfas. Apresentam $\mathrm{pH}$ em torno de $7 \mathrm{e}$ aeração ligeiramente menor. A fibra de coco pode ser usada como substituta da turfa ou em combinação (FONTENO, 1996).

\subsubsection{Perlita}

HARTMANN \& KESTER (1983) definiram a perlita como um material de sílica branco-cinzento, de origem vulcânica e explorada nas minas de lava. O minério bruto é triturado, peneirado e aquecido no forno a $760{ }^{\circ} \mathrm{C}$, no qual uma pequena quantidade de umidade presente nas partículas transforma-se em vapor, expandindo-as em pequenos 
grãos esponjosos, muito leves. O processamento a alta temperatura tornava o produto estéril com partículas de 1,6 a $3 \mathrm{~mm}$ de diâmetro, muito utilizada na horticultura. Perlita retém de 3 a 4 vezes o seu peso em água. É essencialmente neutra, com pH entre 6,0 a 8,0 , não tendo capacidade de troca catiônica e não contendo nutrientes minerais. Já MACDONALD (1993) referiu-se à perlita como um material vulcânico de ocorrência natural, quimicamente composto de silicatos de alumínio, resultando em uma estrutura celular que tornava a perlita um excelente material para uso como substrato, apresentando uma boa drenagem e aeração. Segundo OLYMPIOS (1992), a perlita apresenta composição química composta de $\mathrm{SiO}_{2}$ (73,06\%), $\mathrm{Al}_{2} \mathrm{O}_{3}(15,30 \%), \mathrm{Fe}_{2} \mathrm{O}_{3}$ (1,05\%), $\mathrm{CaO}(0,80 \%), \mathrm{MgO}(0,05 \%), \mathrm{K}_{2} \mathrm{O}(4,50 \%)$ e $\mathrm{Na}_{2} \mathrm{O}(3,65 \%)$.

A necessidade de haver diferentes granulometrias de perlita é muito importante para sua utilização. O material mais fino poderia ser usado para elevar a quantidade de água facilmente disponível e com granulometria mais grosseira poderia ser utilizado para aumentar a aeração dos substratos, segundo VERDONCK (1983)

\subsubsection{Casca de árvore}

Casca de árvores são utilizadas há anos e os gêneros utilizados, na sua maioria em horticultura, são Pinus, Picca, Abies, Sequoia, Pseudotsuga, Fagus, Betula e Quercus, e a espécie Cupressus macrocarpa, segundo as observações de BALLESTÉROLMOS (1992).

Experimentos com Primula sp. e Petunia sp., conduzidos por DEULOFEU \& AGUILA-VILA (1983), mostraram que a casca de pinheiro fermentada foi adequada e capaz de substituir a turfa de esfagno.

No Brasil é abundante a casca de pinheiro como subproduto da exploração silvicultural de Pinus spp. e Eucalyptus spp. Foi considerado por BALLESTEROLMOS (1992) como um componente de grande interesse no cultivo de plantas epífitas, como no cultivo de orquídeas, na proporção de $80 \%$ de casca de pinheiro, $10 \%$ de turfa e $10 \%$ de poliestireno expandido. Para a preparação da casca de pinheiro, após a 
peneiração, é importante que se faça a compostagem durante 2 a 4 meses com adição de nitrogênio.

BELLÉ (1995) ressaltou que as cascas de árvores utilizadas nos substratos, poderiam ser compostadas durante um período de 1 a 4 meses ou usadas frescas e apresentam $\mathrm{pH}$ neutro, elevada porosidade total, baixa salinidade e baixa densidade.

\subsection{Casca de Eucalyptus}

DEMATTÊ (1992), realizando pesquisas com casca de Eucalyptus grandis Hill ex Maiden (pura) no cultivo de orquídeas e pífitas ao longo de três anos, determinou que o pH variou de 3,99, quando nova, até 4,72, após três anos de cultivo. A casca apresentou uma densidade de 96,72 g/litro e foram encontradas as seguintes concentrações de nutrientes em material novo: $0,32 \%$ de $N, 0,07 \%$ de $\mathrm{P}, 0,20 \%$ de $\mathrm{K}$, 1,32\% de $\mathrm{Ca}, 0,40 \%$ de $\mathrm{Mg}$, 0,01\% de S, 13 ppm de B, 17 ppm de $\mathrm{Cu}, 793$ ppm de $\mathrm{Fe}$, $1.291 \mathrm{ppm}$ de $\mathrm{Mn}, 18 \mathrm{ppm}$ de $\mathrm{Zn}$ e 0,01 ppm de Mo.

A utilização isolada da casca de $E$. grandis não se mostrou viável, principalmente pelas alterações estruturais que prejudicaram a porosidade no cultivo de orquídeas epífitas.

\subsection{Casca de Pinus}

Segundo MACDONALD (1993), as cascas de Pinus são classificadas no grupo de madeiras facilmente decomponíveis e devem sofrer compostagem de no mínimo 6 semanas, tornando-se mais escuras, com aumento na capacidade de retenção de água, facilitando a remoção de substâncias nocivas e abaixando o nível de $\mathrm{Mn}$ tóxico, bem como aumentando o pH, se não devidamente controlada. GONÇALVES (1992) considerou a casca de Pinus como material curado e moído, apresentando-se na forma de fragmentos de tamanhos variáveis, desde $1 \mathrm{~cm}$ até pó, composta de celulose e outros carbohidratos similares. Por ser uma matéria orgânica, a decomposição vai ocorrendo à medida em que é utilizada. Quanto à composição química do Pinus elliottii Englm., o 
mesmo autor citou as seguintes concentrações de nutrientes: $0,28 \%$ de $\mathrm{N}, 0,02 \%$ de $\mathrm{P}$, $0,10 \%$ de $\mathrm{K}, 0,51 \%$ de $\mathrm{Ca}, 0,14 \%$ de $\mathrm{Mg}, 9$ ppm de $\mathrm{B}, 77 \mathrm{ppm}$ de $\mathrm{Cu}, 790$ ppm de $\mathrm{Fe}$, 119 ppm de Mn e 114 ppm de Zn. Com relação ao pH, DIRR \& HEUSER JR. (1987) citaram o valor de 4,90, encontrado em casca de Pinus moído.

WHITCOMB (1984), referindo-se à casca de Pinus, descreveu a importância do tamanho das partículas que, quanto menores, maior é a redução da aeração do substrato, aumentando a capacidade de retenção de água. Além disso, partículas menores decompõem-se com maior intensidade do que aquelas de maior tamanho. Partículas iguais ou menores que $0,3 \mathrm{~cm}$ poderiam se decompor muito rapidamente para serem utilizadas em culturas de ciclo longo (um ou mais ciclos de crescimento), enquanto que são aceitáveis em produções de ciclo curto. Em geral, as cascas de Pinus são processadas em moinhos de martelo e peneiradas a tamanhos entre 2 e $2,5 \mathrm{~cm}$.

$\mathrm{Na}$ determinação do número de vezes que a casca de pinheiro curada pode ser usada, VERDONCK (1980) verificou que casca de pinheiro fresco permite três períodos de crescimento, enquanto utilizando casca de pinheiro seco em plantas omamentais sensíveis, como Cordiline terminalis, suas propriedades físicas foram afetadas no terceiro período de crescimento.

\subsubsection{Turfa}

GALLANGHER (1975) afirmou que a turfa é altamente ácida, variando o $\mathrm{pH}$ de 3,7 a 4,2, portanto, impróprio para a maioria das plantas. Algumas ericáceas como a azaléia podem crescer apenas com a adição de fertilizantes, mas a maioria de outras plantas necessitam de calagem.

Segundo KAVANAGH \& HERLIHY (1975), turfa é um acúmulo de matéria orgânica não decomposta totalmente, originada principalmente de vegetais, sendo que a parcial decomposição se deve às condições de um ambiente anaeróbico desfavorável à intensa atividade microbiológica que favoreceram a formação de turfa. Ressaltaram, também, que os principais fatores que determinaram o local e o tipo de formação da turfa, foram o clima, topografia, e a natureza química da água e solo. BUNT (1976) 
definiu turfa como um material utilizado para fazer substratos sem solo, utilizada separadamente ou em várias combinações, formada a partir da decomposição parcial de plantas que cresceram em locais chuvosos, de alta umidade e baixas temperaturas no verão.

Com relação às propriedades fisicas e químicas da turfa, KÄMPF (1992b), relacionou algumas características como a alta porcentagem de matéria orgânica, alta capacidade de troca catiônica, baixa densidade, alta capacidade de retenção de água, média a alta capacidade de aeração, muito pouco nutrientes, média estabilidade do volume, alto poder tampão e baixa capacidade de suporte. 


\section{MATERIAL E MÉTODOS}

\subsection{Instalação do experimento}

\subsubsection{Local}

O experimento foi desenvolvido em estufa na área experimental do Departamento de Produção Vegetal da Escola Superior de Agricultura "Luiz de Queiroz" da Universidade de São Paulo, em Piracicaba, SP.

A estufa tinha $5 \mathrm{~m}$ de largura e $22 \mathrm{~m}$ de comprimento como medidas internas, 2 $\mathrm{m}$ de pé direito e altura do vão central de 4,0 m. Foi classificada como modelo arco com pé direito. A orientação da construção foi no sentido norte-sul, segundo o seu comprimento.

A cobertura da estufa e seu fechamento lateral até a altura de $0,6 \mathrm{~m}$ foram feitos com filme de polietileno aditivado, transparente, e de 70 micras de espessura. A porção lateral superior a $0,6 \mathrm{~m}$ e as partes frontais foram fechadas com tela de sombreamento a $50 \%$.

Os vasos foram dispostos na estufa em duas bancadas de madeira e concreto, posicionadas no sentido longitudinal, com 1,60 $\mathrm{m}$ de largura, $21,00 \mathrm{~m}$ de comprimento $\mathrm{e}$ $0,70 \mathrm{~m}$ altura.

Conforme é usual entre os produtores de bromélias para fins comerciais, o sombreamento foi realizado com sombrite $70 \%$, fixado no teto da estufa a uma altura de $2,5 \mathrm{~m}$. 


\subsubsection{Mudas}

O experimento foi iniciado em 20 de julho de 1997, utilizando-se mudas de $A$. fasciata, variedade Rolf I, com idade de 81 dias, obtidas a partir de cultura de meristemas e produzidas em bandejas de poliestireno com 200 células, com formato de pirâmide invertida, tendo como substrato fibra de xaxim e glóbulos de isopor. Foram adquiridas do laboratório de micropropagação da empresa "Rolf Bromélias", especializada na produção de bromélias, sediada em Campinas, SP. Passados 5 dias do transplante, as plantas apresentavam, em média, 6,53 folhas, altura de 3,72 cm, maior diâmetro da roseta de $11,46 \mathrm{~cm}$ e terceira folha com $1,32 \mathrm{~cm}$ de largura.

\subsubsection{Recipientes para cultivo}

\subsubsection{Cultivo em vaso número 10}

$\mathrm{Na}$ primeira etapa, durante 5 meses, as plantas foram cultivadas em vasos plásticos, tamanho número 10 , de cor preta, com diâmetro de $10 \mathrm{~cm}$ na parte superior, $7,7 \mathrm{~cm}$ na parte inferior e $7,5 \mathrm{~cm}$ de altura, providos de 4 orificios de drenagem no fundo e capacidade de $0,45 \mathrm{~L}$. Os vasos foram preenchidos no seu fundo com pedras britadas para facilitar a drenagem.

\subsubsection{Cultivo em vaso número 15}

Após 5 meses do início do experimento, as plantas foram transferidas em caráter definitivo para vasos plásticos, tamanho número 15 , de cor preta, com $15 \mathrm{~cm}$ de diâmetro na parte superior, $10,5 \mathrm{~cm}$ na parte inferior e $12,5 \mathrm{~cm}$ de altura, 8 orifícios de drenagem no fundo e capacidade de 1,25 L. Estes vasos, também, continham pedras britadas para facilitar a drenagem. 


\subsubsection{Componentes dos substratos}

As matérias-primas dos substratos que constituíram os tratamentos foram obtidas de várias fontes produtoras. Cascas de Pinus e de Eucalyptus foram adquiridas da "Terra do Paraíso", Município de Holambra, SP. Perlita e turfa foram fornecidas pela "Eucatex Química e Mineral Ltda.”, com sede em São Paulo, SP. Fibra de coco foi obtida da empresa "Vida Verde", localizada no município de Moji-Mirim, SP. Coxim foi cedido pela empresa Artesanato Coxim, Recife, PE. Xaxim foi obtido no Instituto de Botânica, São Paulo, SP.

As cascas de Pinus foram compostadas e selecionadas em peneira com malha de uma polegada de diâmetro, enquanto que as cascas de Eucalyptus sofreram apenas compostagem, não sendo peneiradas. A fibra de coco foi processada em moinho de martelo com peneira de uma polegada e não foram compostadas. $\mathrm{O}$ coxim era formado de cubos, denominado "cubo 2", nas dimensões de $20 \times 20 \times 10 \mathrm{~mm}$, e foi imerso durante 8 dias em água com renovação diária, para eliminação do tanino, conforme as instruções do fabricante. O xaxim era constituído de fibras obtidas a partir da moagem de pedaços de tronco de xaxim no moinho de martelo. A perlita de uso agrícola (AG-8) tinha com massa específica aparente entre 80 a $140 \mathrm{~kg} / \mathrm{m}^{3}$ e granulometria fina. A turfa era classificada como fibrosa e peneirada em malha de $40 \mathrm{~mm}$

\subsubsection{Dados meteorológicos}

Os dados de temperatura média, máxima e mínima, e umidade relativa do ar foram medidos pelo posto agrometeorológico do Departamento de Ciências Exatas da ESALQ-USP que se encontrava nas proximidades do experimento. $O$ posto estava localizado nas coordenadas $22^{\circ} 42^{\prime} 30^{\prime \prime}$ latitude sul e $47^{\circ} 38^{\prime} 30^{\prime \prime}$ longitude oeste de Greenwich, a uma altitude de $546 \mathrm{~m}$. As médias mensais são apresentadas na tabela 01 . 
Tabela 01. Médias mensais de temperatura e umidade relativa do ar observadas entre julho de 1997 a outubro de 1998, medidas pelo posto agrometeorológico do Departamento de Ciências Exatas da ESALQ-USP.

\begin{tabular}{|c|c|c|c|c|c|}
\hline \multirow[t]{2}{*}{ ano } & \multirow[t]{2}{*}{ mês } & \multirow{2}{*}{$\begin{array}{l}\text { umidade } \\
\text { relativa } \\
(\%)\end{array}$} & \multicolumn{3}{|c|}{$\begin{array}{c}\text { temperatura } \\
\left({ }^{\circ} \mathrm{C}\right)\end{array}$} \\
\hline & & & máxima & mínima & média \\
\hline \multirow{6}{*}{1997} & julho & 77,26 & 26,12 & 11,29 & 18,71 \\
\hline & agosto & 70,81 & 27,82 & 11,23 & 19,53 \\
\hline & setembro & 71,43 & 29,38 & 15,31 & 22,35 \\
\hline & outubro & 76,55 & 29,36 & 17,25 & 23,30 \\
\hline & novembro & 81,57 & 30,34 & 19,54 & 24,94 \\
\hline & dezembro & 79,74 & 31,11 & 19,68 & 25,40 \\
\hline \multirow{10}{*}{1998} & janeiro & 78,77 & 31,71 & 20,61 & 26,16 \\
\hline & fevereiro & 90,07 & 30,03 & 20,46 & 25,25 \\
\hline & março & 85,35 & 31,01 & 19,80 & 25,40 \\
\hline & abril & 81,03 & 28,39 & 17,02 & 22,71 \\
\hline & maio & 81,39 & 24,95 & 12,80 & 18,87 \\
\hline & junho & 86,60 & 24,12 & 9,86 & 17,00 \\
\hline & julho & 80,61 & 25,89 & 10,82 & 18,35 \\
\hline & agosto & 77,00 & 27,40 & 14,36 & 20,88 \\
\hline & setembro & 76,30 & 27,65 & 15,29 & 21,47 \\
\hline & outubro & 83,42 & 27,06 & 16,33 & 21,70 \\
\hline
\end{tabular}

\subsection{Condução do experimento}

\subsubsection{Espaçamento}

As plantas foram dispostos em espaçamentos diferentes durante o cultivo, conforme o crescimento, para minimizar os efeitos da competição entre as plantas. Inicialmente adotou-se o espaçamento de $0,12 \times 0,12 \mathrm{~m}$, até atingir as medidas definitivas de $0,4 \mathrm{~m}$ entre linhas e $0,35 \mathrm{~m}$ entre as plantas. 


\subsubsection{Adubação}

Foram feitas adubações foliares e no substrato (radicular), na dose e freqüência semanal recomendada por KÄMPF (1994), modificando-se a fórmula do fertilizante e forma de aplicação.

A solução preparada foi aplicada com pulverizador costal, marca Jacto, com capacidade de $5 \mathrm{~L}$, utilizando-se o adubo foliar de fórmula 7:17:35, marca "Hydro Albatroz", fabricado por Hydro Agri, contendo ainda os micronutrientes $\mathrm{Mg}(3 \%), \mathrm{B}$ (0,02\%), Ca (0,10\%), Cu (0,02\%), Fe (0,15\%), Mn (0,10\%), Mo (0,005\%) e Zn (0,02\%) na dose de $0,1 \%$, gastando-se na fase final do experimento 20 litros da solução na área ocupada pelas plantas. Não se aplicou nenhuma solução com nutrientes na cisterna das bromélias.

As adubações no substrato foram realizadas na forma de fertirrigação, através da aplicação manual do fertilizante solúvel em água de fórmula 15:5:30, marca Krystalon, fabricado pela Hydro Fertilizantes, na dose de 0,2\%. Continha ainda $\mathrm{Mg}(3 \%), \mathrm{S}(2 \%)$, B (0,025\%), Mo (0,004\%), Cu (0,01\%), Fe (0,07\%), Mn (0,04\%) e Zn (0,025\%). Aplicou-se $50 \mathrm{ml}$ da solução por planta durante o cultivo no vaso número 10 e $170 \mathrm{ml}$ por planta durante o cultivo no vaso número 15 .

\subsubsection{Irrigação}

A irrigação instalada na estufa foi microaspersão, utilizando-se microaspersores com pêndulo e bailarina, dotados de válvula anti-gotejo, com baixa vazão. As linhas de distribuição foram fixadas na estrutura da estufa de forma a ficarem suspensas. A irrigação foi realizada 2 vezes por semana, uma na adubação e a outra por microaspersão. Durante o inverno (menor evapotranspiração), a freqüência de irrigação passou a ser semanal juntamente com a adubação. 


\subsubsection{Controle de pragas e doenças}

Durante o cultivo foram realizadas quatro pulverizações com o inseticida clorpirifós a $0,1 \%$ para o controle de lagartas que foram encontradas alimentando-se das folhas em duas ocasiões. Foi constatada, também, presença de bacteriose em algumas plantas, prejudicando as folhas mais novas e causando a morte de apenas uma planta. Como medida de controle, a partir de sua constatação, pulverizou-se quinzenalmente, cálcio quelatizado a 0,3\%, marca Basfoliar cálcio da Basf.

Preventivamente, para o controle da fusariose, causado pelo fungo Fusarium oxysporum, pulverizou-se, mensalmente, benomil a $0,07 \%$ e, a cada 2 meses, tratou-se os substratos com uma solução do mesmo fungicida a $0,1 \%$.

\subsubsection{Indução floral}

As bromélias foram induzidas ao florescimento com etefon, (ácido 2-cloroetil fosfônico), $240 \mathrm{~g} . \mathrm{L}^{-1}$, pertencente ao grupo químico ácido fosfônico, na concentração de 800 ppm do princípio ativo, conforme a dose recomendada por MELE-GRAU \& MESSEGUER-PEYPOCH (1980). Para garantir a total indução floral e a uniformidade na emergência da inflorescência, modificou-se a quantidade da solução por planta e a técnica de aplicação recomendada pelos autores acima mencionados. Para tanto, a água contida nas cisternas das rosetas foi eliminada, emborcando-se as plantas e drenando-se todo o líquido existente. Logo a seguir, aplicou-se manualmente, no centro da roseta, $135 \mathrm{ml}$ da solução indutora. 


\subsection{Avaliações}

\subsubsection{Medidas da parte vegetativa}

\subsubsection{Número de folhas}

O número de folhas foi avaliado pela contagem das folhas de cada planta, considerando-se as folhas mais desenvolvidas e aquelas mais novas em crescimento na parte central da roseta. Não foram consideradas as folhas baixeiras, isto é, as folhas consideradas em processo de senescência.

\subsubsection{Altura da planta}

A altura da planta foi mensurada com régua graduada em centímetros, considerando-se a medida compreendida entre a superfície do substrato, correspondente ao nível do colo, e à extremidade superior formada pela folha mais alta.

\subsubsection{Maior diâmetro da planta}

O maior diâmetro da planta foi determinado utilizando-se paquímetro, marca Mitutoyo ou régua com escala em centímetros, conforme o tamanho da planta, considerando-se as extremidades de duas folhas opostas que apresentavam a maior dimensão, conforme esquematizado na figura 01 .

\subsubsection{Diâmetro médio da planta}

O diâmetro médio da planta foi determinado calculando-se a média aritmética de dois eixos ortogonais, formados pelo maior diâmetro da planta e do eixo a $90^{\circ} \mathrm{em}$ relação ao maior diâmetro. 


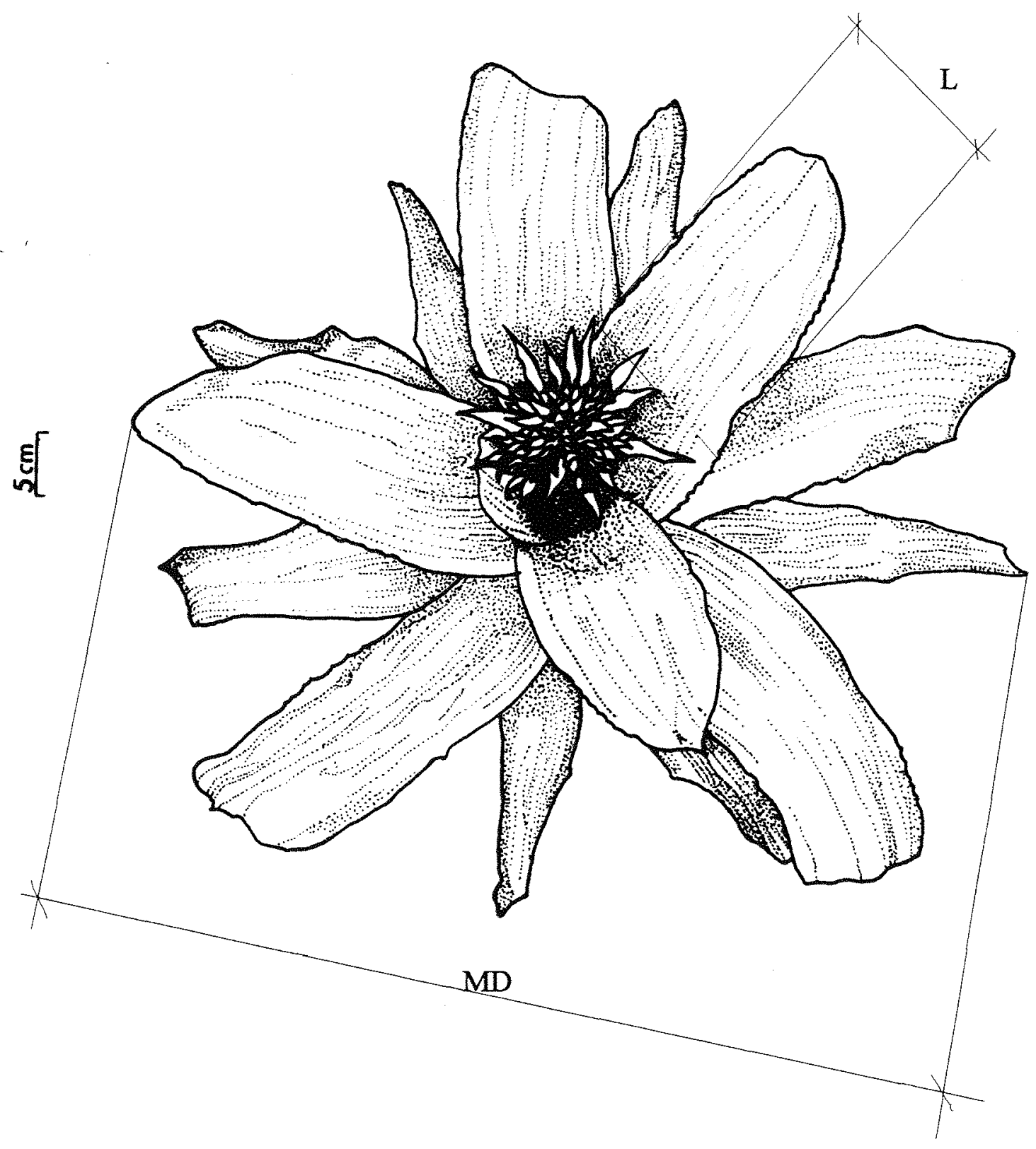

Figura 01. Desenho esquemático mostrando o critério adotado para a medida do maior diâmetro (MD) e folha com maior largura (L) da espécie $A$. fasciata Lindley (Baker), ESALQ-USP, Piracicaba, SP. 


\subsubsection{Largu ra da terceira folha}

Para a dimensão considerada tomou-se a terceira folha contada a partir do centro da roseta, conforme a metodologia adotada por MELE-GRAU \& MESSEGERPEYPOCH (1980). Mediu-se com paquímetro, marca Mitutoyo, a maior largura da folha.

\subsubsection{Folha com maior largura}

Medida tomada na folha com maior largura, conforme a ilustração mostrada na figura 01, utilizando-se paquímetro, marca Mitutoyo.

\subsubsection{Diâmetro do colo da planta}

Medida tomada no colo da planta, no nível do substrato, utilizando-se paquímetro, marca Mitutoyo.

\subsubsection{Medidas da inflorescência}

\subsubsection{Comprimento da inflorescência}

A dimensão considerada foi mensurada no sentido do maior comprimento da base ao ápice da inflorescência, conforme a figura 02 , e utilizando-se paquímetro, marca Mitutoyo.

\subsubsection{Maior diâmetro da inflorescência}

O diâmetro da inflorescência foi medida, tomando-se a maior dimensão formada entre as brácteas basais opostas da inflorescência, conforme podemos notar na figura 02 . $\mathrm{O}$ instrumento utilizado foi o paquímetro, marca Mitutoyo. 


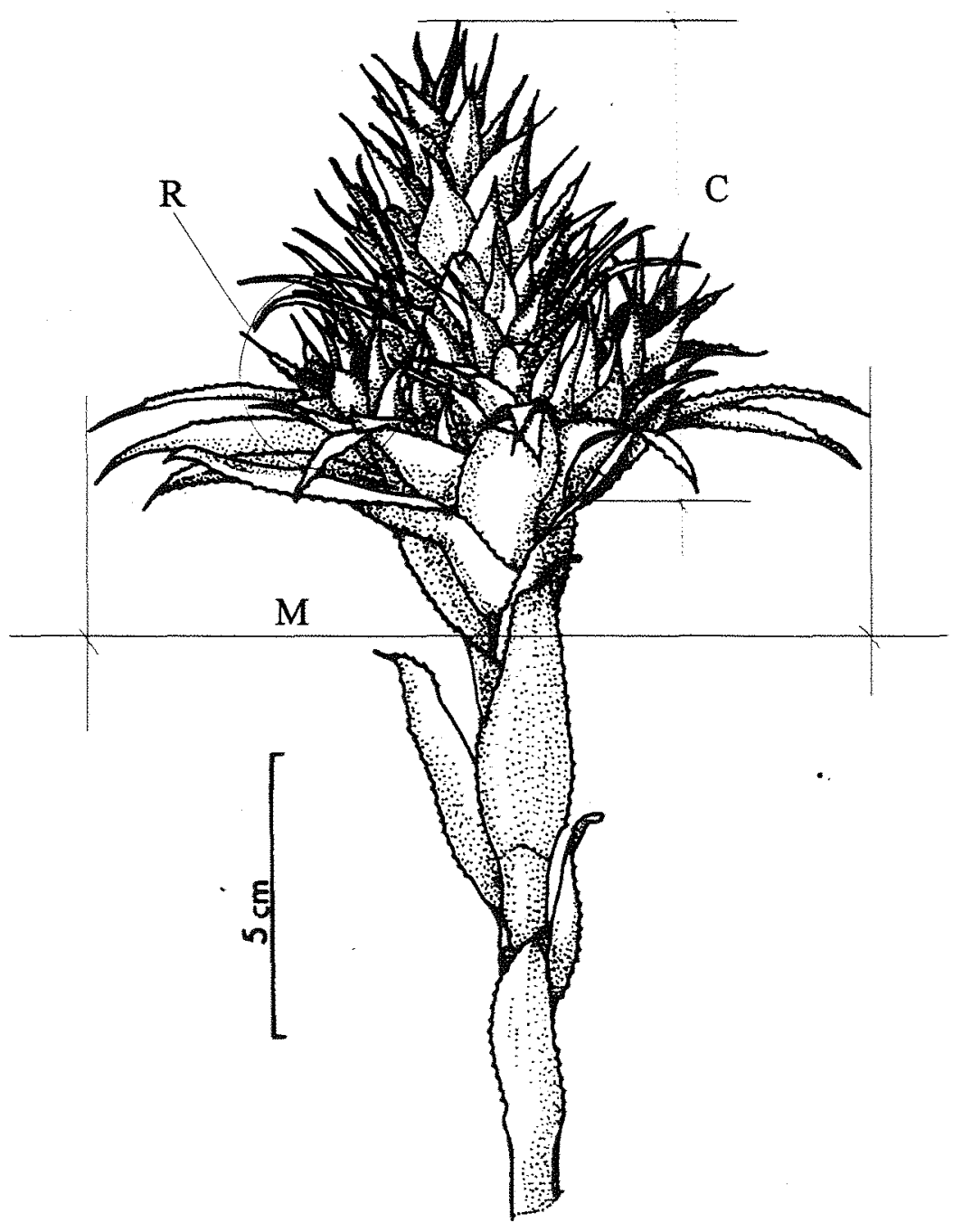

Figura 02. Desenho esquemático mostrando o critério adotado para a medida do maior diâmetro $(M)$ e do comprimento da inflorescência $(C)$ e destaque de um ramo da inflorescência $(\mathrm{R})$ da espécie $A$. fasciata Lindley (Baker), ESALQ-USP, Piracicaba, SP. 


\subsection{3. Área foliar e massa seca}

\subsubsection{1. Área foliar}

As folhas destacadas manualmente foram levadas ao laboratório, onde foi determinada a área foliar de cada planta, através da integração da superfície do limbo foliar individualmente e totalizado automaticamente pelo medidor de área. Para tanto, utilizou-se do medidor de área marca LI-COR, modelo LI-3100. Foram consideradas todas as folhas de três plantas escolhidas ao acaso.

\subsubsection{Massa seca das folhas}

As folhas foram destacadas do caule através de arranquio manual, separando-as do caule ao longo do pecíolo e acondicionadas em sacos de papel kraft para secagem em estufas, marca Marconi, modelo MA 037, dotadas de sistema para circulação e renovação de ar a uma temperatura de $70^{\circ} \mathrm{C}$, até atingir peso constante. Após a secagem completa, o material foi pesado em balança analítica, marca Marte, modelo AS 2000, com precisão de centésimo de grama, logo após a retirada da estufa para evitar a hidratação da amostra.

\subsubsection{Massa seca da inflorescência}

As inflorescências foram destacadas do escapo floral, utilizando-se tesoura de poda, cortando-as rente à base da inflorescência e acondicionadas em sacos de papel kraft. Determinou-se a massa seca seguindo-se a metodologia descrita no item 3.3.3.2. 


\subsubsection{Massa seca do escapo floral}

O escapo floral foi retirado do caule na junção que determina a separação entre as duas peças e a base da inflorescência, que pode ser observado na figura 03. Determinou-se a massa seca seguindo-se a metodologia descrita no item 3.3.3.2.

\subsubsection{Massa seca da raiz}

Para a retirada do substrato, o sistema radicular foi inicialmente imerso em água e em seguida limpo com lavadora de alta pressão, marca Kãrcher, modelo 410. Durante a operação, as raízes foram contidas por uma peneira de determinação granulométrica da marca Granutest $n^{0} \cdot 14$, para evitar perdas de raízes. Posteriormente, as raízes foram processadas manualmente, retirando-se todas as impurezas e acondicionadas em sacos de papel kraft. Determinou-se a massa seca seguindo a metodologia descrita no item 3.3.3.2.

\subsubsection{Massa seca do caule}

O caule foi isolado da planta eliminado-se as folhas e raízes manualmente, enquanto que o escapo floral foi separado com tesoura de poda e em seguida foi ensacado em sacos de papel kraft. O esquema mostrando o caule pode ser observado na figura 03. Determinou-se a massa seca seguindo a metodologia descrita no item 3.3.3.2.

\subsubsection{Massa seca total}

Massa seca da planta foi a somatória de todas as partes das plantas pesadas separadamente, ou seja, a soma das massas das folhas, caule, raiz, escapo floral e inflorescência. 


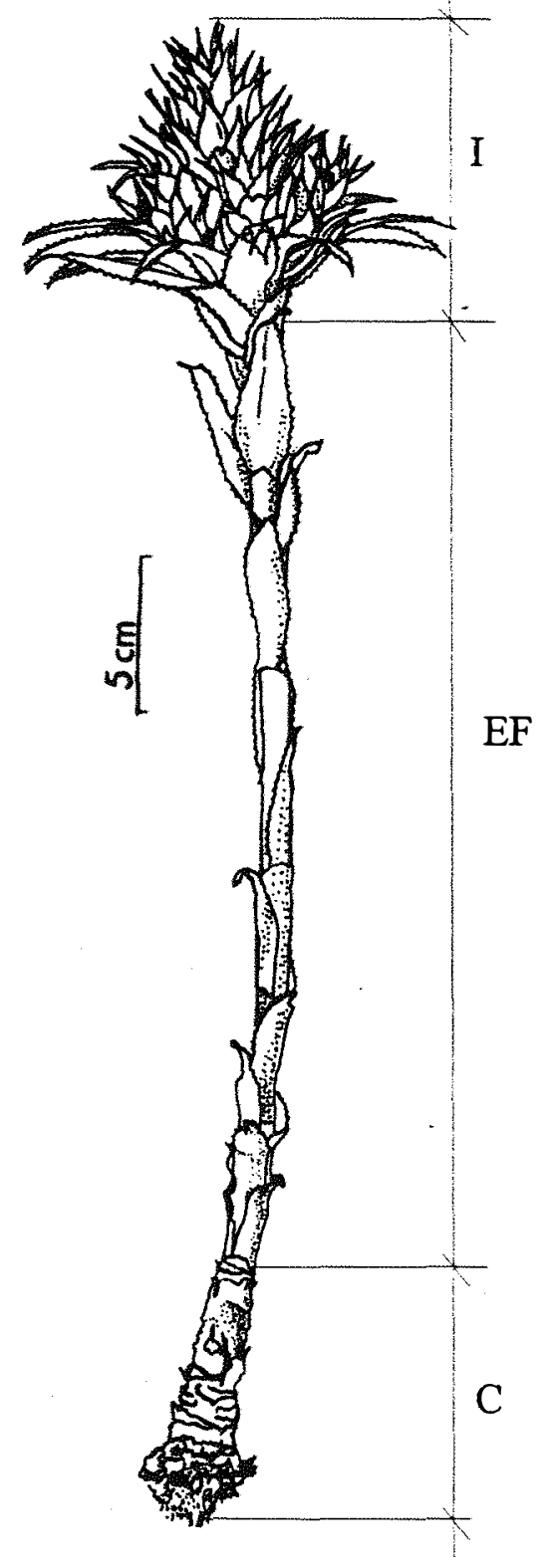

Figura 03. Desenho esquemático com a identificação do caule (C), escapo floral (EF) e inflorescência (I) da espécie $A$. fasciata Lindley (Baker), ESALQ-USP, Piracicaba, SP. 


\subsubsection{Fixação da planta no substrato em vaso}

A fixação das plantas no substrato contido no vaso foi avaliada individualmente através de notas variando de 1 a 3, seguindo-se o seguinte critério:

- nota 1: plantas firmemente fixas no substrato, sem apresentar nenhum movimento vertical ao movimentar o vaso,

- nota 2: plantas com leve movimento vertical ao movimentar o vaso, sem prejuízo na qualidade comercial e

- nota 3: plantas com movimento vertical significativo ao movimentar o vaso.

\subsubsection{Qualidade comercial}

$\mathrm{Na}$ avaliação visual da qualidade comercial das plantas adotou-se o sistema de notas variando de 1 a 3 , analisando-se as plantas individualmente, seguindo-se o seguinte critério:

- nota 1: plantas com ótima qualidade comercial, tanto na parte das folhas como na inflorescência;

- nota 2: plantas com boa qualidade comercial, tanto na parte das folhas como na inflorescência e

- nota 3: plantas com defeitos, sem condições de comercialização.

\subsection{Constituição dos tratamentos, delineamento experimental e análise estatística}

Os substratos foram formulados utilizando-se matérias primas em diferentes proporções, conforme a tabela 02. 
Tabela 02- Composição e proporção dos diferentes substratos utilizados no cultivo de A. fasciata em vaso, ESALQ-USP, Piracicaba, SP.

\begin{tabular}{|c|c|c|}
\hline substrato & composição & proporção volumétrica \\
\hline $\mathrm{Pi} / 2: 7: 1$ & casca de Pinus + turfa + perlita & $2: 7: 1$ \\
\hline $\mathrm{Pi} / 5: 4: 1$ & casca de Pinus + turfa + perlita & $5: 4: 1$ \\
\hline $\mathrm{Pi} / 8: 1: 1$ & casca de Pinus + turfa + perlita & $8: 1: 1$ \\
\hline $\mathrm{Eu} / 2: 7: 1$ & casca de Eucalyptus + turfa + perlita & 2:7:1 \\
\hline $\mathrm{Eu} / 5: 4: 1$ & casca de Eucalyptus + turfa + perlita & $5: 4: 1$ \\
\hline Eu/8:1:1 & casca de Eucalyptus + turfa + perlita & $8: 1: 1$ \\
\hline $\mathrm{Cx} / 2: 7: 1$ & coxim + turfa + perlita & $2: 7: 1$ \\
\hline $\mathrm{Cx} / 5: 4: 1$ & coxim + turfa + perlita & $5: 4: 1$ \\
\hline $\mathrm{Cx} / 8: 1: 1$ & coxim + turfa + perlita & $8: 1: 1$ \\
\hline Fc/2:7:1 & fibra de coco + turfa + perlita & $2: 7: 1$ \\
\hline Fc/5:4:1 & fibra de coco + turfa + perlita & $5: 4: 1$ \\
\hline Fc/8:1:1 & fibra de coco + turfa + perlita & $8: 1: 1$ \\
\hline $\mathrm{Xa} / 2: 7: 1$ & xaxim + turfa + perlita & $2: 7: 1$ \\
\hline$X a / 5: 4: 1$ & xaxim + turfa + perlita & $5: 4: 1$ \\
\hline $\mathrm{Xa} / \mathbf{8}: 1: 1$ & xaxim + turfa + perlita & $8: 1: 1$ \\
\hline
\end{tabular}

O delineamento experimental adotado foi o de blocos casualizados, conforme NOGUEIRA (1994) para todas as variáveis consideradas, com exceção de altura e diâmetro da planta, largura da terceira folha, número de folhas e diâmetro do colo que foi de blocos casualizados com parcelas subdivididas no tempo ("split plot in time"), conforme BANZATTO \& KRONKA (1995). Constou de 15 tratamentos e 4 blocos, em que cada parcela foi constituída por 8 plantas, totalizando 480 plantas. $\mathrm{Na}$ última avaliação, aos 435 dias, foram consideradas 6 plantas por parcela. Para as variáveis área foliar e massa seca da raiz foram tomadas 3 plantas por parcela. A escolha das plantas foi feita ao acaso, através de sorteio.

O esquema de análise de variância com aplicação do teste $\mathrm{F}$, para as variáveis altura, largura da terceira folha e maior diâmetro da planta, conforme BANZATTO \& KRONKA (1995), foi o que se segue: 


\begin{tabular}{|c|c|c|c|c|}
\hline causa da variação & GL & SQ & $\mathbf{Q M}$ & $\mathbf{F}$ \\
\hline tratamentos(S) & 14 & SQS & QMS & QMS/QMR(A) \\
\hline blocos & 3 & & & \\
\hline resíduo(A) & 42 & $\mathrm{SQR}(\mathrm{A})$ & QMR & \\
\hline (parcelas) & $(59)$ & SQP & & \\
\hline tempos(T) & 7 & SQT & QMT & QMT/QMresíduo(B) \\
\hline $\mathbf{S} \times \mathbf{T}$ & 98 & SQS x T & QMS x T & QMS x T/QMresíduo(B) \\
\hline resíduo(B) & 315 & SQ resíduo(B) & QM resíduo(B) & \\
\hline total & 479 & & & \\
\hline
\end{tabular}

$\mathrm{O}$ esquema da análise de variância com aplicação do teste $\mathrm{F}$ para a variável número de folhas, conforme BANZATTO \& KRONKA (1995), foi o que se segue:

\begin{tabular}{lcccc}
\hline causa da variação & GL & SQ & QM & F \\
\hline tratamentos(S) & 14 & SQS & QMS & QMS/QMR(A) \\
blocos & 3 & & & \\
resíduo(A) & 42 & SQR(A) & QMR & \\
\hline (parcelas) & $(59)$ & SQP & & \\
\hline tempos(T) & 5 & SQT & QMT & QMT/QMResíduo(B) \\
S x T & 70 & SQS x T & QMS x T & QMS x T/QMResíduo(B) \\
resíduo(B) & 245 & SQResíduo(B) & QMResíduo(B) & \\
\hline total & 379 & & & \\
\hline
\end{tabular}

$\mathrm{O}$ esquema da análise de variância com aplicação do teste $\mathrm{F}$ para a variável diâmetro do colo, conforme BANZATTO \& KRONKA (1995) foi o que se segue:

\begin{tabular}{|c|c|c|c|c|}
\hline causa da variação & GL & SQ & $\mathbf{Q M}$ & $\mathbf{F}$ \\
\hline tratamentos(S) & 14 & SQS & QMS & QMS/QMR(A) \\
\hline blocos & 3 & & & \\
\hline resíduo(A) & 42 & SQR(A) & QMR & \\
\hline (parcelas) & $(59)$ & $\mathrm{SQP}$ & & \\
\hline tempos(T) & 3 & $\overline{\mathrm{SQT}}$ & QMT & QMT/QMresíduo(B) \\
\hline$S \times T$ & 42 & SQS $\times \mathrm{T}$ & QMS x T & QMS x T/QMresíduo(B) \\
\hline resíduo(B) & 135 & SQ resíduo(B) & QM resíduo(B) & \\
\hline total & 239 & & & \\
\hline
\end{tabular}


O esquema da análise da variância, com aplicação do teste $F$, para as demais variáveis, conforme NOGUEIRA, (1994), foi o que se segue:

\begin{tabular}{lrlll}
\hline causa da variação & GL & SQ & QM & F \\
\hline tratamentos & 14 & SQTrat. & QMTrat. & QMTrat./QMResíduo \\
blocos & 3 & SQBlocos & QMBlocos & \\
resíduo & 42 & SQResíduo & QMResíduo & \\
\hline total & 59 & SQTotal & & \\
\hline
\end{tabular}

Para que os modelos de análise de variância, o teste $\mathrm{F}$ e de Tukey, e análise de regressão tenham validade, as seguintes pressuposições devem ser satisfeitas:

- $\quad$ homogeneidade de variâncias;

- independência de erros e

- $\quad$ erros com distribuição normal.

A fim de testar estas pressuposições, fez-se a análise exploratória de dados, através de teste de homogeneidade de variâncias, análise gráfica dos resíduos e diagrama de ramos e folhas. 


\section{RESULTADOS E DISCUSSÃO}

\subsection{Análise física e química dos substratos}

\subsubsection{Análise física}

A análise para a determinação das propriedades físicas dos substratos utilizados no experimento, com amostras colhidas no início do cultivo, segundo a metodologia desenvolvida por FRETZ et al. (1979) mostrou os resultados que constam na tabela 03, cujas médias aritméticas foram obtidas considerando-se três repetições.

Tabela 03. Características físicas dos substratos utilizados no experimento com a espécie A. fasciata Lindley (Baker), ESALQ-USP, Piracicaba, SP.

\begin{tabular}{|c|c|c|c|c|}
\hline substrato & $\begin{array}{c}\text { densidade } \\
(\text { g.ml }\end{array}$ & $\begin{array}{c}\text { espaço poroso } \\
\text { total } \\
\text { (ml) }\end{array}$ & $\begin{array}{l}\text { água retida na } \\
\text { capacidade de } \\
\text { campo }(\mathrm{ml})\end{array}$ & $\begin{array}{l}\text { espaço poroso } \\
\text { na capacidade } \\
\text { de campo }(\mathrm{ml})\end{array}$ \\
\hline $\mathrm{Pi} / 2: 7: 1$ & 0,30 & 133,67 & 105,60 & 28,07 \\
\hline Pi/5:4:1 & 0,29 & 137,67 & 104,42 & 33,25 \\
\hline Pi/8:1:1 & 0,27 & 118,67 & 75,42 & 43,24 \\
\hline Eu/2:7:1 & 0,31 & 148,67 & 127,54 & 21,12 \\
\hline Eu/5:4:1 & 0,33 & 137,17 & 125,45 & 11,71 \\
\hline Eu/8:1:1 & 0,44 & 99,00 & 87,21 & 11,79 \\
\hline $\mathrm{Cx} / 2: 7: 1$ & 0,34 & 132,00 & 106,34 & 25,66 \\
\hline$C x / 5: 4: 1$ & 0,32 & 129,36 & 100,65 & 28,71 \\
\hline Cx/8:1:1 & 0,30 & 136,67 & 79,01 & 21,16 \\
\hline Fc/2:7:1 & 0,31 & 121,33 & 109,51 & 11,82 \\
\hline Fc/5:4:1 & 0,26 & 104,33 & 82,14 & 22,19 \\
\hline Fe/8:1:1 & 0,07 & 152,67 & 16,24 & 32,09 \\
\hline $\mathrm{Xa} / 2: 7: 1$ & 0,27 & 145,83 & 126,99 & 18,84 \\
\hline $\mathrm{Xa} / 5: 4: 1$ & 0,20 & 120,33 & 107,65 & 12,68 \\
\hline $\mathrm{Xa} / 8: 1: 1$ & 0,17 & 108,33 & 79,37 & 28,97 \\
\hline
\end{tabular}




\subsubsection{Análise química}

A análise química dos substratos utilizados no experimento, segundo a metodologia seguida pelo Departamento de Solos e Nutrição de Plantas da ESALQUSP, resultou nos dados apresentados nas tabelas 04 e 05.

\subsection{Variáveis analisadas durante 0 crescimento}

\subsubsection{Altura e maior diâmetro da planta e largura da terceira folha}

$\mathrm{O}$ teste de Levene mostrou heterogeneidade de variâncias para as variáveis consideradas. A análise de resíduos e demais técnicas exploratórias indicaram que estas deveriam ser transformadas. Desta forma, as variáveis altura e maior diâmetro da planta e a largura da terceira folha foram transformadas em $\sqrt{x}$ (HOAGLIN et al., 1992).

A análise de variância com o teste $\mathrm{F}$ para as variáveis altura e maior diâmetro da planta e largura da terceira folha encontra-se na tabela 06.

Houve diferença significativa, pelo teste $F$, entre os substratos e a interação entre tempo de crescimento e substratos, ao nível $\alpha<0,01$, para todas as variáveis consideradas.

Os resultados da análise de variância da regressão polinomial, com desdobramento dos graus de liberdade dos tempos dentro de cada tratamento, mostraram que as regressões foram significativas para as variáveis altura, maior diâmetro da planta e largura da terceira folha. 


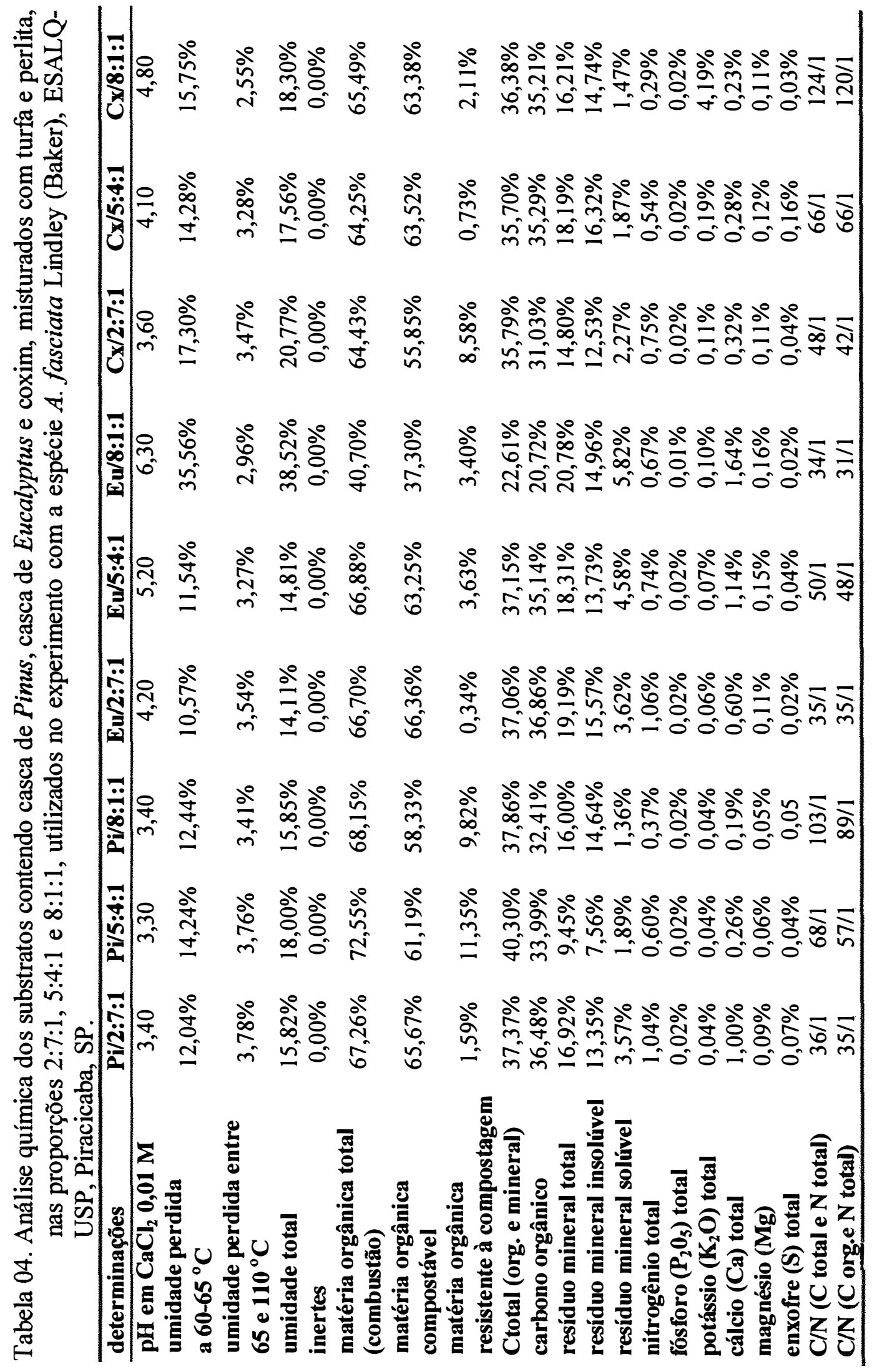




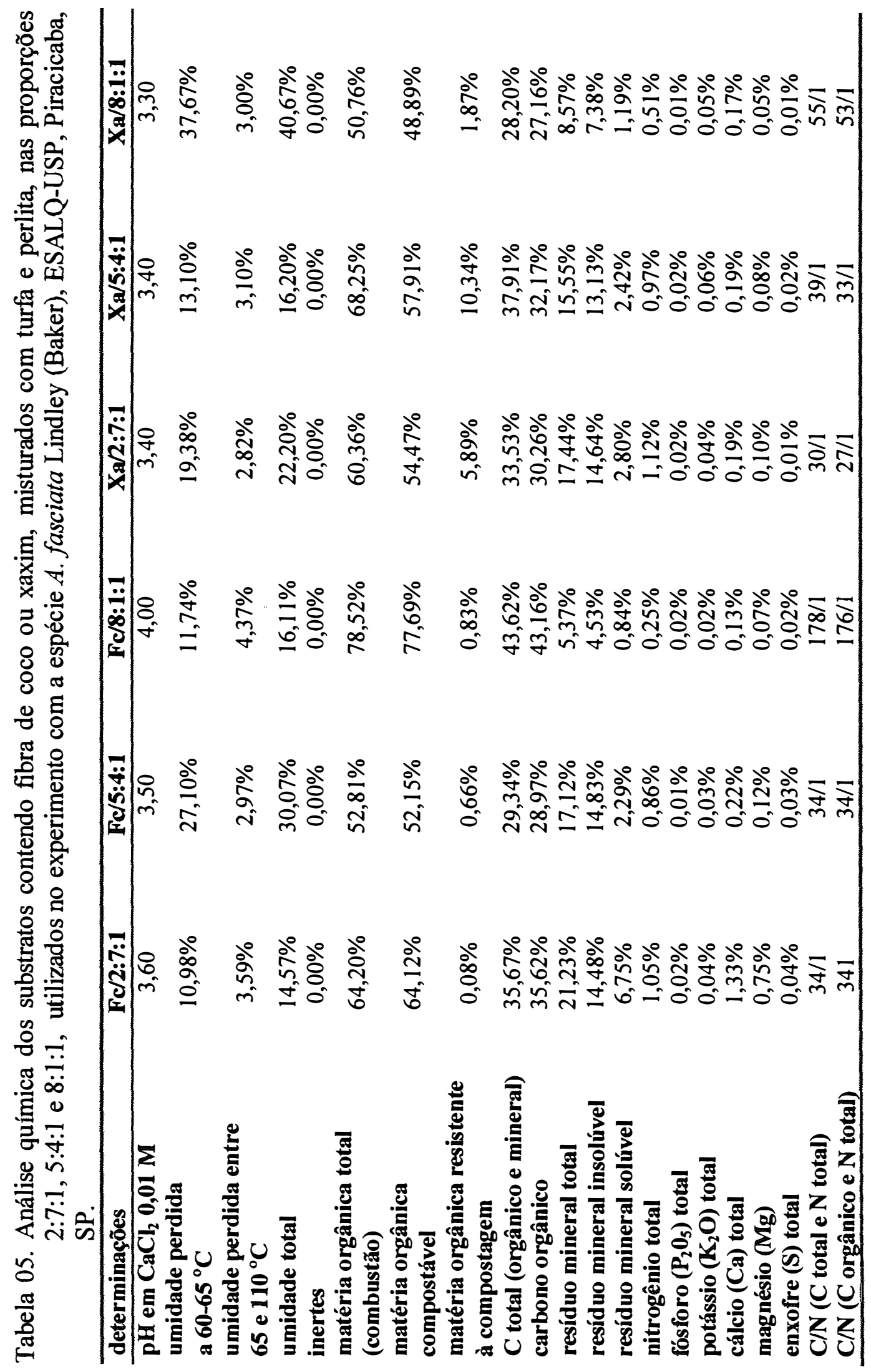


Tabela 06. Análise de variância e teste $\mathrm{F}$ para as variáveis altura, maior diâmetro e largura da terceira folha da espécie $A$. fasciata Lindley (Baker), ESALQUSP, Piracicaba, SP.

\begin{tabular}{|c|c|c|c|c|}
\hline \multirow{3}{*}{$\begin{array}{l}\text { causas da } \\
\text { variação }\end{array}$} & \multirow{3}{*}{ GL } & \multicolumn{3}{|c|}{ quadrados médios } \\
\hline & & \multicolumn{2}{|c|}{ planta } & \multirow{2}{*}{$\begin{array}{c}\text { largura da terceira } \\
\text { folba }^{T}\end{array}$} \\
\hline & & altura $^{\mathrm{T}}$ & maior diâmetro ${ }^{\mathrm{T}}$ & \\
\hline substratos(S) & 14 & $0,5590505^{* *}$ & $3,3540555^{* *}$ & $0,0456828^{* *}$ \\
\hline blocos & 3 & & & \\
\hline resíduo(A) & 42 & 0,0148768 & 0,0430155 & 0,0056081 \\
\hline (parcelas) & (59) & & & \\
\hline tempo(T) & 7 & $189,1224784^{* *}$ & $243,3803305^{* *}$ & $31,6032984^{* *}$ \\
\hline $\mathbf{S} \times \mathbf{T}$ & 98 & $0,0632931^{* *}$ & $0,2314168^{* *}$ & $0,0076078^{* *}$ \\
\hline resíduo(B) & 315 & 0,0125743 & 0,0153934 & 0,0024802 \\
\hline total & 479 & & & \\
\hline CV(A) \% & & 0,881 & 1,189 & 1,201 \\
\hline CV(B) \% & & 2,290 & 2,012 & 2,259 \\
\hline
\end{tabular}




\subsubsection{Altura da planta}

A variável altura da planta apresentou regressão cúbica significativa na maioria dos tratamentos. Nos tratamentos $\mathrm{Pi} / 5: 4: 1, \mathrm{Pi} / 8: 1: 1$ e Xa/8:1:1, as regressões cúbicas não foram significativas, optando-se pelo ajuste quadrático, por apresentar maior coeficiente de determinação. A figura 04 ilustra este comportamento.

As médias observadas nos tratamentos dentro dos tempos na variável altura da planta encontram-se na tabela 07.

No início, aos 5 dias do transplante, a altura das plantas nos diferentes substratos não apresentou diferença significativa entre si, mostrando que as mudas utilizadas foram uniformes na variável em questão.

Após 61 dias, o substrato Pinus, na proporção 5:4:1, se distinguiu dos demais, enquanto a mistura casca de Eucalyptus, na proporção 2:7:1, apresentou a menor média.

Já aos 117 dias, os substratos contendo xaxim ou casca de Pinus, em todas as proporções testadas, começaram a se destacar como as misturas com as melhores médias, enquanto os substratos constituídos de casca de Eucalyptus, coxim ou fibra de coco, na proporção 8:1:1, a evidenciarem as menores médias. Assim, aos 173 dias, os substratos com as melhores médias comportaram-se com a mesma tendência observada aos 117 dias e os substratos contendo casca de Eucalyptus ou fibra de coco, na proporção 2:7:1, começaram a destacar entre as maiores médias. As menores médias

continuaram a ser observadas nos substratos casca de Eucalyptus, coxim e fibra de coco, na proporção $8: 1: 1$.

Aos 229 dias foi observada a maior diferença entre as alturas das plantas $(36,19$ $27,04=9,15 \mathrm{~cm}$ ), sendo mantida a tendência mostrada a partir dos 117 dias: as menores médias nos substratos casca de Eucalyptus, coxim e fibra de coco, na proporção 8:1:1.

A partir de 285 dias após o transplante as diferenças entre as alturas das plantas começaram a estreitar. Aos 341 dias, os substratos formulados com xaxim ou casca de Pinus, em todas as proporções, casca de Eucalyptus, coxim ou fibra de coco, nas proporções 2:7:1, destacaram-se com as melhores médias de altura. Menores médias foram observadas, apenas, nos substratos casca de Eucalyptus, coxim e fibra de coco, na 

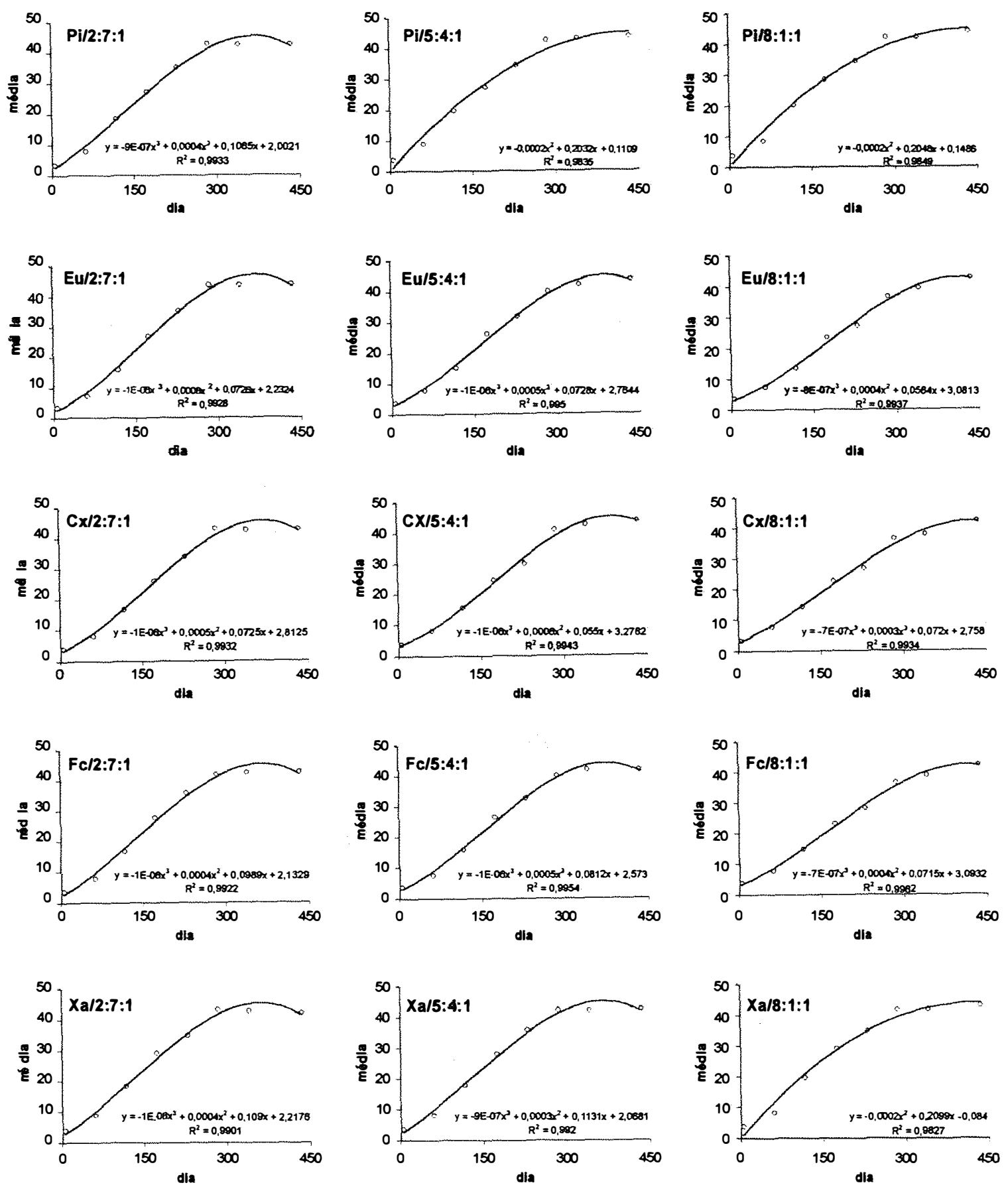

Figura 04. Médias observadas e funções ajustadas para a variável altura da planta, em função dos tempos dentro dos tratamentos, na espécie $A$. fasciata Lindley (Baker), ESALQ-USP, Piracicaba, SP. 


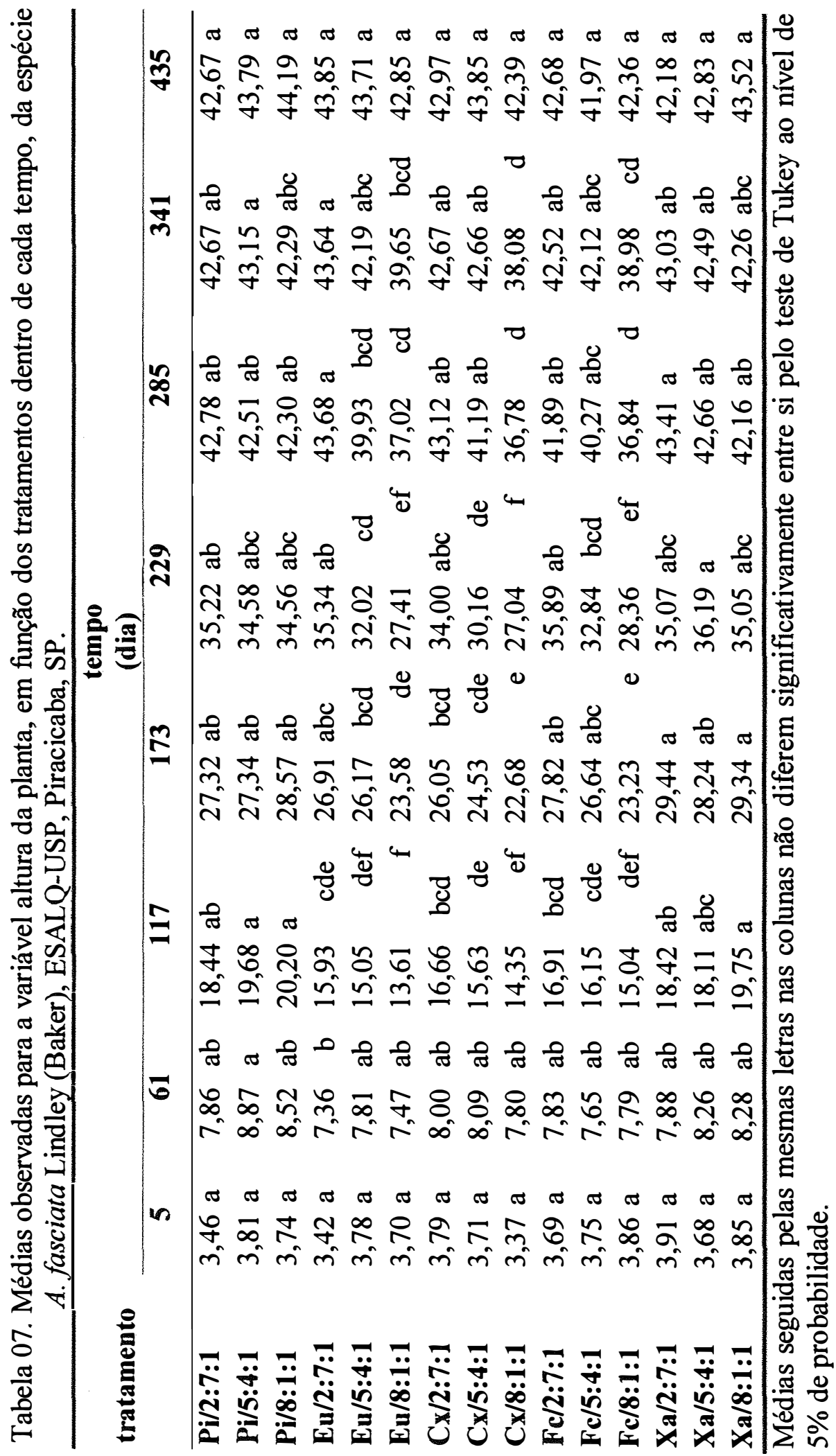


proporção 8:1:1. Ao final do experimento, as alturas se igualaram em todos os substratos considerados, não apresentando médias diferindo significativamente entre si.

\subsubsection{Maior diâmetro da planta}

A variável maior diâmetro da planta apresentou regressão linear, quadrática e cúbica significativa em todos os tratamentos. Optou-se pelo ajuste polinomial do $3^{\text {o }}$ grau por apresentar maior coeficiente de determinação. A figura 05 ilustra este comportamento.

As médias observadas nos tratamentos dentro dos tempos na variável maior diâmetro da planta encontram-se na tabela 08.

A variável maior diâmetro da planta não mostrou diferença significativa entre si aos cinco dias do transplante, mostrando que, assim como ocorreu para a altura, as mudas utilizadas eram uniformes no diâmetro. Até 61 dias, a variável maior diâmetro das plantas continuou a não apresentar diferenças significativas entre as médias dos tratamentos.

A partir de 117 dias após o transplante, os resultados mostraram que os tratamentos começaram a se diferenciar significativamente entre si. Evidenciaram como melhores médias, os tratamentos formulados com casca de Pinus ou xaxim, na proporção $8: 1: 1$, e Pi/5:4:1.

Aos 173 dias, os substratos contendo xaxim ou casca de Pinus, em todas as proporções, já se destacavam com as melhores médias de maior diâmetro da planta.

A partir do $229^{\circ}$. dia até o término do experimento, os substratos contendo xaxim ou casca de Pinus, em todas as proporções, e os substratos com casca de Eucalyptus, coxim ou fibra de coco, na proporção 2:7:1, destacaram-se com as maiores médias.

Os resultados mostraram ainda que os substratos confeccionados com casca de Eucalyptus ou coxim, exceto na formulação 2:7:1, começaram logo no início, aos 117 dias, a apresentarem as menores médias e, assim comportaram-se até o final do experimento. Provavelmente, a menor quantidade de turfa foi prejudicial ao crescimento em diâmetro da planta. 

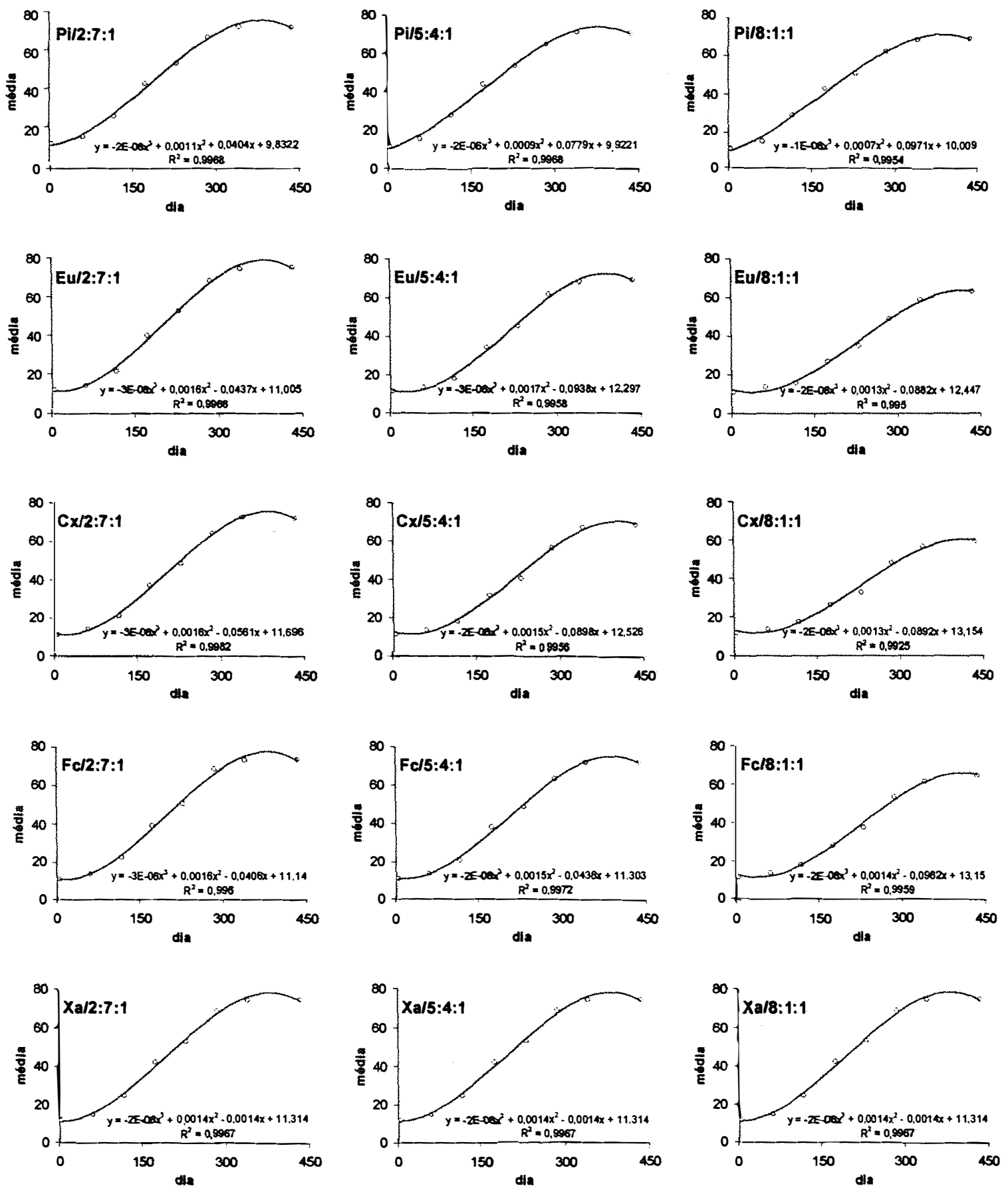

Fig. 05. Médias observadas e funções ajustadas para a variável maior diâmetro da planta, em função dos tempos dentro dos tratamentos, na espécie $A$. fasciata Lindley (Baker), ESALQ-USP, Piracicaba, SP. 


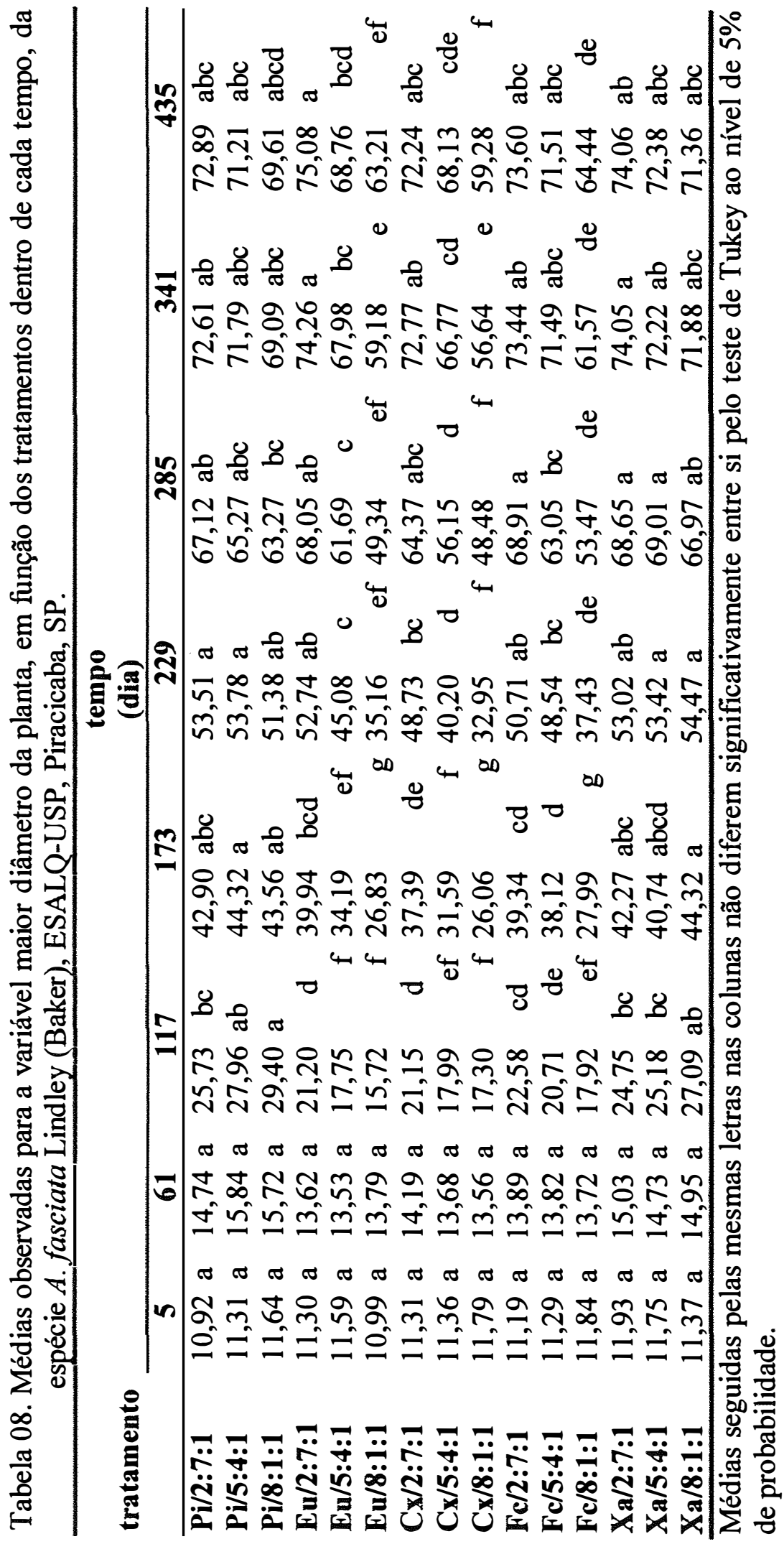




\subsubsection{Largura da terceira folha}

A variável largura da terceira folha apresentou regressão linear, quadrática e cúbica significativa em todos os tratamentos. Optou-se pelo ajuste polinomial do $3^{\mathrm{o}}$ grau por apresentarem maior valor de coeficiente de determinação $\left(R^{2}\right)$. A figura 06 ilustra este comportamento.

As médias observadas nos tratamentos dentro dos tempos na variável largura da terceira folha encontram-se na tabela 09.

Os resultados mostraram que, aos 5 dias, as médias dos tratamentos não diferiram significativamente entre si, indicando que as mudas utilizadas foram uniformes também nesta variável.

Este mesmo comportamento observado aos 5 dias, mantiveram-se nas observações do $61^{\circ}$ e $117^{\circ}$ dia.

Durante a avaliação no $173^{\circ}$ dia, notou-se que os substratos constituídos de xaxim ou casca de Pinus começaram, assim como na variável anterior, a se destacar no aumento da largura da terceira folha, porém a partir do $341^{\circ}$ dia observou-se tendência à uniformização. Ao atingir a fase de florescimento, ao final do experimento (435 dias), destacou-se o substrato Xa/5:4:1 com maior média e Fc/8:1:1 com menor média.

O substrato Fc/8:1:1 apresentou, durante todo o ciclo da cultura, uma das menores médias. 

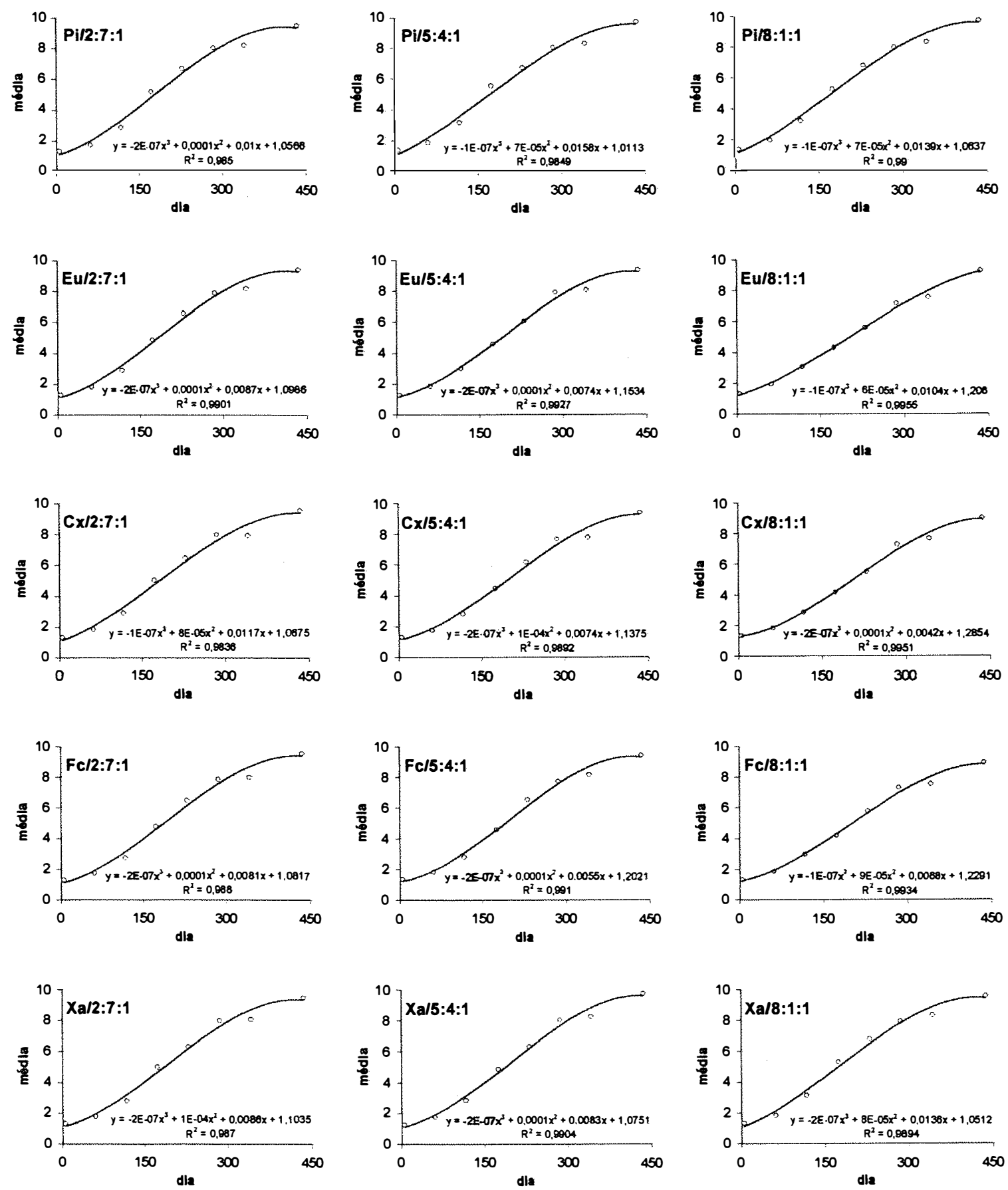

Figura 06. Médias observadas e funções ajustadas para a variável largura da terceira folha, em função dos tempos dentro dos tratamentos, na espécie $A$. fasciata Lindley (Baker), ESALQ-USP, Piracicaba, SP. 


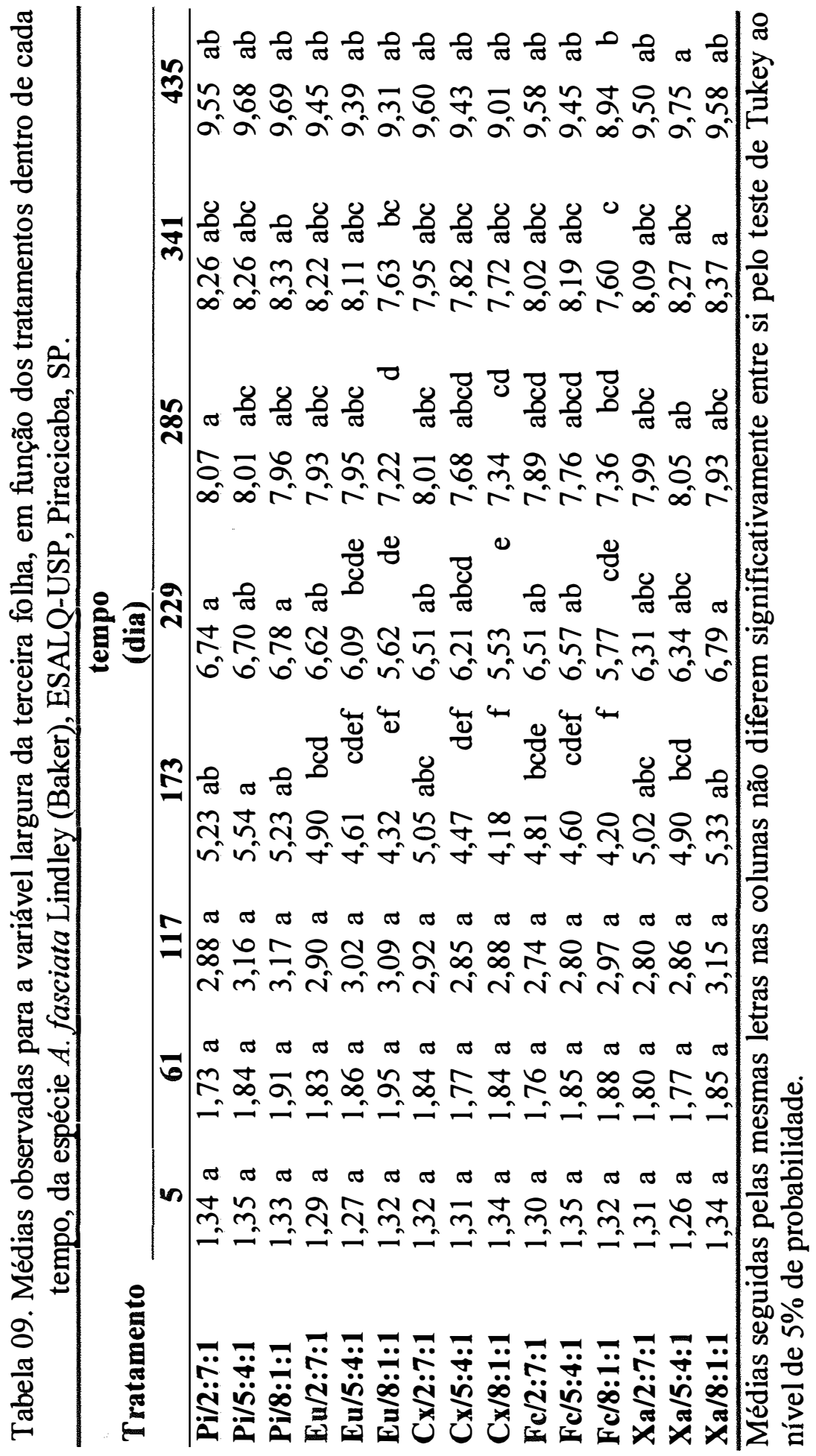




\subsubsection{Número de folhas e diâmetro do colo}

A análise de variância com o teste $\mathrm{F}$ para a variável número de folhas e diâmetro do colo encontra-se na tabela 10 .

Tabela 10. Análise de variância e teste $\mathrm{F}$ para as variáveis número de folhas e diâmetro do colo da espécie $A$. fasciata Lindley (Baker), ESALQ-USP, Piracicaba, SP.

\begin{tabular}{|c|c|c|c|c|}
\hline \multirow{2}{*}{$\begin{array}{l}\text { causas da } \\
\text { variação }\end{array}$} & \multicolumn{4}{|c|}{ quadrados médios } \\
\hline & GL & número de folhas & $\mathbf{G L}$ & diâmetro do colo \\
\hline substratos(S) & 14 & $8,9278245^{* *}$ & 14 & $0,2563830 * *$ \\
\hline blocos & 3 & & 3 & \\
\hline resíduo(A) & 42 & 0,4913372 & 42 & 0,0077313 \\
\hline (parcelas) & (59) & & (59) & \\
\hline tempo(T) & 5 & $867,8607385 * *$ & 3 & $20,2390478^{* *}$ \\
\hline$S \times T$ & 70 & $0,5738026 * *$ & 42 & $0,0112291 * *$ \\
\hline resíduo(B) & 225 & 0,1724477 & 135 & 0,0031752 \\
\hline total & 359 & & 239 & \\
\hline $\operatorname{CV}(\mathrm{A}) \%$ & & 2,424 & & 1,573 \\
\hline CV(B) $\%$ & & 3,518 & & 2,017 \\
\hline
\end{tabular}

Houve diferença significativa, pelo teste $F$, entre os substratos e a interação entre tempo de crescimento e substratos, ao nível $\alpha<0,01$ de significância, para todas as variáveis consideradas.

Os resultados da análise de variância da regressão polinomial, com desdobramento dos graus de liberdade dos tempos dentro de cada tratamento, mostraram que as regressões foram significativas para número de folhas e diâmetro do colo.

\subsubsection{Número de folhas}

$\mathrm{Na}$ variável número de folhas, as regressões lineares e cúbicas foram significativas em todos os tratamentos. Optou-se pelo ajuste polinomial do $3^{0}$ grau em todos os tratamentos, por apresentar maior valor de coeficiente de determinação. A figura 07 ilustŗa este comportamento. 

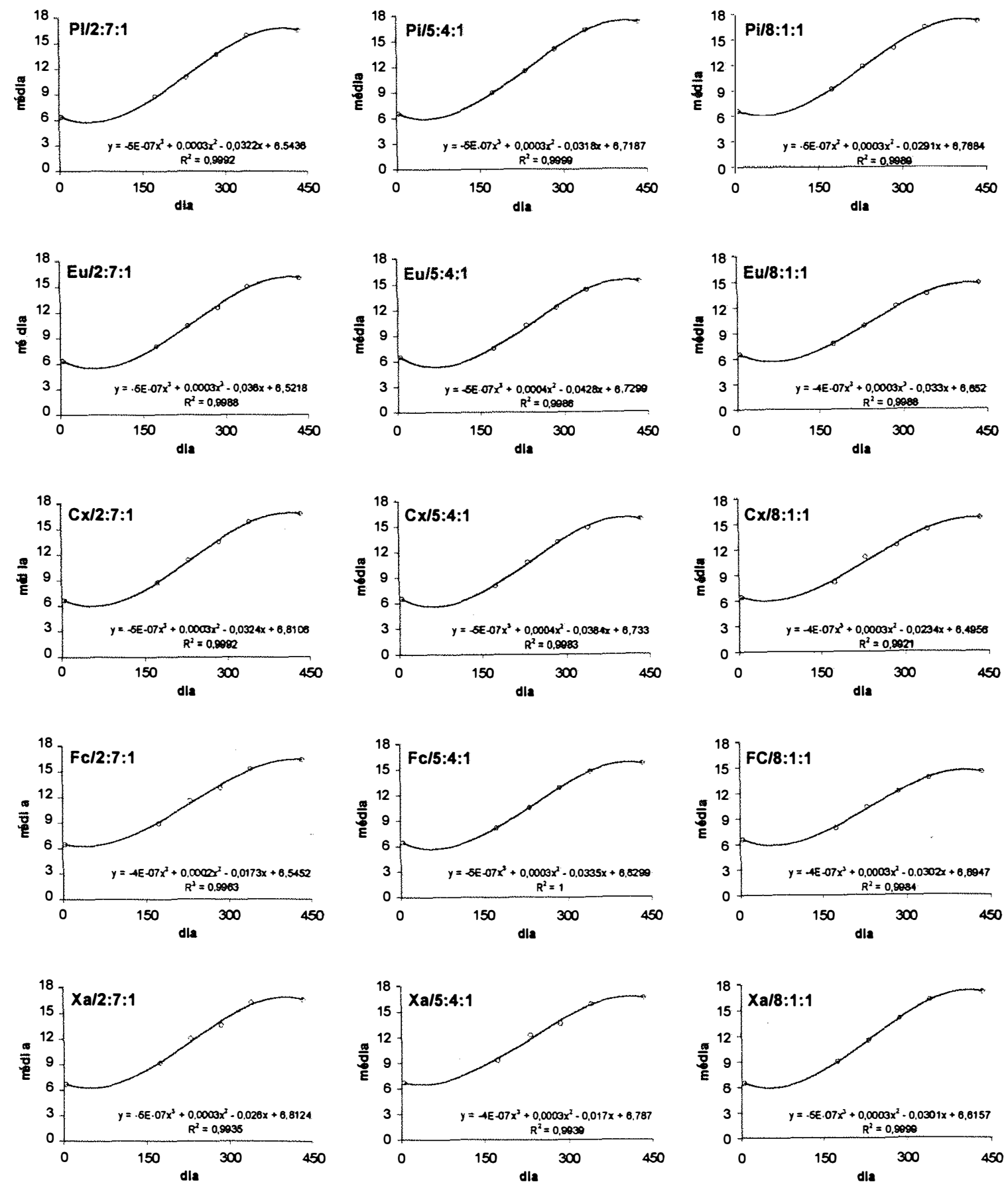

Figura 07. Médias observadas e funções ajustadas para a variável número de folhas, em função dos tempos para cada tratamento, na espécie $A$. fasciata Lindley (Baker), ESALQ-USP, Piracicaba, SP. 
As médias observadas para os tempos dentro dos tratamentos na variável número de folhas encontra-se na tabela 11.

Os resultados mostraram que o número de folhas no início do experimento, aos 5 dias, não apresentou médias com diferenças significativas entre os tratamentos, conforme era esperado, mostrando a uniformidade das mudas quando do transplante.

Aos 173 dias do transplante, os tratamentos formulados com xaxim ou casca de Pinus, em todas as proporções testadas, e os substratos com fibra de coco ou coxim, na proporção 2:7:1, destacaram-se com as melhores médias de número de folha.

Este comportamento foi observado em todos os outros períodos considerados durante o experimento $(229,285,341$ e 435 dias $)$.

As menores médias de número de folhas, em todos os períodos considerados, foram para os substratos contendo fibra de coco ou casca de Eucalyptus, na proporção $8: 1: 1$

\subsubsection{Diâmetro do colo}

$\mathrm{Na}$ variável diâmetro do colo, as regressões lineares e quadráticas foram significativas em todos os tratamentos. Nos tratamentos formulados com coxim, em todas as proporções, e fibra de coco, nas proporções $2: 7: 1$ e 8:1:1, as regressões cúbicas foram significativas, optando-se pelo ajuste polinomial cúbico nestes tratamentos. Os demais tratamentos foram ajustados pelo polinômio do $2^{\underline{0}}$ grau por apresentarem maior coeficiente de determinação. A figura 08 ilustra este comportamento.

As médias observadas nos tratamentos dentro dos tempos na variável maior diâmetro de colo foram anotadas a partir do $173^{\circ}$ dia, e encontram-se na tabela 12 .

Os resultados mostraram que no $173^{\circ}$ dia, os substratos compostos de xaxim ou casca de Pinus, em todas as proporções, não diferindo significativamente entre si, apresentaram as maiores médias de diâmetro de colo. As menores médias foram observadas nos substratos compostos de casca de Eucalyptus, fibra de coco ou coxim, na proporção 8:1:1, e casca de Eucalyptus ou coxim, na proporção 5:4:1. 


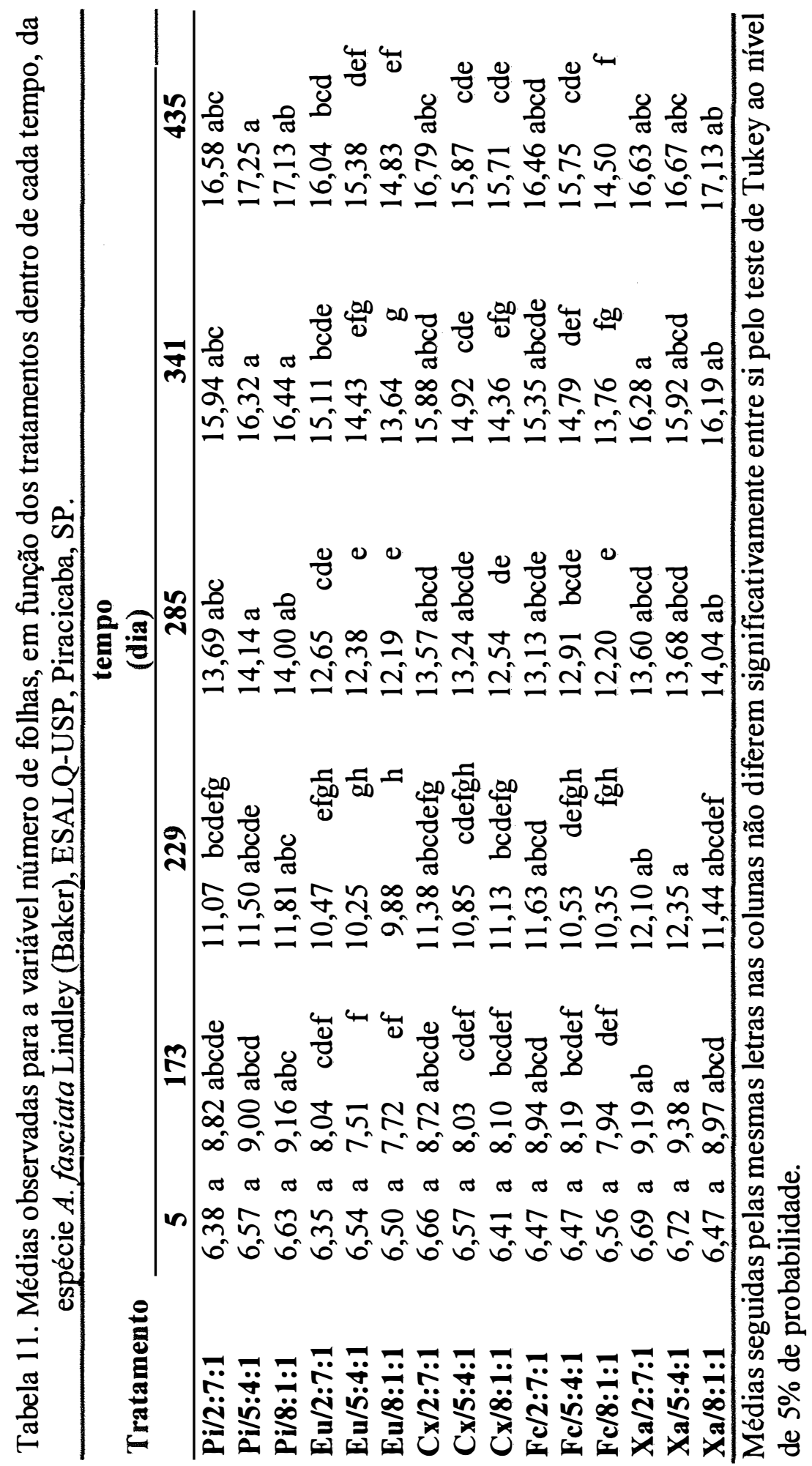



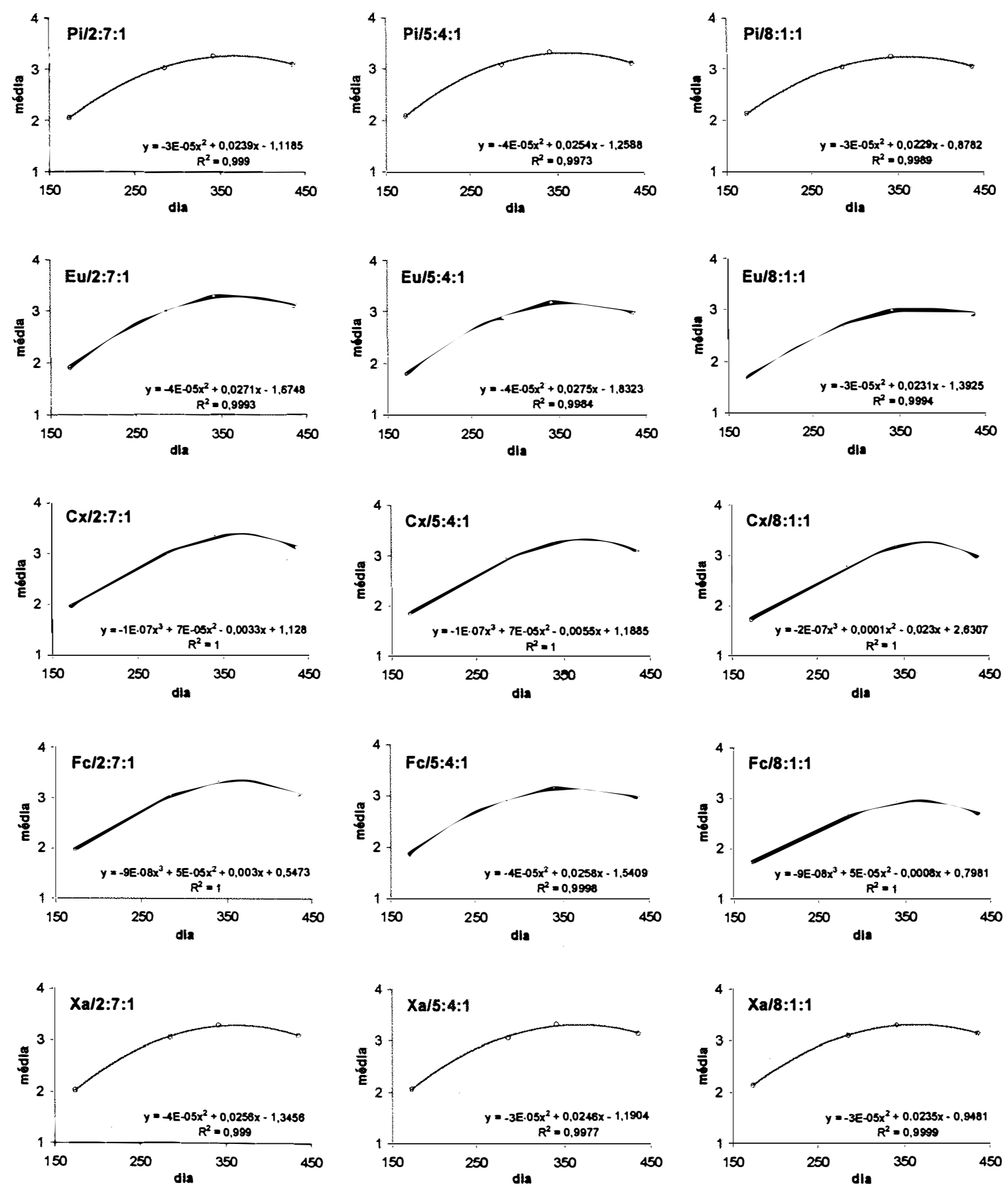

Figura 08. Médias observadas e funções ajustadas para a variável diâmetro do colo, em função dos tempos para cada tratamento, na espécie A. fasciata Lindley (Baker), ESALQ-USP, Piracicaba, SP. 
Tabela 12. Médias observadas para a variável diâmetro do colo, em função dos tratamentos dentro de cada tempo, da espécie $A$. fasciata Lindley (Baker), ESALQ-USP, Piracicaba, SP.

\begin{tabular}{|c|c|c|c|c|}
\hline \multirow[t]{2}{*}{ tratamento } & \multicolumn{4}{|c|}{$\begin{array}{c}\text { tempo } \\
\text { (dia) }\end{array}$} \\
\hline & 173 & 285 & 341 & 435 \\
\hline $\mathrm{Pi} / 2: 7: 1$ & $2,05 \mathrm{abc}$ & $3,03 \mathrm{abc}$ & $3,26 \mathrm{abc}$ & $3,10 \mathrm{abc}$ \\
\hline $\mathrm{Pi} / 5: 4: 1$ & $2,09 \mathrm{ab}$ & $3,09 \mathrm{ab}$ & $3,35 \mathrm{a}$ & $3,12 \mathrm{abc}$ \\
\hline Pi/8:1:1 & $2,13 \mathrm{ab}$ & $3,04 \mathrm{abc}$ & $3,24 \mathrm{abc}$ & $3,05 \mathrm{abcd}$ \\
\hline Eu/2:7:1 & 1,92 cde & $3,04 \mathrm{abc}$ & $3,31 \mathrm{abc}$ & $3,14 \mathrm{ab}$ \\
\hline Eu/5:4:1 & 1,80 efg & $2,91 \mathrm{~cd}$ & $3,19 a b c$ & 2,99 bcd \\
\hline Eu/8:1:1 & $1,71 \quad \mathrm{~g}$ & $2,72 \quad \mathrm{e}$ & $2,99 \quad \mathrm{~d}$ & $2,93 \mathrm{~d}$ \\
\hline $\mathrm{Cx} / 2: 7: 1$ & 1,98 bcd & $3,03 \mathrm{abc}$ & 3,35 a & $3,16 \mathrm{a}$ \\
\hline$C x / 5: 4: 1$ & 1,86 defg & $2,93 \mathrm{bcd}$ & $3,27 \mathrm{abc}$ & $3,10 \mathrm{abc}$ \\
\hline $\mathrm{Cx} / 8: 1: 1$ & $1,74 \quad \mathrm{fg}$ & 2,77 de & $3,17 b c$ & $2,99 \mathrm{bcd}$ \\
\hline Fc/2:7:1 & 1,97 bcd & $3,04 \mathrm{abc}$ & $3,32 \mathrm{ab}$ & 3,09 abcd \\
\hline Fc/5:4:1 & 1,87 def & $2,93 \mathrm{~cd}$ & $3,15 \quad c$ & $2,98 \mathrm{~cd}$ \\
\hline Fc/8:1:1 & $1,74 \quad \mathrm{fg}$ & 2,66 e & $2,92 \quad d$ & $2,70 \quad \mathrm{e}$ \\
\hline $\mathrm{Xa} / 2: 7: 1$ & $2,03 \mathrm{abc}$ & $3,06 \mathrm{abc}$ & $3,30 \mathrm{abc}$ & $3,10 \mathrm{abc}$ \\
\hline $\mathrm{Xa} / 5: 4: 1$ & $2,07 \mathrm{abc}$ & $3,07 \mathrm{abc}$ & $3,33 \mathrm{ab}$ & $3,16 \mathrm{a}$ \\
\hline $\mathrm{Xa} / 8: 1: 1$ & $2,15 \mathrm{a}$ & $3,11 \mathrm{a}$ & $3,30 \mathrm{abc}$ & $3,14 \mathrm{ab}$ \\
\hline
\end{tabular}

Médias seguidas pelas mesmas letras nas colunas não diferem significativamente entre si pelo teste de Tukey, ao nível de $5 \%$ de probabilidade.

No $285^{\circ}$ dia, observou-se que os substratos formulados com xaxim ou casca de Pinus, em todas as proporções, continuaram a se destacar entre as médias de diâmetro do colo. Sobressaíram, também, entre as melhores médias, os substratos casca de Eucalyptus, fibra de coco e coxim, nas proporções 2:7:1. Os substratos contendo casca de Eucalyptus, fibra de coco ou coxim, na proporção 8:1:1, continuaram a apresentar as menores médias.

Assim, entre o $341^{\circ}$ e $435^{\circ}$ dia, os substratos formulados com xaxim ou casca de Pinus, em todas as proporções consideradas no experimento, e os substratos contendo casca de Eucalyptus, fibra de coco ou coxim, na proporção 2:7:1, continuaram a apresentar as melhores médias de diâmetro de colo e não diferiram significativamente entre si. No período considerado, as menores médias foram observadas nos substratos contendo casca de Eucalyptus ou fibra de coco, na proporção 8:1:1. 
A observação dos resultados gráficos, figura 08 , mostra que todos os tratamentos tenderam a diminuir o diâmetro do colo ao final do experimento. Isto se deve à perda das folhas senís, diminuindo o diâmetro do colo. Observou-se que, após a aplicação do indutor floral, acelerou-se a senescência das folhas baixeiras.

\subsection{Variáveis analisadas no florescimento}

Para a análise dos resultados foram consideradas as variáveis da parte aérea vegetativa, da inflorescência, da massa seca e, da qualidade comercial e fixação da planta no substrato em vaso. As variáveis em questão não tiveram necessidade de transformação de dados, enquanto que a qualidade comercial e a fixação da planta no substrato em vaso, avaliadas através do critério de notas, apresentaram heterogeneidade irregular de variância, sendo, portanto, analisadas por estatística não-paramétrica.

\subsubsection{Parte aérea vegetativa}

Foram tomadas como variáveis da parte aérea vegetativa a folha com maior largura, diâmetro da planta e a área foliar.

$\mathrm{O}$ resumo da análise de variância e teste $\mathrm{F}$, com os graus de liberdade e quadrados médios para as variáveis em questão, encontra-se na tabela 13. Pelos resultados obtidos, verificou-se que houve efeito de tratamentos em todas as variáveis da parte aérea vegetativa ao nível $\alpha<0,01$ de significância. 
Tabela 13. Análise de variância e teste $F$ para as variáveis da parte aérea da planta, considerando-se folha com maior largura, diâmetro da planta e área foliar da espécie $A$. fasciata Lindley (Baker), ESALQ-USP, Piracicaba, SP.

\begin{tabular}{|c|c|c|c|c|}
\hline \multirow[b]{2}{*}{ causas da variação } & \multirow[b]{2}{*}{ GL } & \multicolumn{3}{|c|}{ quadrados médios } \\
\hline & & $\begin{array}{c}\text { folha com } \\
\text { maior largura }\end{array}$ & $\begin{array}{l}\text { diâmetro } \\
\text { da planta }\end{array}$ & área foliar \\
\hline blocos & 3 & & & \\
\hline tratamentos & 14 & $0,2420936 * *$ & $60,8050791 * *$ & $1525388,859379 * *$ \\
\hline resíduo & 42 & 0,0433657 & 7,1778377 & 60527,153208 \\
\hline total & 59 & & & \\
\hline $\begin{array}{l}\text { coeficiente de } \\
\text { variação }(\%)\end{array}$ & & 2,129 & 3,996 & 4,900 \\
\hline \multicolumn{5}{|c|}{ F $=$ significativo pelo teste $\mathrm{F}$ ao nível de $1 \%$ de probabilidade $(\alpha<0,01)$} \\
\hline
\end{tabular}

\subsubsection{Folha com maior largu ra}

Os resultados mostraram que apenas os substratos contendo nas suas formulações casca de Eucalyptus ou fibra de coco, na proporção 8:1:1, diferiram significativamente entre si dos demais tratamentos na variável folha com maior largura. Estes substratos com as menores proporções de turfa $(10 \%)$ mostraram as menores médias.

Notou-se que os substratos formulados com xaxim, casca de Pinus ou Eucalyptus, em todas as proporções consideradas no experimento (2:7:1, 5:4:1 e 8:1:1), proporcionaram folhas com larguras semelhantes, independendo da quantidade crescente de xaxim, casca de Pinus ou Eucalyptus ou, ainda, inversamente, da quantidade decrescente de turfa presente nos substratos.

Verificou-se também que os substratos com fibra de coco ou coxim, nas proporções 2:7:1 e 5:4:1, apresentaram médias que não diferiram significativamente entre si, indicando que estes substratos mostraram o mesmo desempenho quando as proporções de turfa foram 40 ou $70 \%$. 
Uma das características que confere qualidade no porte da espécie $A$. fasciata e muito valorizada durante a comercialização, é a largura das folhas, que também foi relatado por REITZ (1983), quando comentou sobre a utilidade como planta omamental desta espécie em particular.

Tabela 14. Médias da folha com maior largura, diâmetro da planta e área foliar da espécie $A$. fasciata Lindley (Baker), ESALQ-USP, Piracicaba, SP.

\begin{tabular}{|c|c|c|c|}
\hline tratamento & $\begin{array}{l}\text { folha com maior } \\
\text { largura } \\
\text { (cm) }\end{array}$ & $\begin{array}{c}\text { diâmetro } \\
\text { da planta } \\
\text { (cm) }\end{array}$ & $\begin{array}{c}\text { área foliar } \\
\left(\mathrm{cm}^{2}\right)\end{array}$ \\
\hline $\mathrm{Xa} / 5: 4: 1$ & $10,07 \mathrm{a}$ & $69,73 \mathrm{ab}$ & $5.489,34 \mathrm{ab}$ \\
\hline Pi/5:4:1 & 9,99ab & $68,08 \mathrm{ab}$ & $5.693,14 \mathrm{a}$ \\
\hline $\mathrm{Xa} / \mathbf{8}: 1: 1$ & $9,95 \mathrm{ab}$ & $67,10 \mathrm{abc}$ & $5.711,75 \mathrm{a}$ \\
\hline Pi/8:1:1 & $9,94 \mathrm{ab}$ & $66,82 \mathrm{abc}$ & $5.471,10 \mathrm{ab}$ \\
\hline Pi/2:7:1 & $9,94 \mathrm{ab}$ & $69,36 \mathrm{ab}$ & $5.350,86 \mathrm{abc}$ \\
\hline Fc/2:7:1 & $9,93 \mathrm{ab}$ & $69,66 \mathrm{ab}$ & $5.306,46 \mathrm{abcd}$ \\
\hline Cx/2:7:1 & $9,90 \mathrm{ab}$ & $69,31 \mathrm{ab}$ & $5.390,76 \mathrm{abc}$ \\
\hline$E u / 2: 7: 1$ & $9,89 \mathrm{ab}$ & $72,39 \mathrm{a}$ & $5.231,62 \mathrm{abcd}$ \\
\hline $\mathrm{Xa} / 2: 7: 1$ & $9,80 \mathrm{ab}$ & $70,28 \mathrm{a}$ & $5.352,55 \mathrm{abc}$ \\
\hline Cx/5:4:1 & $9,72 \mathrm{ab}$ & $66,29 a b c$ & $4.900,37 \mathrm{bcd}$ \\
\hline Fc/5:4:1 & $9,70 \mathrm{ab}$ & $68,21 \mathrm{ab}$ & $4.792,13 \mathrm{~cd}$ \\
\hline Eu/5:4:1 & $9,70 \mathrm{ab}$ & $67,02 \mathrm{abc}$ & $4.689,81$ \\
\hline Cx/8:1:1 & $9,54 a b c$ & $57,53 \quad d$ & $4.124,16$ \\
\hline Eu/8:1:1 & $9,53 \mathrm{bc}$ & $60,53 \mathrm{~cd}$ & $4.018,03$ \\
\hline Fc/8:1:1 & $9,11 \quad \mathrm{c}$ & $63,42 \mathrm{bcd}$ & $3.788,19$ \\
\hline média geral & 9,78 & 67,05 & 5020,69 \\
\hline dms (5\%) & 0,5309 & 6,830 & 627,2348 \\
\hline
\end{tabular}

Médias seguidas pelas mesmas letras, não diferem significativamente entre si pelo teste de Tukey ao nível de $5 \%$ de probabilidade.

\subsubsection{Diâmetro da planta}

Os resultados mostraram que os substratos formulados com xaxim ou casca de Pinus, em todas as proporções testadas, e os substratos constituídos de fibra de coco, casca de Eucalyptus e coxim, nas proporções 2:7:1 e 5:4:1, apresentaram as melhores médias, não diferindo significativamente entre si na variável diâmetro da planta. 
Os substratos formulados com fibra de coco, casca de Eucalyptus ou coxim, na proporção 8:1:1, mostraram as menores médias, não diferindo significativamente entre si.

Podemos, ainda, inferir que os substratos Eu/2:7:1 e Xa/2:7:1 mostraram tendência de se destacarem entre as maiores médias na variável diâmetro da planta.

\subsubsection{3. Área foliar}

Da análise dos resultados observou-se que os substratos formulados com xaxim ou casca de Pinus, em todas as proporções pesquisadas no experimento, e casca de Eucalyptus, fibra de coco ou coxim, nas proporções 2:7:1, apresentaram as melhores médias, não diferindo significativamente entre si na variável área foliar.

Os substratos $\mathrm{Xa} / 8: 1: 1$ e $\mathrm{Pi} / 5: 4: 1$ apresentaram tendência de mostrar as melhores médias de área foliar.

Seguiram-se substratos contendo casca de Eucalyptus, fibra de coco ou coxim, na proporção 5:4:1, ocupando uma posição intermediária na variável área foliar.

Apresentaram as menores médias na variável área foliar, os substratos que tinham na composição casca de Eucalyptus, fibra de coco ou coxim, na proporção 8:1:1.

\subsubsection{Medidas da inflorescência}

Foram tomadas como medidas deste item, o maior diâmetro, comprimento e número de ramos da inflorescência.

$\mathrm{O}$ resumo da análise de variância e teste $\mathrm{F}$, com os graus de liberdade e quadrados médios para as variáveis da inflorescência encontra-se na tabela 15. Pelos resultados obtidos, verificou-se que houve efeito de tratamentos sobre todas as variáveis da inflorescência ao nível $\alpha<0,01$ de significância.

Aplicou-se o teste de Tukey, ao nível $\alpha=0,05$ de significância, para detectar diferenças entre os tratamentos nas variáveis que compõem as medidas da inflorescência, cujas médias encontram-se na tabela 16 . 
Tabela 15. Análise de variância e teste $F$ para as variáveis da inflorescência, considerando-se o maior diâmetro, altura e número de ramos da inflorescência da espécie $A$. fasciata Lindley (Baker), ESALQ-USP, Piracicaba, SP.

\begin{tabular}{|c|c|c|c|c|}
\hline \multirow[b]{2}{*}{ causas da variação } & \multirow[b]{2}{*}{ GL } & \multicolumn{3}{|c|}{ quadrados médios } \\
\hline & & $\begin{array}{c}\text { maior } \\
\text { diâmetro } \\
(\mathrm{cm}) \\
\end{array}$ & $\begin{array}{l}\text { comprimento } \\
\text { (cm) }\end{array}$ & $\begin{array}{l}\text { número de } \\
\text { ramos } \\
\text { (unidade) }\end{array}$ \\
\hline blocos & 3 & & & \\
\hline tratamentos & 14 & $176,3153615^{* *}$ & $27,1643716^{* *}$ & $2,5209978 * *$ \\
\hline resíduo & 42 & 49,1669409 & 8,3060997 & 0,8037896 \\
\hline total & 59 & & & \\
\hline $\begin{array}{l}\text { coeficiente de } \\
\text { va riação }(\%)\end{array}$ & & 5,344 & 3,772 & 16,701 \\
\hline
\end{tabular}

\subsubsection{Maior diâmetro da inflorescência}

Os resultados mostraram que apenas as formulações $\mathrm{Xa} / 2: 7: 1$ e $\mathrm{Fc} / 8: 1: 1$ diferiram significativamente dos demais tratamentos.

Os substratos formulados com casca de Pinus, casca de Eucalyptus ou coxim, em todas as proporções consideradas no experimento, $\mathrm{Xa} / 5: 4: 1, \mathrm{Xa} / 8: 1: 1, \mathrm{Fc} / 2: 7: 1 \mathrm{e}$ Fc/5:4:1 apresentaram médias que não diferiram significativamente entre si na variável maior diâmetro da inflorescência, o que mostra bastante uniformidade em relação à variável considerada.

$\mathrm{O}$ substrato $\mathrm{Eu} / 2: 7: 1$ apresentou a tendência de mostrar a melhor média, seguidos de $\mathrm{Pi} / 5: 4: 1$ e $\mathrm{Cx} / 2: 7: 1$. 
Tabela 16. Médias do maior diâmetro, comprimento e número de ramos da inflorescência da espécie A. fasciata Lindley (Baker), ESALQ-USP, Piracicaba, SP.

\begin{tabular}{|c|c|c|c|}
\hline \multirow[t]{2}{*}{ tratamentos } & \multicolumn{3}{|c|}{ inflorescência } \\
\hline & $\begin{array}{c}\text { maior diâmetro } \\
(\mathrm{mm})\end{array}$ & $\begin{array}{c}\text { comprimento } \\
(\mathrm{mm})\end{array}$ & $\begin{array}{c}\text { número de ramos } \\
\text { (unidade) }\end{array}$ \\
\hline $\mathrm{Eu} / 2: 7: 1$ & $141,91 \mathrm{a}$ & $80,22 \mathrm{a}$ & $6,79 a$ \\
\hline $\mathrm{Pi} / 5: 4: 1$ & $138,30 \mathrm{ab}$ & $77,14 \mathrm{ab}$ & $6,12 a b$ \\
\hline$C x / 2: 7: 1$ & $137,90 \mathrm{ab}$ & 77,65 a & $5,92 \mathrm{abc}$ \\
\hline $\mathrm{Pi} / \mathbf{8}: 1: 1$ & $136,28 \mathrm{abc}$ & $75,42 a b$ & $5,87 \mathrm{abc}$ \\
\hline Fc/2:7:1 & $135,52 \mathrm{abc}$ & $76,47 \mathrm{ab}$ & $5,71 \mathrm{abc}$ \\
\hline $\mathrm{Xa} / 5: 4: 1$ & $134,72 a b c$ & $79,52 \mathrm{a}$ & $6,04 a b$ \\
\hline Cx/5:4:1 & $134,43 a b c$ & $74,57 \mathrm{ab}$ & $5,53 \mathrm{abc}$ \\
\hline Eu/5:4:1 & $133,80 a b c$ & $78,50 \mathrm{a}$ & $5,88 \mathrm{abc}$ \\
\hline Fc/5:4:1 & $128,38 a b c$ & $75,40 a b$ & $4,79 a b c$ \\
\hline $\mathrm{Pi} / 2: 7: 1$ & $127,60 a b c$ & $77,08 \mathrm{ab}$ & $5,21 \mathrm{abc}$ \\
\hline $\mathrm{Xa} / \mathbf{8}: 1: 1$ & $126,91 \mathrm{abc}$ & $75,28 \mathrm{ab}$ & $4,92 a b c$ \\
\hline Eu/8:1:1 & $126,03 \mathrm{abc}$ & $78,68 \mathrm{a}$ & $4,84 \mathrm{abc}$ \\
\hline $\mathrm{Cx} / 8: 1: 1$ & $124,16 a b c$ & $70,09 \mathrm{~b}$ & $4,82 a b c$ \\
\hline $\mathrm{Xa} / 2: 7: 1$ & $123,77 b c$ & $77,18 \mathrm{ab}$ & $4,37 \mathrm{bc}$ \\
\hline Fc/8:1:1 & $118,47 \quad \mathrm{c}$ & $73,00 \mathrm{ab}$ & $3,73 \quad \mathrm{c}$ \\
\hline média geral & 131,21 & 76,42 & 5,37 \\
\hline dms (5\%) & 17,87688 & 7,34774 & 2,28574 \\
\hline
\end{tabular}

Médias seguidas pelas mesmas letras, não diferem significativamente entre si pelo teste de Tukey ao nível de $5 \%$ de probabilidade.

\subsubsection{Comprimento da inflorescência}

Os resultados mostraram que a maioria dos substratos apresentou a variável comprimento da inflorescência com médias que não diferiram signficativamente entre si, com exceção do substrato $\mathrm{Cx} / 8: 1: 1$, com a menor média observada, provavelmente, por apresentar menor proporção de turfa em sua composição.

Notou-se uniformidade entre a quase totalidade dos tratamentos, também para esta variável.

Podemos, ainda, inferir que os substratos Eu/2:7:1, Xa/5:4:1, Eu/8:1:1, Eu/5:4:1 e $\mathrm{Cx} / 2: 7: 1$ mostraram tendências de apresentar as maiores médias de comprimento de inflorescência. 


\subsubsection{Número de ramos da inflorescência}

A observação dos resultados mostrou que, no número de ramos, os substratos comportaram-se de forma semelhante à variável maior diâmetro da inflorescência. Provavelmente esta semelhança indicou que, quanto maior o número de ramos, localizados principalmente na porção basal, maior foi o diâmetro da inflorescência.

Os substratos $\mathrm{Xa} / 2: 7: 1$ e Fc/8:1:1 diferindo estatisticamente das demais misturas, apresentaram as menores médias. Os outros substratos, em diferentes formulações, apresentaram médias que não diferiram significativamente entre si.

$\mathrm{O}$ substrato $\mathrm{Eu} / 2: 7: 1$ apresentou a tendência de mostrar a melhor média, seguidos de $\mathrm{Pi} / 5: 4: 1$ e Xa/5:4:1.

\subsubsection{Massa seca}

Foram consideradas como variáveis da massa seca a parte aérea vegetativa (folha, caule e escapo floral), inflorescência e sistema radicular.

Encontra-se na tabela 17 o resumo da análise de variância e teste F, com os graus de liberdade e quadrados médios para as variáveis de massa seca. Pelos resultados obtidos, verificou-se que houve efeito de tratamentos em todas as variáveis consideradas ao nível $\alpha<0,01$ de significância.

Para detectar diferenças entre os tratamentos, em todas as variáveis da massa seca, foi aplicado o teste de Tukey, ao nível $\alpha=0,05$ de significância, cujas médias encontram-se na tabela 18. 


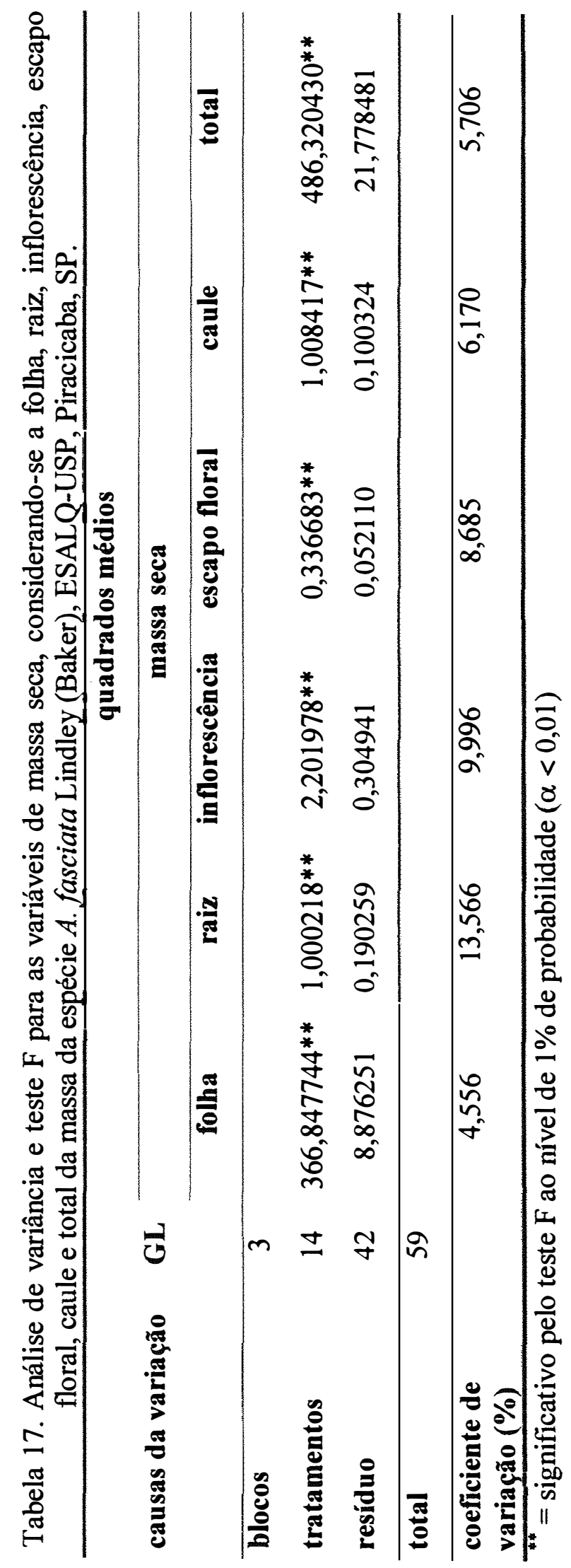

60 


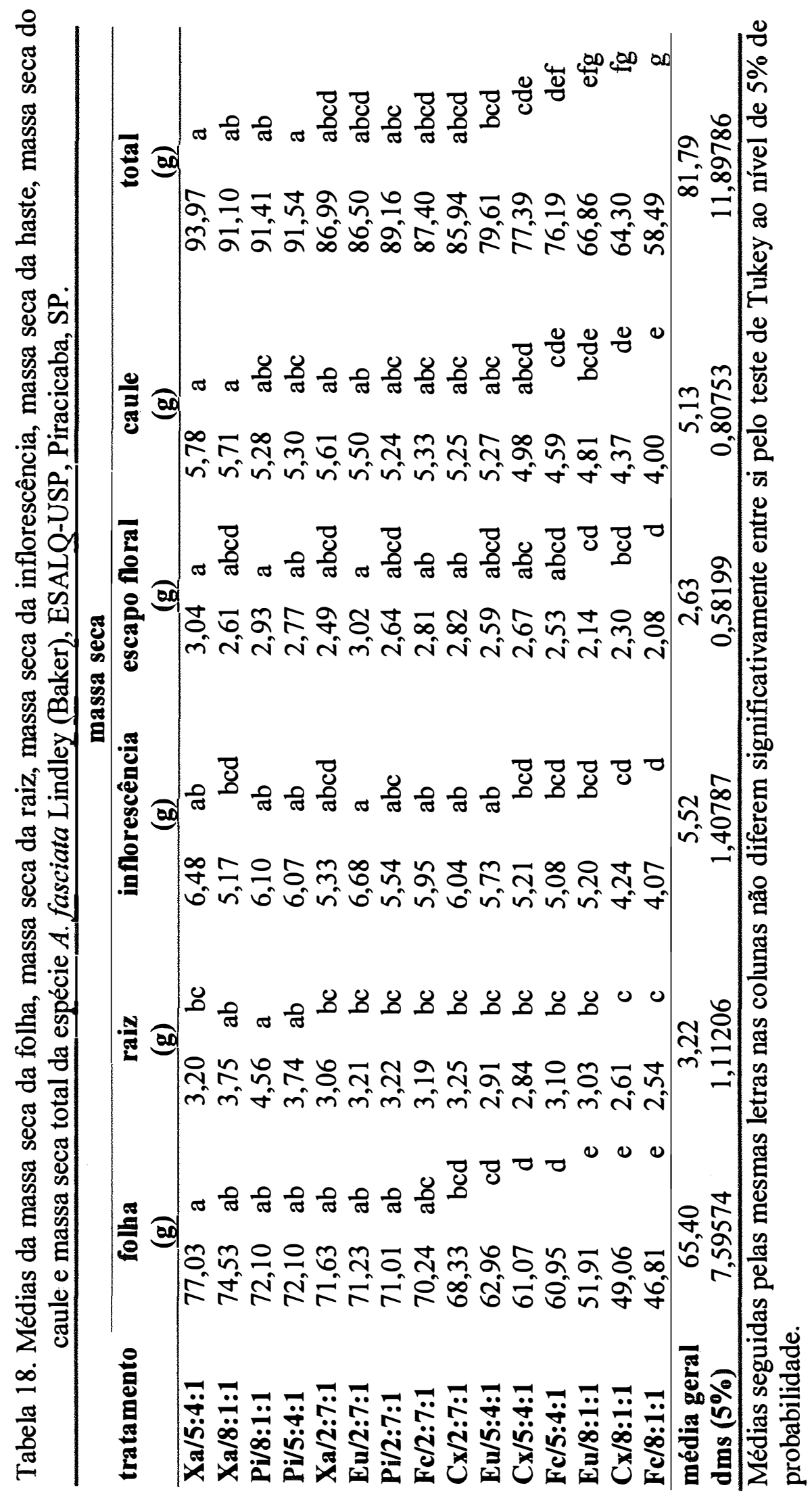




\subsubsection{Massa seca da folha}

As maiores médias para a produção de massa seca da folha foram proporcionadas pelos substratos contendo xaxim ou casca de Pinus, em todas as proporções utilizadas no experimento, e os substratos $\mathrm{Fc} / 2: 7: 1$ e $\mathrm{Eu} / 2: 7: 1$. As médias destes substratos não diferiram significativamente entre si. Nota-se que os substratos formulados com xaxim ou casca de Pinus apresentaram os mesmos resultados, independente das diferentes formulações, enquanto que os substratos compostos de fibra de coco ou casca de Eucalyptus, na proporção 2:7:1, mostraram que, provavelmente, a maior quantidade de turfa nas suas formulações compensou a menor proporção de fibra de coco ou casca de Eucalyptus.

Em uma posição intermediária de produção de massa seca, situaram-se os substratos que continham casca de Eucalyptus, coxim ou fibra de coco, todos na proporção 5:4:1, e o substrato $\mathrm{Cx} / 2: 7: 1$.

Mostraram as menores produções de massa seca foliar, os substratos constituídos de casca de Eucalyptus, coxim ou fibra de coco, na proporção 8:1:1. A menor proporção de turfa, pode ser a causa da menor produção.

Pode-se também inferir que o substrato $\mathrm{Xa} / 5: 4: 1$ apresentou a tendência de apresentar a maior média de produção de massa seca de folha.

\subsubsection{Massa seca do caule}

Os substratos formulados com xaxim ou casca de Pinus, em todas as proporções consideradas no experimento, e os substratos contendo casca de Eucalyptus, fibra de coco ou coxim, na proporção 2:7:1, bem como os substratos com casca de Eucalyptus ou coxim, na proporção 5:4:1, não diferiram significativamente entre si.

Verificou-se, também, que os substratos formulados com casca de Eucalyptus, coxim ou fibra de coco, na proporção $8: 1: 1$, e Fc/5:4:1 mostraram a menor produção de massa seca de caule, não diferindo significativamente entre si. A menor produção de 
massa seca de caule nestes substratos, deveu-se, provavelmente, à menor proporção de turfa, que foi de $10 \%$ em volume.

Pode-se também inferir que os substratos Xa/5:4:1 e Xa/8:1:1 mostraram a tendência de apresentar as melhores médias de produção de massa seca de caule.

\subsubsection{Massa seca do escapo floral}

Os resultados mostraram que as menores médias de produção de massa seca de escapo floral foram obtidas pelos substratos formulados com coxim, casca de Eucalyptus ou fibra de coco, na proporção 8:1:1. A menor eficiência destes substratos parece estar relacionada com a menor quantidade de turfa em suas formulações.

Os demais substratos apresentaram médias de massa seca de escapo floral que não diferindo significativamente entre si, foram formulados com xaxim ou casca de Pinus, em todas as proporções testadas, e casca de Eucalyptus, fibra de coco ou coxim, nas proporções 2:7:1 e 5:4:1.

Pode-se também inferir que os substratos Xa/5:4:1, Eu/2:7:1 e Pi/8:1:1 mostraram a tendência de apresentar as melhores médias de produção de massa seca de escapo floral.

\subsubsection{Massa seca da inflorescência}

As maiores médias de produção de massa de inflorescência e que não diferiram significativamente entre si, foram obtidas com os substratos formulados com casca de Pinus, em todas as proporções testadas, xaxim ou casca de Eucalyptus, nas proporções $2: 7: 1$ e $5: 4: 1$, fibra de coco ou coxim, na proporção $2: 7: 1$.

Nos substratos constituídos de coxim ou fibra de coco, na proporção 5:4:1, e casca de Eucalyptus ou xaxim, na proporção 8:1:1, mostraram que a produção de massa seca da inflorescência foi intermediária. 
Os substratos $\mathrm{Cx} / 8: 1: 1$ e Fc/8:1:1 mostraram as menores médias, indicando que os substratos formulados à base coxim ou fibra de coco com menor proporção de turfa, provavelmente, foram influenciados pela menor quantidade de turfa.

Pode-se, ainda, inferir que o substrato Eu/2:7:1 mostrou a tendência de apresentar a melhor média na variável massa seca da inflorescência.

\subsubsection{Massa seca da raiz}

Os substratos contendo casca de Pinus ou xaxim, na proporção 8:1:1, e Pi/5:4:1 apresentaram médias que não diferindo significativamente entre si, apresentaram os melhores resultados na produção de massa seca da raiz .

Seguiram-se em importância, numa posição intermediária, os substratos que continham em suas formulações xaxim, casca de Pinus, fibra de coco ou coxim, na proporção 2:7:1, xaxim, fibra de coco ou coxim, na proporção 5:4:1, e casca de Eucalyptus em todas as proporções.

A menor produção massa seca da raiz foi obtida com os substratos $\mathrm{Cx} / 8: 1: 1 \mathrm{e}$ $\mathrm{Fc} / 8: 1: 1$. Estes substratos continham turfa na proporção de 10\%, influindo, assim, provavelmente, na menor produção.

\subsubsection{Massa seca total}

Os resultados mostraram que os substratos formulados com xaxim ou casca de Pinus, em todas as proporções experimentadas, e os substratos constituídos de fibra de coco, casca de Eucalyptus ou coxim, na proporção 2:7:1, apresentaram as maiores médias de produção de massa seca total, não diferindo significativamente entre si.

Verificou-se que os substratos constituídos de casca de Eucalyptus, fibra de coco e coxim, todos formulados na proporção 5:4:1, apresentaram uma produção intermediária de massa seca total. 
Os substratos constituídos de casca de Eucalyptus, coxim e fibra de coco, na proporção 8:1:1, apresentaram a menor produção de massa seca total. Provavelmente, a menor produção esteja relacionada com a menor proporção de turfa. O substrato Fc/8:1:1 apresentou ainda baixa capacidade de campo, o que contribuiu para o menor rendimento da produção de massa seca.

Os substratos contendo xaxim e casca de Pinus, ambos nas proporções 5:4:1, mostraram a tendência de apresentar a melhor média de produção de massa total.

$\mathrm{O}$ registro fotográfico dos resultados acima relatados, pode ser observado nas plantas da figuras 09,10 e 11.

\subsubsection{Qualidade comercial e fixação da planta no substrato em vaso}

Para as variáveis qualidade comercial e fixação da planta no substrato em vaso, utilizando-se o critério de notas, observou-se, pela análise gráfica de resíduos, uma grande dependência entre as observações. Isto impossibilitou inferências através da análise de variância utilizando-se um modelo matemático, pois a falta de independência entre os resíduos viola uma das principais pressuposições para a realização da análise de variância. Além disto, estas variáveis, apesar de quantitativas (notas), são de origem discreta (nota $=1,2$, ou 3), não paramétricas e foram tratadas como dados categorizados, utilizando-se teste de independência. Assim, foram feitas tabelas de contingência para os cruzamentos das variáveis estudadas, e aplicada a estatística $\chi^{2}$ de Pearson para inferência sobre a independência ou não das variáveis cruzadas. 


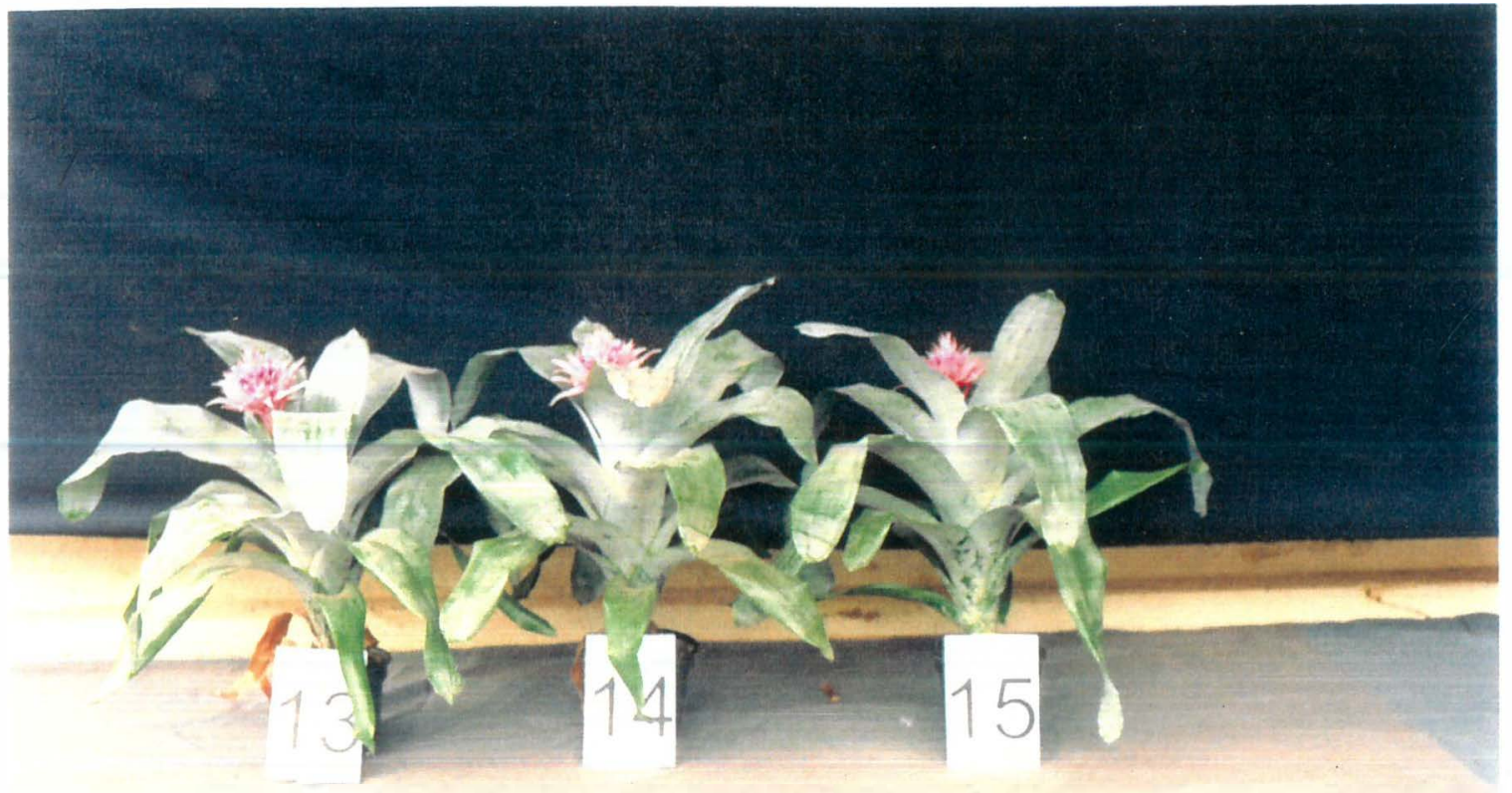

Figura 09. Espécimes de A. fasciata testados nos substratos formulados com xaxim, nas proporções 2:7:1 (13), 5:4:1 (14) e 8:1:1 (15), ESALQ-USP, Piracicaba, SP.

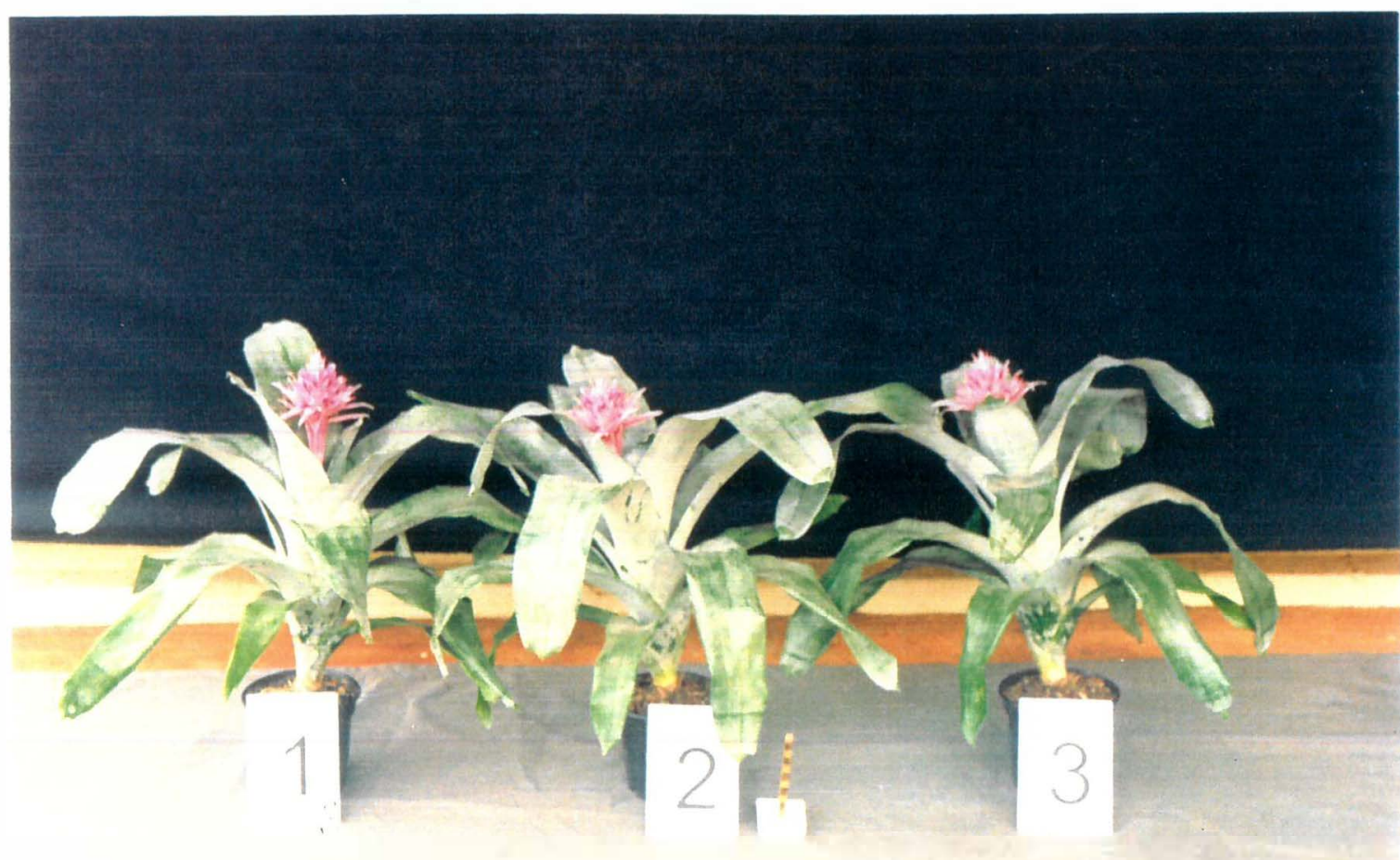

Figura 10. Espécimes de $A$. fasciata testados nos substratos formulados com casca de Pinus, nas proporções 2:7:1 (1), 5:4:1 (2) e 8:1:1 (3), ESALQ-USP, Piracicaba, SP. 


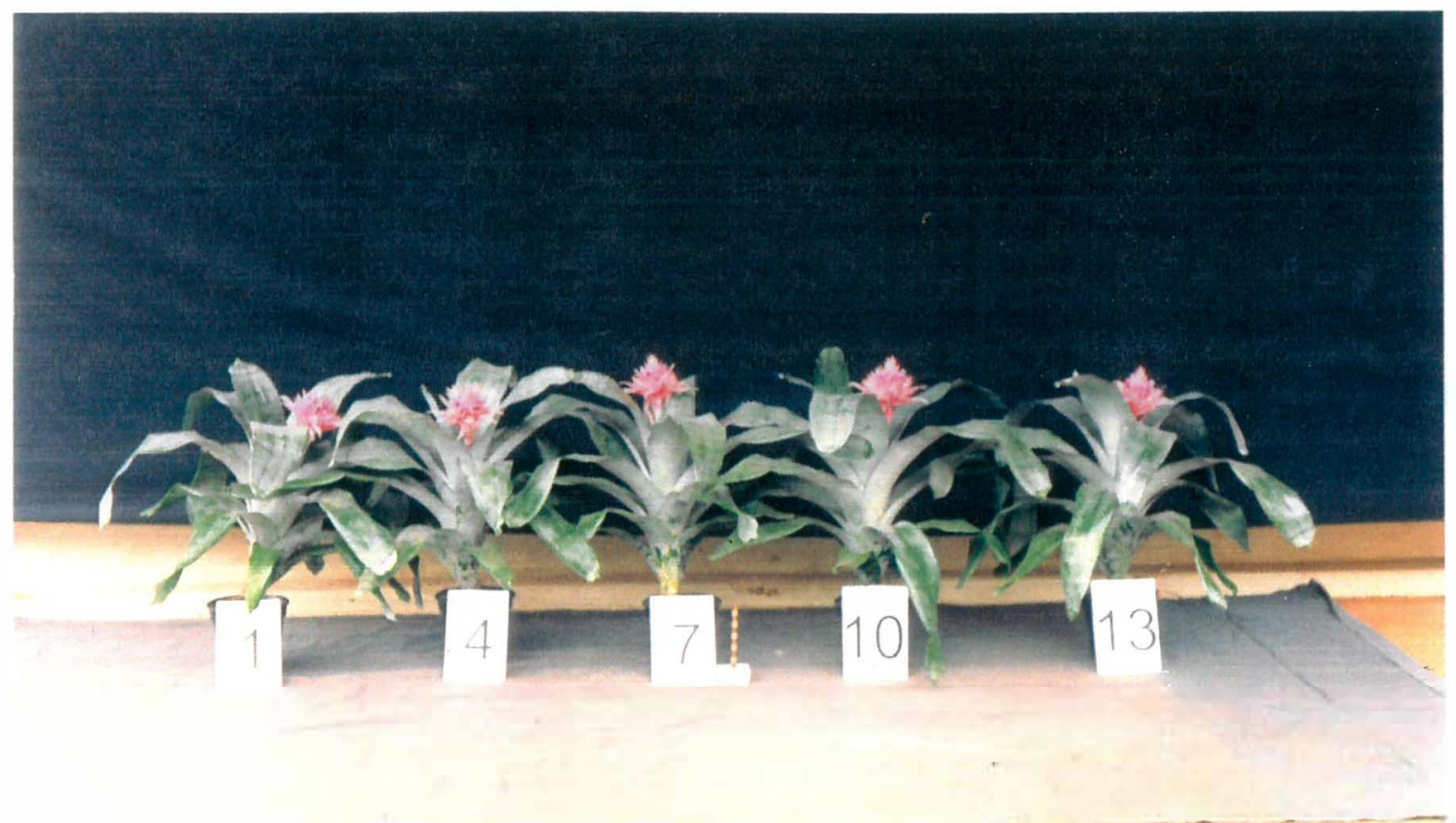

Figura 11. Espécimes de A. fasciata testados nos substratos formulados com casca de Pinus (1), casca de Eucalyptus (4), coxim (7), fibra de coco (10) e xaxim (13), na proporção 2:7:1, ESALQ-USP, Piracicaba, SP. 


\subsubsection{Qualidade comercial}

As freqüências observadas da qualidade comercial dos vasos, avaliadas através do critério de notas, e suas respectivas porcentagens estão dispostas na tabela 19.

Tabela 19. Freqüências observadas de notas 1, 2 e 3, e suas respectivas porcentagens na variável qualidade comercial da espécie A. fasciata Lindley (Baker), ESALQ-USP, Piracicaba, SP.

\begin{tabular}{|c|c|c|c|c|c|c|c|}
\hline \multirow[t]{2}{*}{ tratamentos } & \multicolumn{6}{|c|}{ nota de qualidade comercial } & \multirow[t]{2}{*}{ totais } \\
\hline & & 1 & & 2 & & 3 & \\
\hline $\mathrm{Pi} / 2: 7: 1$ & $\mathbf{0}$ & $(0,00 \%)$ & 4 & $(16,67 \%)$ & 20 & $(83,33 \%)$ & 24 \\
\hline Pi/5:4:1 & $\mathbf{0}$ & $(0,00 \%)$ & 1 & $(4,17 \%)$ & 23 & $(95,83 \%)$ & 24 \\
\hline $\mathrm{Pi} / 8: 1: 1$ & 1 & $(4,17 \%)$ & 4 & $(16,67 \%)$ & 19 & $(79,17 \%)$ & 24 \\
\hline Eu/2:7:1 & $\mathbf{0}$ & $(0,00 \%)$ & 4 & $(16,67 \%)$ & 20 & $(83,33 \%)$ & 24 \\
\hline Eu/5:4:1 & 4 & $(16,67 \%)$ & 10 & $(41,67 \%)$ & 10 & $(41,67 \%)$ & 24 \\
\hline $\mathrm{Eu} / 8: 1: 1$ & 10 & $(41,67 \%)$ & 10 & $(41,67 \%)$ & 4 & $(16,67 \%)$ & 24 \\
\hline $\mathrm{Cx} / 2: 7: 1$ & $\mathbf{0}$ & $(0,00 \%)$ & 5 & $(20,83 \%)$ & 19 & $(79,17 \%)$ & 24 \\
\hline$C x / 5: 4: 1$ & 3 & $(12,50 \%)$ & 12 & $(50,00 \%)$ & 9 & $(37,50 \%)$ & 24 \\
\hline $\mathrm{Cx} / 2: 7: 1$ & 13 & $(54,17 \%)$ & 11 & $(45,83 \%)$ & 0 & $(0,00 \%)$ & 24 \\
\hline Fc/2:7:1 & 0 & $(0,00 \%)$ & 3 & $(12,50 \%)$ & 21 & $(87,50 \%)$ & 24 \\
\hline Fc/5:4:1 & 0 & $(0,00 \%)$ & 14 & $(58,33 \%)$ & 10 & $(41,67 \%)$ & 24 \\
\hline Fc/8:1:1 & 13 & $(54,17 \%)$ & 11 & $(45,83 \%)$ & 0 & $(.0,00 \%)$ & 24 \\
\hline $\mathrm{Xa} / 2: 7: 1$ & 2 & $(8,33 \%)$ & 8 & $(33,33 \%)$ & 14 & $(58,33 \%)$ & 24 \\
\hline $\mathrm{Xa} / 5: 4: 1$ & $\mathbf{0}$ & $(0,00 \%)$ & 0 & $(0,00 \%)$ & 24 & $(100,00 \%)$ & 24 \\
\hline Xa/8:1:1 & 0 & $(0,00 \%)$ & 5 & $(20,83 \%)$ & 9 & $(79,17 \%)$ & 24 \\
\hline Totais & & 46 & & 102 & & 212 & 360 \\
\hline
\end{tabular}

$\mathrm{O}$ teste de qui-quadrado para verificar a independência entre os 15 tratamentos e as notas atribuídas, forneceu o valor de $\chi^{2}$ obs $=210,40$, significativo ao nível de $1 \%$, rejeitando a hipótese de independência, indicando que existe diferença entre os tratamentos com relação à variável qualidade comercial.

Procedeu-se, então, a comparação entre os tratamentos dois a dois, cujos resultados são apresentados na tabela 20 . 
Tabela 20. Resultados do teste de $\chi^{2}$ para a variável qualidade comercial, comparando os tratamentos dois a dois, na espécie $A$. fasciata Lindley (Baker), ESALQUSP, Piracicaba, SP.

\begin{tabular}{|c|c|c|c|c|}
\hline \multicolumn{3}{|c|}{ nota qualidade comercial } & \multirow{2}{*}{\multicolumn{2}{|c|}{ tratamento }} \\
\hline 3 & 2 & 1 & & \\
\hline 24 & 0 & 0 & $\mathrm{Xa} / 5: 4: 1 \mathrm{a}$ & \\
\hline 23 & 1 & 0 & $\mathrm{Pi} / 5: 4: 1 \mathrm{a}$ & \\
\hline 21 & 3 & 0 & $\mathrm{Fc} / 2: 7: 1 \mathrm{a}$ & \\
\hline 20 & 4 & 0 & $\mathrm{Pi} / 2: 7: 1$ & bc \\
\hline 20 & 4 & 0 & $\mathrm{Eu} / 2: 7: 1$ & bc \\
\hline 19 & 4 & 1 & $\mathrm{Pi} / 8: 1: 1$ & \\
\hline 19 & 5 & 0 & $\mathrm{Cx} / 2: 7: 1$ & bc \\
\hline 19 & 5 & 0 & $\mathrm{Xa} / 8: 1: 1$ & bc \\
\hline 14 & 8 & 2 & $\mathrm{Xa} / 2: 7: 1$ & $\mathrm{~cd}$ \\
\hline 10 & 10 & 4 & $\mathrm{Eu} / 5: 4: 1$ & de \\
\hline 10 & 14 & 0 & $\mathrm{Fc} / 5: 4: 1$ & $\mathrm{~d}$ \\
\hline 9 & 12 & 3 & $\mathrm{Cx} / 5: 4: 1$ & de \\
\hline 4 & 10 & 10 & $\mathrm{Eu} / 8: 1: 1$ & ef \\
\hline 0 & 11 & 13 & $\mathrm{Cx}: 8: 1: 1$ & $\mathrm{f}$ \\
\hline 0 & 11 & 13 & $\mathrm{Fc} / 8: 1: 1$ & $\mathrm{f}$ \\
\hline
\end{tabular}

Tratamentos com letras iguais não diferem, pelo teste de $\chi^{2}$, ao nível de $5 \%$ de significância.

Os resultados mostraram que se destacaram no aspecto da qualidade comercial os substratos Xa/5:4:1, Pi/5:4:1, Fc/2:7:1 e Pi/8:1:1.

A seguir vieram os substratos formulados com casca de Pinus ou Eucalyptus ou coxim, na proporção 2:7:1, e Xa/8:1:1.

Numa posição intermediária apresentaram-se os substratos com casca de Eucalyptus, fibra de coco ou coxim, na proporção 5:4:1.

Dos resultados observados nos três parágrafos anteriores, podemos inferir ainda que os substratos formulados com xaxim e casca de Pinus, em todas as proporções, e os substratos com casca de Eucalyptus, fibra de coco e coxim, na proporção 2:7:1 e 5:4:1, apresentaram maior freqüência de notas 3 e 2 .

Os substratos contendo casca de Eucalyptus, coxim ou fibra de coco, todos na proporção 8:1:1, mostraram os piores resultados no aspecto qualidade comercial. Notouse que estes substratos foram formulados com maior proporção de casca de Eucalyptus, coxim ou fibra de coco e consequentemente menor quantidade de turfa. 


\subsubsection{Fixação da planta no substrato em vaso}

As freqüências observadas de fixação da planta no substrato em vaso, avaliadas através do critério de notas, e suas respectivas porcentagens estão dispostas na tabela 21.

Tabela 21. Freqüências observadas de notas 1,2 e 3, e suas respectivas porcentagens na variável fixação da planta no substrato em vaso da espécie $A$. fasciata Lindley (Baker), ESALQ-USP, Piracicaba, SP.

\begin{tabular}{|c|c|c|c|c|c|c|c|}
\hline tratamento & & notas & fix: & ção da pla & $10 \mathrm{st}$ & bstrato & totais \\
\hline $\mathrm{Pi} / 2: 7: 1$ & $\mathbf{0}$ & $(0,00 \%)$ & 4 & $(16,67 \%)$ & 20 & $(83,33 \%)$ & 24 \\
\hline Pi/5:4:1 & 1 & $(4,17 \%)$ & 4 & $(16,67 \%)$ & 19 & $(79,17 \%)$ & 24 \\
\hline Pi/8:1:1 & 3 & $(12,50 \%)$ & 4 & $(16,67 \%)$ & 17 & $(70,83 \%)$ & 24 \\
\hline Eu/2:7:1 & 1 & $(4,17 \%)$ & 7 & $(29,17 \%)$ & 16 & $(66,67 \%)$ & 24 \\
\hline Eu/5:4:1 & 10 & $(41,67 \%)$ & 10 & $(41,67 \%)$ & 4 & $(16,67 \%)$ & 24 \\
\hline Eu/8:1:1 & 21 & $(87,50 \%)$ & 1 & $(4,17 \%)$ & 2 & $(8,33 \%)$ & 24 \\
\hline $\mathrm{Cx} / 2: 7: 1$ & 2 & $(8,33 \%)$ & 2 & $(8,33 \%)$ & 20 & $(83,33 \%)$ & 24 \\
\hline Cx/5:4:1 & 2 & $(8,33 \%)$ & 6 & $(25,00 \%)$ & 16 & $(66,67 \%)$ & 24 \\
\hline$C x / 2: 7: 1$ & 1 & $(4,17 \%)$ & 3 & $(12,50 \%)$ & 20 & $(83,33 \%)$ & 24 \\
\hline Fc/2:7:1 & 0 & $(0,00 \%)$ & 4 & $(16,67 \%)$ & 20 & $(83,33 \%)$ & 24 \\
\hline $\mathrm{Fc} / 5: 4: 1$ & 8 & $(33,33 \%)$ & 10 & $(41,67 \%)$ & 6 & $(25,00 \%)$ & 24 \\
\hline Fc/8:1:1 & 14 & $(58,33 \%)$ & 10 & $(41,67 \%)$ & 0 & $(0,00 \%)$ & 24 \\
\hline $\mathrm{Xa} / 2: 7: 1$ & 2 & $(8,33 \%)$ & 1 & $(4,17 \%)$ & 21 & $(87,50 \%)$ & 24 \\
\hline $\mathrm{Xa} / 5: 4: 1$ & 2 & $(8,33 \%)$ & 1 & $(4,17 \%)$ & 21 & $(87,50 \%)$ & 24 \\
\hline $\mathrm{Xa} / 8: 1: 1$ & 2 & $(8,33 \%)$ & 5 & $(20,83 \%)$ & 17 & $(70,83 \%)$ & 24 \\
\hline Totais & & 69 & & 72 & & 219 & 360 \\
\hline
\end{tabular}

Para verificar a independência entre os 15 tratamentos e as notas atribuídas, aplicou-se o teste de qui-quadrado que forneceu o valor de $\chi^{2}$ obs $=196,39$, significativo ao nível de $1 \%$. Este resultado rejeitou a hipótese de independência, indicando que existe diferença entre os tratamentos com relação à variável fixação da planta no substrato em vaso.

Procedeu-se, então, a comparação entre os tratamentos dois a dois, cujos resultados são apresentados na tabela 22 . 
Tabela 22. Resultados do teste de $\chi^{2}$ para a variável notas de fixação da planta no vaso, comparando os ratamentos dois a dois, na espécie A. fasciata Lindley (Baker), ESALQ-USP, Piracicaba, SP.

\begin{tabular}{|c|c|c|c|}
\hline \multicolumn{3}{|c|}{ notas de fixação } & \multirow[t]{2}{*}{ tratamento } \\
\hline 3 & 2 & 1 & \\
\hline 21 & 1 & 2 & $\mathrm{Xa} / 2: 7: 1 \mathrm{a}$ \\
\hline 21 & 1 & 2 & $\mathrm{Xa} / 5: 4: 1 \mathrm{a}$ \\
\hline 20 & 4 & 0 & $\mathrm{Pi} / 2: 7: 1 \mathrm{a}$ \\
\hline 20 & 4 & 0 & $\mathrm{Fc} / 2: 7: 1 \mathrm{a}$ \\
\hline 20 & 2 & 2 & $\mathrm{Cx} / 2: 7: 1 \mathrm{a}$ \\
\hline 20 & 3 & 1 & $\mathrm{Cx} / 8: 1: 1 \mathrm{a}$ \\
\hline 19 & 4 & 1 & $\mathrm{Pi} / 5: 4: 1 \mathrm{a}$ \\
\hline 17 & 5 & 2 & $\mathrm{Xa} / 8: 1: 1 \mathrm{a}$ \\
\hline 17 & 4 & 3 & $\mathrm{Pi} / 8: 1: 1 \mathrm{a}$ \\
\hline 16 & 7 & 1 & $\mathrm{Eu} / 2: 7: 1 \mathrm{a}$ \\
\hline 16 & 6 & 2 & $\mathrm{Cx} / 5: 4: 1 \mathrm{a}$ \\
\hline 6 & 10 & 8 & $\mathrm{Fc} / 5: 4: 1 \quad \mathrm{~b}$ \\
\hline 4 & 10 & 10 & $\mathrm{Eu} / 5: 4: 1 \quad$ bc \\
\hline 2 & 1 & 21 & $\mathrm{Eu} / 8: 1: 1 \quad \mathrm{~d}$ \\
\hline 0 & 10 & 14 & $\mathrm{Fc} / 8: 1: 1 \quad \mathrm{c}$ \\
\hline
\end{tabular}

Tratamentos com letras iguais não diferem pelo teste de $\chi^{2}$ ao nível de $5 \%$ de significância.

Os resultados mostraram que os substratos formulados com xaxim, casca de Pinus ou coxim, em qualquer das proporções consideradas no experimento, Eu/2:7:1 e $\mathrm{Fc} / 2: 7: 1$ apresentaram os melhores resultados, não diferindo significativamente entre si, com as plantas firmemente enraizadas e fixas nos substratos contidos pelos vasos.

É importante ressaltar que mesmo diminuindo a quantidade de xaxim, casca de Pinus ou coxim, e conseqüente aumento na proporção de turfa, os substratos considerados apresentaram a mesma eficiência na fixação da planta no substrato. Da mesma forma, os substratos contendo casca de Eucalyptus ou fibra de coco, na proporção 2:7:1, foram efetivos na fixação da planta.

Os substratos com os piores resultados na fixação da planta foram $\mathrm{Fc} / 5: 4: 1$, $\mathrm{Eu} / 5: 4: 1, \mathrm{Fc} / 8: 1: 1$ e Eu/8:1:1, na ordem decrescente.

Dentre todos os substratos, aquele que se mostrou menos promissor na fixação da planta foi Eu/8:1:1. Provavelmente, o substrato, por conter $80 \%$ em volume de casca de Eucalyptus, apresentou modificações na estrutura física, prejudicando a formação de 
corpo suficientemente rígido para fixar as raízes com firmeza, pois ao final do experimento, com o aumento da massa fresca, principalmente da inflorescência, o centro da gravidade da planta foi deslocado, exigindo, assim, maior rigidez do substrato. Mudanças de estrutura também foram relatadas por DEMATTÊ (1992), que utilizou casca de $E$. grandis pura no cultivo de Dendrobium nobile Lindl., principalmente pelas alterações de estrutura que prejudicaram sua porosidade, já no final de primeiro ano de cultivo.

A formação de corpo e firmeza pelos substratos é uma das características de importância numa mistura ideal, segundo as observações de MINAMI (1995). Isto explicaria um dos piores resultados nesta variável, para o substrato $\mathrm{Fc} / 8: 1: 1$, que não teve formação de corpo e firmeza suficiente parar suportar a planta quando adulta, após o florescimento. 


\section{CONCLUSÕES}

Nas condições em que foi conduzido o experimento, concluiu-se que:

- Os substratos formulados com xaxim ou casca de Pinus, nas proporções 2:7:1, 5:4:1 e 8:1:1, e casca de Eucalyptus, fibra de coco ou coxim, na proporção 2:7:1, foram as misturas que apresentaram os melhores resultados.

- Os substratos formulados com casca de Eucalyptus, fibra de coco ou coxim, na proporção 8:1:1, apresentaram os piores resultados.

- Casca de Pinus, nas proporções 2:7:1, 5:4:1 e 8:1:1, casca de Eucalyptus, fibra de coco ou coxim, na proporção 2:7:1, são os substratos alternativos que poderiam substituir com eficácia as misturas que contém xaxim, nas proporções 2:7:1, 5:4:1 e $8: 1: 1$. 


\section{REFERÊNCIAS BIBLIOGRÁFICAS}

ARRUDA, S.T.; OLIVETTE, M.P. de; CASTRO, C.E.F. de. Diagnóstico da floricultura do Estado de São Paulo. Revista Brasileira de Horticultura Ornamental, v.2, n.2, p.1-18, 1996.

BALLESTER-OLMOS, J.F. Substratos para el cultivo de plantas omamentales. Hojas Divulgadoras, n. 11, p. 1-44, nov. 1992.

BANZATTO, D.A.; KRONKA, S. N. Experimentação agrícola. 3. ed. Jaboticabal: Funep, 1995. 247p.

BELLÉ, S. Escolha do substrato. In: Kämpt, A.N. Manutenção de plantas ornamentais para interiores. Porto Alegre: Rígel, 1995. cap. 4, p. 31-37.

BOERTJE, G.A. Physical laboratory analyses of potting composts. Acta Horticulturae, n. 150, p. 47-50, 1983.

BRASIL. Leis, decretos, etc. Portaria no 06-N de 15 de jan. 1992. Diário Oficial, 06 abr. 1992.

BUNT, A.C. Modern potting composts. London: George Allen \& Unwin, 1976. $277 \mathrm{p}$. 
D'ANDRÉA, J.C. Substratos e fertilizantes para cultivo de Aechmea fasciata Bak. (Bromeliaceae). Jaboticabal, 1997. 49p. Trabalho (Graduação) - Faculdade de Ciências Agrárias e Veterinárias , Campus de Jaboticabal, Universidade Estadual Paulista "Júlio de Mesquita Filho".

DEMATTÊ, M.E.S.P. Substratos vegetais para cultivo de orquídeas epífitas. Jaboticabal, 1992. 117p. Tese (livre docência) - Faculdade de Ciências Agrárias e Veterinárias, Campus de Jaboticabal, Universidade Estadual Paulista "Júlio de Mesquita Filho".

DEUlOFEU, C.; AGUILA-VILA, J. Pine bark as substrate for Primula and Petunia. Acta Horticulturae, n. 150, p. 263-70, 1983.

DIMMIT, M.A. Bromeliads: a cultural manual. Oregon: The Bromeliad Society, 1992. 42p.

DIRR, M.A.; HEUSER JR., C.W. The reference manual of woody plant propagation: from seed to tissue culture. Athens: Varsit Press, 1987. 239p.

FOSTER, M.B. Bromeliads: a cultural handbook. Orlando: The Bromeliad Society, 1953, 64p.

FRETZ, T.A.; READ, P.E.; PEELE, M.C. Plant propagation lab manual. Minneapolis, Burges Publishing, 1979. 317p.

GALLANGER, P.A. Peat in protected cropping. In: ROBINSON, D.W.; LAMB, J.G.D. Peat in horticultural. London: Academic Press, 1975. v.3, cap.10, p.133145 . 
GONÇALVES, A.L. Características do substrato In: CASTRO, C.E.F. de; ANGELIS, B.L.D. de; MOURA, L.P.P. de, coord. Maringá: s. ed., 1992. cap. 3, p. 44-52.

HARTMANN, H.T.; KESTER, D.E. Plant propagation: principles and practices. 7.ed. New Jersey: Prentice-Hall, 1983. 727p.

HOAGLIN, D.C.; MOSTELLER, F.: TUKEY, J.W. Análise exploratória dos dados. Lisboa: Editora Salamandra, 1992. cap. 4. p. 97-128: Transformação robusta.

KÄMPF, A.N. Bromélias. In: CASTRO, C.E.F. de; ANGELIS, B.L.D. de; MOURA, L.P.P. de, coord. Manual de floricultura. Maringá: s. ed., 1992a. cap. 7, p. 201211.

KÄMPF, A.N. Substratos para floricultura. In: CASTRO, C.E.F. de; ANGELIS, B.L.D. de; MOURA, L.P.P. de, coord. Manual de floricultura. Maringá: s. ed., 1992b. cap. 3, p. 32-52.

KÄMPF, A.N. Leaf a fertilization of Aechmea fasciata (Lindley) Baker. Bromélia, v. 1, n. 4, p. 16-20, 1994.

KAVANAGH, T.; HERLIHY, M. Microbiological aspects. In: ROBINSON, D.W.; LAMB, J.G.D. Peat in horticultural. London: Academic Press, 1975. v. 3, cap. 3, p. 39.

LEME, E.M.C. Aechmea fasciata, o símbolo da Sociedade Brasileira de Bromélias. Bromélia, v. 1, n. 1, p. 34-35, 1994.

LORENZI, H.; SOUZA, H.M. de. Plantas ornamentais no Brasil: arbustivas, herbáceas e trepadeiras. Nova Odessa: Plantarum, 1995. 719p. 
MACDONALD, B. Practical woody plant propagation for nursery growers. Portland: Timber Press, 1993. 669p.

MATSUNAGA, M. Floricultura como alternativa econômica na agricultura. Informações Econômicas, v. 25, n.11, p. 94-98, nov. 1995.

MEEROW, A.W. Growth of two subtropical omamentals using coir (coconut mesocarp pith) as a peat substitute. HortScience, v. 29, n. 12, p. 1484-1486, 1994.

MELE-GRAU. E.; MESSEGUER-PEYPOCH, J. Estudio de algunos aspectos del cultivo de Aechmea fasciata (Back.). Anales del Instituto Nacional de Investigaciones Agrárias, n. 12, p. 133-155, 1980.

MINAMI, K. Utilização da vermiculita na floricultura e paisagismo. In: CONGRESSO DA SOCIEDADE BRASILEIRA DE FLORICULTURA E PLANTAS ORNAMENTAIS, 3, Salvador, 1982. Anais. Campinas: Fundação Cargill, 1986. p. 259-267.

MINAMI, K. Produção de mudas em recipiente. In: MINAMI, K. Produção de mudas de alta qualidade em horticultura. São Paulo: Fundação Salim Farah Maluf, 1995. cap. 13, p. 85-101.

NOGUEIRA, M.C.S. Estatística experimental aplicada à experimentação agrícola. Piracicaba: ESALQ, 1994. 204p.

OLIVEIRA, L.L.C.; CORAL, R.P.S.P.; SILVA NETTO, A.F. da; KISHI, H.; RAMOS, J.M.A. Cultura do Coco no Pará. Belém: IDESP, 1975. 86p.

OLYMPIOS, C.M. Soiless media under protected cultivation rockwool, peat, perlite and other substrates. Acta Horticulturae, n. 323, p. 215-234, 1992. 
PAGES-PALLARES, M.; MATALLANA-GONZALEZ, A.M. Caracterizacion de las propriedades físicas, en los substratos empleados en horticultura omamental. Comunicaciones I.N.I.A.. Série Produção Agrícola, n. 61, p. 1-32, 1984.

REITZ, R. Bromeliáceas e malária-bromélia endêmica. Itajaí: Herbário Barbosa Rodrigues, 1983. 808p.

SAMYN, G.; THOMAS, F. The belgians and bromeliads: part I, the 19th century: Belgium becomes an horticultural nation. Bromélia, v.1, n.1, p.3-8, 1994.

SANTOS, A. A. dos Dicksonia sellowiana (Presl.) Hook p. 47-48. In: SOCIEDADE BOTÂNICA DO BRASIL. Centuria plantarum brasiliensium exstinionis minitata. São Paulo, 1992. 167p.

SHEARD, G.F. Loamless substrates for use in containers and as unit products. In: ROBINSON, D.W.; LAMB, J.G.D. Peat in horticultural. London: Academic Press, 1975. v. 3, cap. 9, p. 119-132.

SILVA, R.S.; GONÇALVES, A.R.; FERNANDES, L.A. (Org.) Relatório do workshop sobre conservação e manejo de Dicksonia sellowiana. Brasilia: IBAMA, 1997. 37p.

SMITH, L.B. The Bromeliaceae of Brazil. Smithsonian Miscellaneous Collections, v.126, n.1, p.216, Sep. 1955.

VERDONCK, O. Utilizacion of pine bark compost in horticulture. Compost Science, n.21, n.1, p.22-23, jan./feb. 1980.

VERDONCK, O. New developments in the use of graded perlite in horticultural substrates. Acta Horticulturae, n. 150, p. 575-581, 1983. 
VITARI, M. Bromélia: produção e proteção. Ecologia e Desenvolvimento, v. 3, n. 37, p. 15-17, mar. 1994.

WALL, B. Bromeliads. London: Cassel Educational, 1988. 63p.

WHTCOMB, C.E. Plant production in containers. Oklahoma: Lacebark Publ., 1984. $638 \mathrm{p}$.

WILLIAMS, B; HODGSON, I. Growing bromeliads. London: Christopher Helm, 1990. 150p.

ZIMMER, K. Bromeliaceae (Omamentals). In: HALEVY, A.H. CRC Handbook of Flowering. Boca Raton: CRC Press, 1985. v. 2, p.78-81. 